\title{
AVALIAÇÃO DA SUSCEPTIBILIDADE TÉRMICA E DO EFEITO DAS CONDIÇÕES AMBIENTAIS NO ENRIJECIMENTO DE MISTURAS ASFÁLTICAS DENSAS À LUZ DE SEUS COMPORTAMENTOS RESILIENTES
}

Dissertação apresentada à Escola de Engenharia de São Carlos, da Universidade de São Paulo, como parte dos requisitos para a obtenção do Título de Mestre em Engenharia Civil: Infra-estrutura de Transportes.

ORIENTADOR: Prof. Dr. Glauco Túlio Pessa Fabbri

São Carlos

2007 
AUTORIZO A REPRODUÇÃO E DIVULGAÇÃO TOTAL OU PARCIAL DESTE TRABALHO, POR QUALQUER MEIO CONVENCIONAL OU ELETRÔNICO, PARA FINS DE ESTUDO E PESQUISA, DESDE QUE CITADA A FONTE.

Ficha catalográfica preparada pela Seção de Tratamento da Informação do Serviço de Biblioteca - EESC/USP

Gigante, Antonio Carlos
G459a Avaliação da susceptibilidade térmica e do efeito das condições ambientais no enrijecimento de misturas asfálticas densas à luz de seus comportamentos resilientes / Antonio Carlos Gigante ; orientador Glauco Túlio Pessa Fabbri. -- São Carlos, 2007.

Dissertação (Mestrado-Programa de Pós-Graduação em Engenharia de Transportes e Área de Concentração em Infra-Estrutura de Transportes) -- Escola de Engenharia de São Carlos da Universidade de São Paulo, 2007.

1. Pavimentação. 2. Misturas asfálticas. 3. Asfalto.

4. Módulo de resiliência. 5. Misturas asfálticas com cal. 6. Condições ambientais. I. Título. 


Dedico este Trabalho: À minha esposa Vilma e às minhas filhas Ana Carolina e Ana Marina. Aos meus pais José e Maria (in memorian). 

Ao Prof. Dr. Glauco Túlio Pessa Fabbri, pela orientação, amizade ajuda e paciência inesgotável no desenvolvimento desse trabalho;

À Ana Paula Furlan, pela imensurável ajuda e dedicação, nunca me deixando esmorecer;

Ao Departamento de Transportes STT, pela oportunidade;

Aos Professores do Departamento, pela dedicação e paciência nos ensinamentos;

Aos Técnicos Paulo Toyama e João Domingos, pela ajuda, incentivo e amizade;

Aos amigos Carlos (Toco) e Vicente Daló pela ajuda na solução de problemas e pela amizade;

Aos amigos das secretarias do Departamento e da Pós-Graduação, Sueli, Magali, Alexandre, Heloisa e Beth pela colaboração e amizade;

À equipe do consórcio Ana P. Furlan e Fábio Iwanaga, por todo o tempo que trabalhamos juntos, pela amizade e dedicação;

À Betunel, em nome de Rômulo Constantino, pela execução dos ensaios e pelos ensinamentos;

Aos amigos que deram o primeiro incentivo, Marcus Seraphico (Marcão), Carlos Prado (Sombra) e Heliana Fontenele;

Aos amigos Matheus Araujo, Jesner Sereni, Francis Kakuda, Adalberto Faxina, Marcelo Takeda, Bruno Bertoncini e Marcos Botene que nas necessidades souberam socorrer;

À antiga equipe de trabalho André Mugayar, Jisela Greco e Paulo César (PC) pela colaboração;

A todos os alunos da Pós-Graduação do Departamento de Transportes, pela amizade e incentivo;

Ao Prof. Lazaro Zuqueti, do Departamento de Geotecnia, pelos ensinamentos sobre rochas;

À Engenharia e Comércio Bandeirantes Ltda., Pedreira São Roque e Pedreira São Jerônimo, pelo fornecimento dos Agregados utilizados nessa pesquisa;

Ao Centro de Pesquisa e Desenvolvimento (CENPES) da Petrobrás, pelo fornecimento dos materiais asfálticos utilizados nessa pesquisa;

A todos aqueles que, direta ou indiretamente, colaboraram. 



\section{GIGANTE, A.C. Avaliação da susceptibilidade térmica e do efeito das condições} ambientais no enrijecimento de misturas asfálticas densas à luz de seus comportamentos resiliente. 2007. 169 f. Dissertação (Mestrado) - Escola de Engenharia de São Carlos, Universidade de São Paulo, São Carlos, 2007.

Este trabalho teve com objetivo avaliar o módulo de resiliência de misturas asfálticas densas sob duas condições. A primeira foi o estudo dos efeitos do enrijecimento de misturas asfálticas densas em condições ambientais diferentes (cinco condições) que são: AAAL (Ao Ar e à Luz), AASL (Ao Ar e Sem Luz), AVAL (baixa pressão atmosférica e à Luz), AVSL (baixa pressão atmosférica e sem Luz) e CLIMA (ao clima e intempéries), tendo sido utilizados para este experimento CAP 20, centro da faixa C do DNER como distribuição granulométrica e preparados segundo a AASHTO PP2. Neste estudo concluiu-se que não houve efeito significativo da exposição da luz artificial nas condições AL e SL, assim como não houve, também, efeito significativo na variação do módulo de resiliência nas condições de exposição ou não ao ar (AV e AA); nas demais condições houve melhora significativa nos resultados. Na segunda parte foram avaliados os efeitos de alguns fatores na susceptibilidade térmica de misturas asfálticas densas: tipo de agregado (basalto, gabro e granito), tipo de asfalto (CAP 20 e CAP 40), teor de asfalto (5\%, 5,5\% e 6\%), presença de aditivo (com e sem cal) e temperaturas de ensaio $\left(10^{\circ} \mathrm{C}, 25^{\circ} \mathrm{C}\right.$ e $\left.40^{\circ} \mathrm{C}\right)$. Todos os corpos-de-prova foram preparados segundo procedimento da AASHTO PP2. Na segunda parte do experimento, concluiu-se que o CAP 40 produziu valores médios de Vv superiores aos do CAP 20, as misturas com teor de 5,5\% apresentaram maior resistência à tração a $25^{\circ} \mathrm{C}$, o módulo de resiliência e a relação MR/RT diminuem com o aumento do teor de CAP.

Palavras-chave: Misturas asfálticas. Pavimento. Asfalto. Módulo de resiliência. Misturas asfálticas com cal. Condições ambientais. 
GIGANTE, A.C. Evaluation of the thermal susceptibility and the effect of the environmental conditions in the hardening of dense-graded hot-mix asphalt to the light of their resilient behavior. 2007. 169 p. Master thesis (Mastering) - Sao Carlos Engineering School, University of Sao Paulo, Sao Carlos, 2007.

This work intended to evaluate the resilient modulus of dense-graded hot-mix asphalt under two conditions. The first condition comprehends a study of the hardening effects of densegraded hot mix asphalt submitted to five environmental conditions: AAAL (air and artificial light), AASL (air and no artificial light), AVAL (low atmospheric pressure and artificial light), AVSL (low atmospheric pressure and no artificial light) and CLIMA (exposition to intemperism). In this phase, it was used an AC-20 asphalt binder and DNER middle band " $\mathrm{C}$ " as aggregate's particles size distribution. Specimens were prepared according to AASHTO PP2. Based on the results of the first part of the experiment, it was concluded that there was no significant effect of the artificial light exposition on AL and SL conditions, as well as on the variation of resilient modulus under air conditions (AV and AA). The other conditions presented better performance results. The second part of the experiment aimed to evaluating the effect of some factors in the thermal susceptibility of dense-graded HMA, that are: aggregate type (basalt, gabbro, granite), asphalt type (AC-20 and AC-40), binder content $(5,0 \%, 5,5 \%$ and $6,0 \%)$, presence of additive (with or without lime) and test temperature $\left(10^{\circ} \mathrm{C}, 25^{\circ} \mathrm{C}\right.$ and $\left.40^{\circ} \mathrm{C}\right)$. As in the first part of the experiment, all specimens were prepared according to AASHTO PP2. Results of the second part of the experiment led to the following conclusions: mixtures using AC-40 showed average air voids higher than mixtures using AC20 , mixtures with a binder content of 5,5\% showed the highest values of tensile strength, at $25^{\circ} \mathrm{C}$, the resilient modulus and the MR/RT ratio reduce when binder content increases.

Keywords: Hot mix asphalt mixes. Pavement. Asphalt. Resilient modulus. Hot-mix asphalt with lime. Environmental conditions. 
Figura 2.1: Configurações dos carregamentos utilizados em ensaio de MR (BARKSDALE et al., 1997).

Figura 2.2: Comportamento de uma mistura asfáltica nas primeiras solicitações de um ensaio de módulo de resiliência (FURLAN, 2006a) 35

Figura 2.3: Deformações resilientes total e instantânea pela AASHTO (FURLAN, 2006) . 39

Figura 2.4: Curva de deformação para um ciclo de carregamento (FURLAN, 2006) ..........40

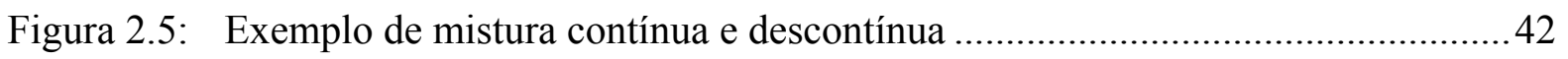

Figura 3.1: Procedimentos de lavagem e secagem dos agregados........................................ 77

Figura 3.2: Distribuições granulométricas dos diferentes agregados enquadrados na faixa $\mathrm{C}$

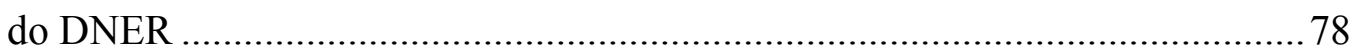

Figura 3.3: Viscosidade Saybolt-Furol versus temperatura para o CAP 20 ......................... 81

Figura 3.4: Viscosidade Saybolt-Furol versus temperatura para o CAP 40 .......................... 81

Figura 3.5: Equipamento adaptado para preparação de misturas asfálticas......................... 83

Figura 3.6: Esquema de equipamento para determinação do módulo de resiliência ............89

Figura 4.1: Efeito do fator "iluminação" na variação do MR ao longo do tempo para condições ambientais "ao ar" ........................................................................ 95

Figura 4.2: Efeito de fator "iluminação" na variação do MR ao longo do tempo para condições ambientais "ao vácuo" .....................................................................96

Figura 4.3: Variação do MR ao longo do tempo para a condição ambiental "CLIMA" ......97

Figura 4.4: Efeito do fator condição ambiental nos valores médios dos módulos de resiliência .98

Figura 4.5: Efeito do tempo de exposição nos valores médios dos módulos de resiliência 99

Figura 4.6: Volumes de vazios em função do teor e tipo de asfalto e presença de cal para o agregado tipo basalto 101

Figura 4.7: Volumes de vazios em função do teor e tipo de asfalto e presença de cal para o agregado tipo granito

Figura 4.8: Volumes de vazios em função do teor e tipo de asfalto e presença de cal para o agregado tipo gabro 102

Figura 4.9: Variação da resistência à tração em função do teor de asfalto ou do volume de vazios para o agregado basalto .104 
Figura 4.10: Variação da resistência à tração em função do teor de asfalto ou do volume de vazios para o agregado granito. 104

Figura 4.11: Variação da resistência à tração em função do teor de asfalto ou do volume de vazios para o agregado gabro 104

Figura 4.12: Variação do módulo de resiliência em função do teor de asfalto para os diferentes tipos de asfaltos e temperaturas de ensaio para o agregado basalto 106

Figura 4.13: Variação do módulo de resiliência em função do teor de asfalto para os diferentes tipos de asfaltos e temperaturas de ensaio para o agregado granito 107

Figura 4.14: Variação do módulo de resiliência em função do teor de asfalto para os diferentes tipos de asfaltos e temperaturas de ensaio para o agregado gabro.. 108

Figura 4.15: Variação do módulo de resiliência em função da temperatura de ensaio para os diferentes tipos e teores de asfalto para o agregado basalto 109

Figura 4.16: Variação do módulo de resiliência em função da temperatura de ensaio para os diferentes tipos e teores de asfalto para o agregado granito

Figura 4.17: Variação do módulo de resiliência em função da temperatura de ensaio para os diferentes tipos e teores de asfalto para o agregado gabro

Figura 4.18: Variação das relações entre os módulos de resiliência total (AASHTO) e as resistências à tração em função do tipo e teor de asfalto ou volume de vazios para o agregado basalto. 111

Figura 4.19: Variação das relações entre os módulos de resiliência total (AASHTO) e as resistências à tração em função do tipo e teor de asfalto ou volume de vazios para o agregado granito. 112

Figura 4.20: Variação das relações entre os módulos de resiliência total (AASHTO) e as resistências à tração em função do tipo e teor de asfalto ou volume de vazios para o agregado gabro

Figura 4.21: Relações entre os módulos de resiliência totais (esquerda) e instantâneos (direita) determinados segundo os procedimentos da AASHTO e do NCHRP, para todas as condições do experimento 114

Figura 4.22: Relações entre os módulos de resiliência totais e instantâneos determinados segundo os procedimentos da AASHTO (esquerda) e do NCHRP (direita), para todas as condições do experimento

Figura 4.23: Efeitos principais dos fatores nos valores médios das resistências à tração .... 117

Figura 4.24: Efeitos das interações entre os fatores na resistência à tração a $25^{\circ} \mathrm{C}$ 117 
Figura 4.25: Efeitos principais dos fatores nos valores médios dos módulos de resiliência totais (AASHTO) a $25^{\circ} \mathrm{C}$.

Figura 4.26: Efeitos das interações entre as variáveis no módulo de resiliência total (AASHTO) a $25^{\circ} \mathrm{C}$ 120

Figura 4.27: Efeitos principais das variáveis nos valores médios das relações MR total / RT a $25{ }^{\circ} \mathrm{C}$

Figura 4.28: Efeitos das interações entre as variáveis nas relações MR total / RT a $25^{\circ} \mathrm{C} . .122$

Figura 4.29: Efeitos principais dos fatores nos valores médios dos módulos de resiliência totais (AASHTO). 123

Figura 4.30: Efeitos das interações entre as variáveis no módulo de resiliência total (AASHTO) 124

Figura 4.31: Efeitos principais dos fatores nos valores médios da Recuperação Retardada 127

Figura 4.32: Efeitos das interações entre as variáveis na Recuperação Retardada. 128

Figura 4.33: Efeitos principais dos fatores nos valores médios do Atraso 130

Figura 4.34: Efeitos das interações entre as variáveis no Atraso 

Tabela 2.1: Procedimentos para a determinação do MR para a ASTM e SHRP 31

Tabela 2.2: Alguns métodos empíricos de determinação do módulo de resiliência (BARKSDALE et al., 1997). 37

Tabela 2.3: Classificação em função da porcentagem de sílica (Richards et al., 1991)........44

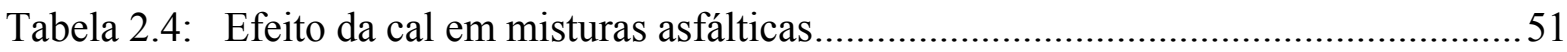

Tabela 2.1: Mecanismos de deterioração de pavimentos asfalticos (Richards et al., 1991) .67

Tabela 3.1: Distribuição granulométrica dos agregados do Programa I.............................. 73

Tabela 3.2: Caracterização do ligante asfáltico utilizado no Programa I ..............................73

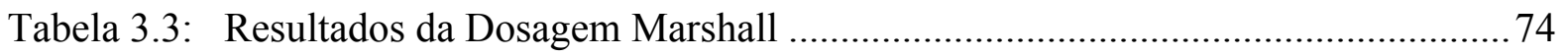

Tabela 3.4: Taxas de absorção de asfalto em função do método de moldagem..................... 74

Tabela 3.5: Composição granulométrica para enquadramento na faixa $\mathrm{C}$ do DNER ...........77

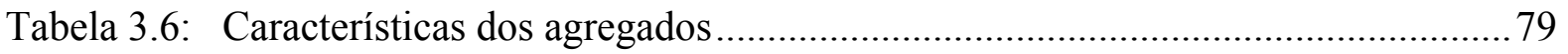

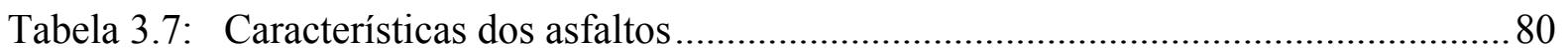

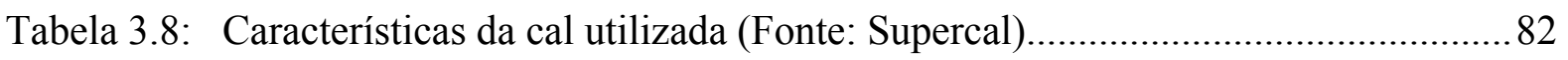

Tabela 3.9: Parâmetros Marshall das misturas asfálticas com CAP 20 ................................ 84

Tabela 3.10: Taxas de absorção de asfalto pelos agregados................................................... 86

Tabela 4.1: Valores médios de MR dos grupos ao longo do tempo .....................................94

Tabela 4.2: Significância dos fatores na variação do MR …….............................................. 98

Tabela 4.3: Volumes de vazios médios e desvios-padrões dos corpos-de-prova utilizados no Programa II

Tabela 4.4: Resistências à tração médias e desvios-padrões dos corpos-de-prova utilizados no Programa II

Tabela 4.5: Módulos de resiliência totais (AASHTO) médios dos corpos-de-prova utilizados no Programa II 105

Tabela 4.6: Valores médios e desvios-padrões das relações entre os módulos de resiliência totais (AASHTO) e as resistências à tração dos corpos-de-prova utilizados no Programa II 111

Tabela 4.7: Valores das variáveis do modelo para previsão da RT ..................................... 118

Tabela 4.8: Valores das variáveis para previsão da MR total em todas as temperaturas .... 125 



\section{LISTA DE ABREVIATURAS, SIGLAS E SÍMBOLOS}

AAAL Ao Ar e A Luz

AASHTO American Association of State and Highway of Transportation and Officials

AASL Ao Ar e Sem Luz

ABNT Associação Brasileira de Normas Técnicas

ANOVA Análise de Variância

ASTM American Society for Testing and Materials

At Atraso

AVAL Ao Vácuo e A Luz

AVSL Ao Vácuo e Sem Luz

CAP Cimento Asfáltico de Petróleo

CDM Condicionamento de misturas para projeto volumétrico

CENPES Centro de Pesquisas e Desenvolvimento da Petrobrás

COPPE Coordenação dos Programas de Pós-Graduação de Engenharia

CP Corpo-de-prova

DER-SP Departamento de Estradas de Rodagem do Estado de São Paulo

DMM Densidade Máxima Medida

DNC Departamento Nacional de Combustíveis

DNER Departamento Nacional de Estradas de Rodagem

DNIT Departamento Nacional de Infra-estrutura de Transportes

E Módulo de Elasticidade / Estabilidade

ECP Condicionamento de misturas para envelhecimento a curto prazo

F Fluência

HMA Hot Mixture Asphalt

IBP Instituto Brasileiro de Petróleo

IP Índice de Penetração

LTPP Long Term Pavement Program

LVDT Linear Variable Differential Transformer

MR Módulo de Resiliência

MR/RT Módulo de Resiliência / Resitência à Tração

$\mathrm{MR}_{\mathrm{I}} \quad$ Módulo de Resiliência Instantâneo

$\mathrm{MR}_{\mathrm{T}} \quad$ Módulo de Resiliência Total 


$\begin{array}{ll}\text { NBR } & \text { Norma Brasileira } \\ \text { NCHRP } & \text { National Cooperative Highway Research Program } \\ \text { NDoT } & \text { Nevada Departamento of Transportation } \\ \text { PVN } & \text { Número de Penetração - Viscosidade } \\ \text { RBV } & \text { Relação Betume Vazios } \\ \text { REDUC } & \text { Refinaria de Duque de Caxias } \\ \text { RR } & \text { Recuperação Retardada } \\ \text { SHRP } & \text { Strategic Highway Research Program } \\ \text { SMA } & \text { Stone Matrix Asphalt } \\ \text { SSD } & \text { Sutured Surface Dry } \\ \text { VIS } & \text { Viscosidade } \\ \text { VTS } & \text { Susceptibilidade Térmica - Viscosidade } \\ \text { Vv } & \text { Volume de vazios } \\ \varepsilon_{t} & \text { Deformação Específica Recuperável } \\ \mu & \text { Coeficiente de Poisson } \\ \sigma_{t} & \text { Tensão de Tração }\end{array}$


2.1 CONSIDERAÇÕES INICIAIS $\quad 27$

2.2 MÓDULO DE RESILIÊNCIA 28

2.2.1 Determinação do módulo de resiliência de misturas asfálticas 28

$\begin{array}{ll}2.2 .1 .1 \text { Com relação ao equipamento } & 31\end{array}$

2.2.1.2 Com relação à carga 32

2.2.1.3 Com relação à temperatura de ensaio e ao coeficiente de Poisson 33

2.2.1.4 Com relação ao condicionamento $\quad 34$

2.2.2 Correlações empíricas $\quad 35$

$\begin{array}{ll}\text { 2.2.3 Cálculo do módulo de resiliência } & 37\end{array}$

2.3 FATORES INFLUENTES NO COMPORTAMENTO DE MISTURAS ASFÁLTICAS 40

$\begin{array}{ll}2.3 .1 \text { Propriedades dos agregados } & 40\end{array}$

$\begin{array}{ll}2.3 .1 .1 \text { Fíleres } & 48\end{array}$

2.3.2 Propriedades dos asfaltos $\quad 52$

2.3.2.1 Suscetibilidade térmica de asfaltos e misturas asfálticas $\quad 55$

2.3.2.1 Índice de penetração (IP) $\quad 56$

2.3.2.2 Número Penetração-Viscosidade (PVN) 57

2.3.2.3 Suscetibilidade Térmica - Viscosidade (VTS) 57

2.3.2.5 Envelhecimento do asfalto e de misturas asfálticas $\quad 59$

$\begin{array}{ll}2.4 \text { CONSIDERAÇÕES FINAIS } & 67\end{array}$

CAPÍTULO 3 MATERIAIS E MÉTODOS

3.1 CONSIDERAÇÕES INICIAIS $\quad 69$

3.2 PROGRAMA I: AVALIAÇÃO DOS EFEITOS DAS CONDIÇÕES AMBIENTAIS NO ENRIJECIMENTO DE MISTURAS ASFÁLTICAS DENSAS 71

3.2.1 Características dos materiais $\quad 72$

3.2.3 Produção dos corpos-de-prova $\quad 74$

3.3 PROGRAMA II: AVALIAÇÃO DO EFEITO DE ALGUNS FATORES NA SUSCEPTIBILIDADE TÉRMICA DE MISTURAS ASFÁLTICAS DENSAS

3.3.1 Agregados $\quad 76$

3.3.1.1 Tipos e distribuição granulométrica $\quad 76$

$\begin{array}{ll}\text { 3.3.2 Características dos Agregados } & 78\end{array}$

$\begin{array}{ll}\text { 3.3.3 Asfaltos } & 79\end{array}$

$\begin{array}{ll}\text { 3.3.3.1 Tipos de asfalto } & 79\end{array}$

3.3.3.2 Temperaturas para preparação e compactação dos corpos-de-prova $\quad 80$

$\begin{array}{ll}3.3 .4 \mathrm{Cal} & 82\end{array}$

3.3.5 Misturas asfálticas $\quad 83$

3.3.5.1 Preparação das massas asfálticas $\quad 83$ 
3.3.5.2 Dosagens Marshall

3.3.5.3 Absorção de Asfalto pelo Agregado

3.4 ENSAIOS REALIZADOS

3.4.1 Módulo de resiliência

3.4.2 Resistência à tração

CAPÍTULO 4 APRESENTAÇÃO E DISCUSSÃO DOS RESULTADOS

4.2 PROGRAMA I: AVALIAÇÃO DOS EFEITOS DAS CONDIÇÕES AMBIENTAIS NO ENRIJECIMENTO DE MISTURAS ASFÁLTICAS DENSAS 93

4.3 PROGRAMA II: AVALIAÇÃO DO EFEITO DE ALGUNS FATORES NA SUSCEPTIBILIDADE TÉRMICA DE MISTURAS ASFÁLTICAS DENSAS 99

4.3.1 Considerações iniciais $\quad 99$

4.3.2 Características dos corpos-de-prova 100

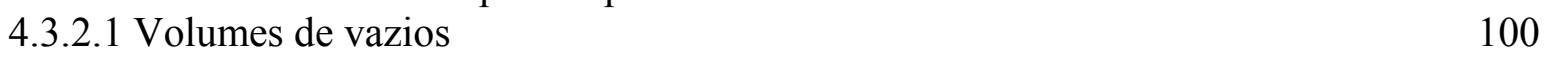

4.3.2.2 Resistências à tração 103

4.3.2.3 Módulos de resiliência $\quad 104$

4.3.2.4 Relações módulo de resiliência / resistência à tração - MR / RT 110

4.3.3 Resultados das análises estatísticas do experimento fatorial 115

4.3.3.1 Considerações iniciais $\quad 115$

4.3.3.2 Resistência à tração a $25^{\circ} \mathrm{C} \quad 116$

4.3.3.3 Módulo de resiliência total a $25^{\circ} \mathrm{C}$ (AASHTO) 119

4.3.3.4 Relação MR total / RT a $25^{\circ} \mathrm{C} \quad 121$

4.3.3.5 Módulo de resiliência total (AASHTO) 123

4.3.3.6 Recuperação Retardada $\quad 125$

$\begin{array}{ll}\text { 4.3.3.7 Atraso } & 128\end{array}$

4.4 CONSIDERAÇÕES FINAIS 131

CAPÍTULO 5 CONCLUSÕES

5.1 CONSIDERAÇÕES INICIAIS 133

5.2 CONCLUSÕES ACERCA DO PROGRAMA I: AVALIAÇÃO DOS EFEITOS DAS CONDIÇÕES AMBIENTAIS NO ENRIJECIMENTO DE MISTURAS ASFÁLTICAS DENSAS

5.3 CONCLUSÕES ACERCA DO PROGRAMA II: AVALIAÇÃO DO EFEITO DE ALGUNS FATORES NA SUSCEPTIBILIDADE TÉRMICA DE MISTURAS ASFÁLTICAS DENSAS

APÊNDICE I: DOSAGENS MARSHALL DOS AGREGADOS BASALTO, GABRO E GRANITO COM CAP 20 
APÊNDICE II: RESULTADOS DOS ENSAIOS DE MÓDULO DE RESILIÊNCIA NAS TEMPERATURAS DE $10,25 \mathrm{E} 40^{\circ} \mathrm{C}$

APÊNDICE III: RESULTADOS DOS ENSAIOS DE MÓDULO DE RESILIÊNCIA E RESISTÊNCIA À TRAÇÃO À $25^{\circ} \mathrm{C} \quad 160$

ANEXO A: ALGORITMO DAS REGRESSÕES PARA O CÁLCULO DO DESLOCAMENTO RESILIENTE INSTANTÂNEO 



\section{CAPÍTULO 1 INTRODUÇÃO}

Durante o desenvolvimento das atividades de avaliação e dimensionamento de pavimentos novos, ou mesmo quando do projeto de reabilitação de pavimentos existentes, surge a necessidade de conhecimento de um grande número de fatores que têm influência significativa nas decisões a serem tomadas, tais como as propriedades dos materiais, o tipo e o volume do tráfego a que o pavimento estará submetido durante o período de projeto, as condições ambientais, as técnicas construtivas e os materiais regionais disponíveis, etc. Dentre esses fatores, as propriedades dos materiais estão entre os mais importantes, principalmente no que tange ao projeto estrutural e ao futuro desempenho do pavimento quando em serviço.

Os procedimentos mais antigos para dimensionamento de pavimentos flexíveis têm como base correlações empíricas entre as propriedades mecânicas dos materiais e os seus desempenhos em campo quando empregados a pavimentos sob certas condições de solicitação. Com o surgimento dos métodos de dimensionamento de pavimentos baseados ou que se utilizam de conceitos mecanísticos, como o apresentado no guia da AASHTO de 1986, passou-se a considerar os módulos de resiliência dos componentes das camadas no procedimento de dimensionamento do pavimento.

Os métodos mecanísticos de dimensionamento de pavimentos fazem uso da teoria das camadas elásticas para simular os carregamentos a que eles estarão submetidos e avaliar o 
comportamento dos pavimentos em termos de tensões, deslocamentos e deformações. Assim, conhecer as relações tensão-deformação dos materiais constituintes do pavimento é fundamental para o seu dimensionamento, o qual é realizado como auxílio de programas computacionais que fazem uso da teoria das camadas elásticas.

Entretanto, as propriedades ou as relações tensão-deformação dos materiais que compõem as camadas dos pavimentos são dependentes dos materiais utilizados, ou seja, no caso de misturas asfálticas, por exemplo, podem exercer influência o tipo e teor de asfalto, o tipo e a distribuição granulométrica do agregado, o grau de compactação, etc. Além disso, essas propriedades ainda podem, em muitos casos, se alterarem em função de condições às quais esses materiais estejam submetidos, tais como temperatura, exposição à luz, umidade, etc.

Há, portanto, interesse em se estudar os fatores que exercem ou podem exercer influência significativa no comportamento dos materiais que compõem as camadas de pavimentos. Assim, o objetivo desta dissertação foi estudar a influência de alguns fatores, intrínsecos e extrínsecos, no comportamento de misturas asfálticas densas quanto à resiliência. Para tanto, foram estudados os efeitos, em misturas asfálticas, da utilização de diferentes tipos de agregados (três, dois de mesma composição mineralógica e outro distinto) e de asfaltos (dois, de consistências diferentes) na suscetibilidade térmica e da exposição à luz e ao ar no seu enrijecimento ao longo do tempo.

Para alcançar esse objetivo foram elaborados e executados dois experimentos. O primeiro objetivou avaliar suscetibilidade de misturas asfálticas densas compactadas ao envelhecimento em exposição ao ar e à luz. O segundo teve a finalidade de avaliar as influências da temperatura, dos tipos de agregado e do tipo e teor de asfalto nas propriedades 
resilientes de misturas asfálticas densas. Em ambos os programas a propriedade acompanhada foi o módulo de resiliência.

Além desse capítulo, que apresenta o trabalho, compõem essa dissertação mais quatro capítulos. O Capítulo 2 apresenta uma revisão bibliográfica acerca dos fatores que exercem influência na resiliência de misturas asfálticas densas. No Capítulo 3 são apresentados os o planejamento dos experimentos, os materiais, e os métodos utilizados durante a fase experimental. No Capítulo 4 são apresentados e discutidos os resultados obtidos das pesquisas, incluindo modelos de previsão de propriedades obtidos durante o desenvolvimento deste trabalho. Finalmente, no Capítulo 5, são apresentadas as principais conclusões obtidas dos resultados das pesquisas. 


\section{CAPÍTULO 2 REVISÃo BIBLIOGRÁFICA}

\subsection{CONSIDERAÇÕES INICIAIS}

A solução dos problemas relacionados à deterioração dos pavimentos é uma preocupação recorrente para a pavimentação. Os mecanismos de deterioração influem no desempenho do pavimento e se desenvolvem devido a um grande número de fatores intrínsecos e extrínsecos. Dentre os fatores intrínsecos, a seleção de materiais merece ênfase especial, uma vez que é a partir dela que se visa obter misturas com características reológicas, desempenho e durabilidade adequadas. Quanto aos fatores extrínsecos, destaca-se a influência das condições ambientais, pois sendo as misturas asfálticas suscetíveis à temperatura e ao envelhecimento é imprescindível a compreensão da ação de agentes do clima nas mesmas.

Muitas pesquisas já tiveram por objetivo a avaliação da influência de alguns fatores na suscetibilidade térmica e no envelhecimento de asfaltos. Nesta pesquisa, isso é feito pelo monitoramento do módulo de resiliência de misturas asfálticas compostas por diferentes materiais, a fim de considerar o efeito das interações entre os seus componentes e as variações decorrentes dessas interações no comportamento da suscetibilidade térmica e/ou de envelhecimento das misturas. Por isso, este capítulo apresenta uma revisão da literatura técnica que contempla dois itens principais: o módulo de resiliência e os fatores influentes no comportamento das misturas asfálticas. 


\subsection{MÓDULO DE RESILIÊNCIA}

\subsubsection{Determinação do módulo de resiliência de misturas asfálticas}

O módulo de resiliência (MR) é definido como a relação entre a tensão de tração aplicada repetidamente no plano diametral de uma amostra cilíndrica de mistura betuminosa e a deformação específica recuperável correspondente à tensão aplicada, numa dada temperatura (DNER ME 133), como mostra a expressão 2.1.

$$
M R=\frac{\sigma_{t}}{\varepsilon_{t}}
$$

Em que:

$\sigma_{\mathrm{t}}$ é tensão de tração $(\mathrm{MPa})$;

$\varepsilon_{\mathrm{t}}$ é deformação específica recuperável.

O comportamento de um material isotrópico e elástico linear pode ser caracterizado por duas constantes: o módulo de elasticidade ou de Young (E) e o coeficiente de Poisson ( $\mu)$. O módulo de resiliência é equivalente ao módulo de elasticidade porém é obtido através de solicitações de carregamentos repetidos de pequena intensidade (em relação à resistência do material), evitando que o material apresente deformações plásticas, assim sendo as deformações propiciadas pelos carregamentos são quase que completamente recuperadas. A partir de picos de deformação, devido ao carregamento e períodos de recuperação de um ensaio de módulo, são calculadas as constantes elásticas resilientes. 
Há atualmente um grande número de pesquisas que avaliam o módulo de resiliência de misturas asfálticas e, para isso, têm sido empregados ensaios variados, seguindo padronizações que se utilizam de métodos, técnicas e princípios diferentes, a saber: ensaios de tração por compressão diametral, de tração uniaxial, de compressão uniaxial, de compressão triaxial e de viga à flexão.

A experiência com os diversos tipos de ensaios levou a destacar algumas vantagens para determinados tipos de avaliações numa mistura asfáltica, por exemplo, o ensaio de tração indireta para estudos voltados à sua rigidez, ou o uso do ensaio de compressão triaxial para estudo dos efeitos da anisotropia do material (WALLACE e MONISMITH, 1980). Deste modo, valores diferentes dos módulos de resiliência podem ocorrer devidos não somente pela incidência de erros experimentais de origens diversas, mas também pelo próprio tipo de ensaio pelo qual se optou sua determinação.

Atualmente, o ensaio mais popular para a determinação do módulo de resiliência é o de tração por compressão diametral, sua vantagem deve-se à simplicidade da técnica e do equipamento e ao uso de corpos-de-prova Marshall.

O ensaio de módulo de resiliência por compressão diametral baseia-se no ensaio desenvolvido em 1943, pelo Professor Lobo Carneiro, para a determinação da resistência à tração do concreto. $\mathrm{O}$ conceito de deformabilidade de pavimentos foi desenvolvido por Francis Hveen por volta de 1955 e o primeiro registro do ensaio de módulo de resiliência em misturas asfálticas aconteceu na década de 70, com Schmidt da Chevron. 
No Brasil, o ensaio foi primeiramente adotado pela Coordenação dos Programas de PósGraduação de Engenharia (COPPE) para ensaios de módulo de resiliência e de fadiga (MEDINA, 2003) e atualmente encontra-se bastante difundido nas universidades e centros de pesquisa brasileiros, contudo ainda não é uma realidade para a indústria da pavimentação.

No ano de 1989, em uma reunião na Universidade do Estado de Oregon, discutiram-se as vantagens e desvantagens dos métodos de ensaio de módulo de resiliência, dentre eles, o da American Society of Testing and Material (ASTM), o da American Association of State Highway and Transportation Officials (AASHTO) e o do Strategic Higway Research Program (SHRP), que integra o "Long Term Pavement Performance Monitoring (LTPP) Program.

No Brasil, o procedimento laboratorial do ensaio para a determinação do módulo de resiliência é preconizado pelo Departamento Nacional de Estradas de Rodagem, no método de ensaio DNER ME 133, que em muito se assemelha à norma da AASHTO TP-31. Para destacar as características e as particularidades dos diferentes procedimentos de ensaios, na Tabela 2.1 são apresentados os métodos da ASTM, do DNER, da AASHTO, do SHRP e do NCHRP. 
Tabela 2.1: Procedimentos para a determinação do MR para a ASTM e SHRP

\begin{tabular}{|c|c|c|c|c|c|}
\hline Item & $\begin{array}{l}\text { ASTM } \\
\text { D } 4123\end{array}$ & $\begin{array}{c}\text { DNER } \\
\text { ME } 133\end{array}$ & $\begin{array}{c}\text { AASHTO } \\
\text { TP-31 }\end{array}$ & $\begin{array}{c}\text { SHRP } \\
\text { P-07 }\end{array}$ & $\begin{array}{c}\text { NCHRP } \\
\text { (Projeto 1-28) }\end{array}$ \\
\hline Ano & 1982 & 1986 & 1994 & 1992 & 2004 \\
\hline Equipamento & $\begin{array}{c}\text { Sistema } \\
\text { hidráulico ou } \\
\text { pneumático }\end{array}$ & $\begin{array}{c}\text { Sistema } \\
\text { especificação }\end{array}$ & $\begin{array}{l}\text { Sistema eletro- } \\
\text { hidráulico }\end{array}$ & $\begin{array}{l}\text { Sistema eletro- } \\
\text { hidráulico }\end{array}$ & $\begin{array}{l}\text { Sistema eletro- } \\
\text { hidráulico }\end{array}$ \\
\hline $\begin{array}{c}\text { Forma do pulso de } \\
\text { carga }\end{array}$ & $\begin{array}{c}\text { Senoidal ou } \\
\text { semi-seno-verso }\end{array}$ & $\begin{array}{c}\text { Sistema } \\
\text { especificação }\end{array}$ & $\begin{array}{l}\text { Semi-seno- } \\
\text { verso }\end{array}$ & $\begin{array}{l}\text { Semi-seno- } \\
\text { verso }\end{array}$ & $\begin{array}{l}\text { Semi-seno- } \\
\text { verso }\end{array}$ \\
\hline $\begin{array}{c}\text { Tempo de } \\
\text { aplicação de carga }\end{array}$ & $\begin{array}{c}\text { Duração de } 0,1 \\
\text { a } 0,4 \mathrm{~s} ; \\
\text { Freqüência } \\
0,33,0,5 \text { e } 1 \mathrm{~Hz}\end{array}$ & $\begin{array}{c}\text { Duração de } 0,1 \\
\text { s e freqüência } \\
\text { de } 1 \mathrm{~Hz}\end{array}$ & $\begin{array}{c}\text { Duração de } 0,1 \\
\text { s e freqüência } \\
\text { de } 1 \mathrm{~Hz}\end{array}$ & $\begin{array}{c}\text { Duração de } 0,1 \\
\text { s e freqüência } \\
\text { de } 1 \mathrm{~Hz}\end{array}$ & $\begin{array}{c}\text { Duração de } 0,1 \\
\text { s e freqüência } \\
\text { de } 1 \mathrm{~Hz}\end{array}$ \\
\hline Carga & $\begin{array}{c}10 \% \text { a } 50 \% \text { da } \\
\text { RT }\end{array}$ & $\begin{array}{c}\text { Menor que } 30 \% \\
\text { da RT }\end{array}$ & $\begin{array}{c}5^{\circ} \mathrm{C}-30 \% \mathrm{RT} \\
25^{\circ} \mathrm{C}-15 \% \mathrm{RT} \\
40^{\circ} \mathrm{C}-5 \% \mathrm{RT}\end{array}$ & $\begin{array}{c}5^{\circ} \mathrm{C}-30 \% \mathrm{RT} \\
25^{\circ} \mathrm{C}-15 \% \mathrm{RT} \\
40^{\circ} \mathrm{C}-5 \% \mathrm{RT}\end{array}$ & $15 \% \mathrm{RT}$ \\
\hline $\begin{array}{c}\text { Carga de } \\
\text { assentamento } \\
\text { (seating load) }\end{array}$ & $\begin{array}{c}\text { Sem } \\
\text { detalhamento }\end{array}$ & $\begin{array}{c}\text { Sem } \\
\text { detalhamento }\end{array}$ & $\begin{array}{c}\text { Sem } \\
\text { detalhamento }\end{array}$ & $\begin{array}{c}5^{\circ} \mathrm{C}-3,0 \% \mathrm{RT} \\
25^{\circ} \mathrm{C}-1,5 \% \mathrm{RT} \\
40^{\circ} \mathrm{C}-0,5 \% \mathrm{RT}\end{array}$ & $\begin{array}{c}\text { Sem } \\
\text { detalhamento }\end{array}$ \\
\hline $\begin{array}{l}\text { Medidas de } \\
\text { deformação }\end{array}$ & $\begin{array}{l}\text { LVDT em } \\
\text { suporte }\end{array}$ & $\begin{array}{l}\text { LVDT em } \\
\text { suporte }\end{array}$ & $\begin{array}{l}\text { LVDT em } \\
\text { suporte }\end{array}$ & $\begin{array}{l}\text { LVDT colado à } \\
\text { face do c.p. }\end{array}$ & $\begin{array}{l}\text { LVDT colado à } \\
\text { face do c.p. }\end{array}$ \\
\hline $\begin{array}{c}\text { Sugestão de } \\
\text { temperatura do } \\
\text { ensaio }\end{array}$ & $\begin{array}{l}5^{\circ} \mathrm{C} \\
25^{\circ} \mathrm{C} \\
40^{\circ} \mathrm{C}\end{array}$ & $30^{\circ} \mathrm{C}$ & $\begin{array}{l}5^{\circ} \mathrm{C} \\
25^{\circ} \mathrm{C} \\
40^{\circ} \mathrm{C}\end{array}$ & $\begin{array}{l}5^{\circ} \mathrm{C} \\
25^{\circ} \mathrm{C} \\
40^{\circ} \mathrm{C}\end{array}$ & $25^{\circ} \mathrm{C}$ \\
\hline $\begin{array}{c}\text { Eixo de } \\
\text { carregamento }\end{array}$ & Dois eixos & $\begin{array}{c}\text { Sem } \\
\text { detalhamento }\end{array}$ & & Um eixo & Dois eixos \\
\hline $\begin{array}{c}\text { Pré- } \\
\text { condicionamento }\end{array}$ & 50 a 200 pulsos & 200 pulsos & & $\begin{array}{c}50-150\left(5^{\circ} \mathrm{C}\right) \\
50-100\left(25^{\circ} \mathrm{C}\right) \\
20-50\left(40^{\circ} \mathrm{C}\right)\end{array}$ & $\begin{array}{c}\text { Mínimo de } 100 \\
\text { pulsos }\end{array}$ \\
\hline
\end{tabular}

\subsubsection{Com relação ao equipamento}

Com relação ao equipamento, é importante destacar que a recomendação das normas mais modernas para a utilização de equipamento eletro-hidráulico contribui para o melhor 
desempenho do sistema de aplicação de carga, que consiste basicamente de um cilindro com um pistão acoplado que transmite sobre um aplicador o esforço necessário para o carregamento. Esse tipo de sistema de aplicação de carga, quando movido a ar, pode apresentar alguma deficiência de preenchimento de ar, resultando num pulso de carga com tempo de aplicação diferente que $0,1 \mathrm{~s}$. Num equipamento eletro-hidráulico servo-controlado tem-se completo domínio da forma, da amplitude e da duração do pulso de carregamento.

\subsubsection{Com relação à carga}

As cargas repetidas simulam o efeito das passagens dos veículos no pavimento. O tráfego provoca no pavimento pulsos de tensões, de magnitudes variadas, que são aplicados repetidamente em cada elemento subjacente que o compõe e até uma dada distância ao lado das trilhas de roda. Próximo da superfície, o pulso de tensão tem uma forma sinusoidal pronunciada. Ao longo da profundidade a forma ainda se mantém sinusoidal, entretanto tende a uma conformação aproximadamente triangular (BARKSDALE et al., 1997).

A Figura 2.1 mostra a configuração dos carregamentos utilizados em ensaios para a determinação de módulos de resiliência. Os dois tipos de configurações apresentados são diferentes e utilizados de formas distintas. Nos equipamentos munidos de sistemas pneumáticos por limitações de funcionamento, por vezes, a forma de carregamento alcançada é a cíclica (Figura 2.1.a); Já nos equipamentos munidos de sistemas eletro-hidráulicos, a forma de carregamento é mais precisa e acompanha a forma sinusoidal (Figura 2.1.b). Devido a essa variação na forma dos carregamentos nos ensaios, os valores de módulos de resiliência podem se apresentar díspares. 


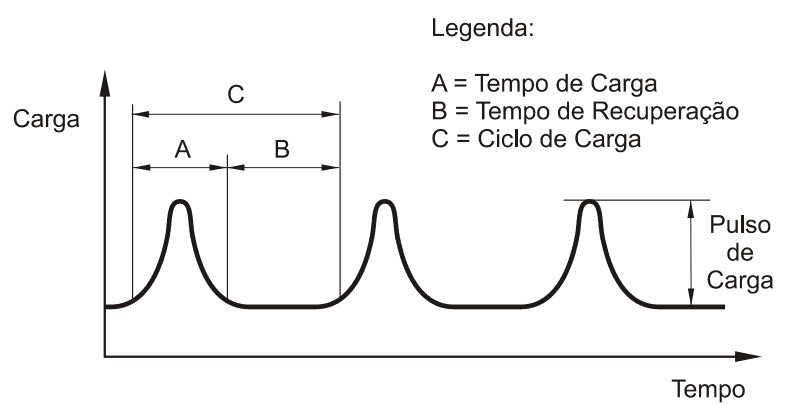

a) Carregamento cíclico

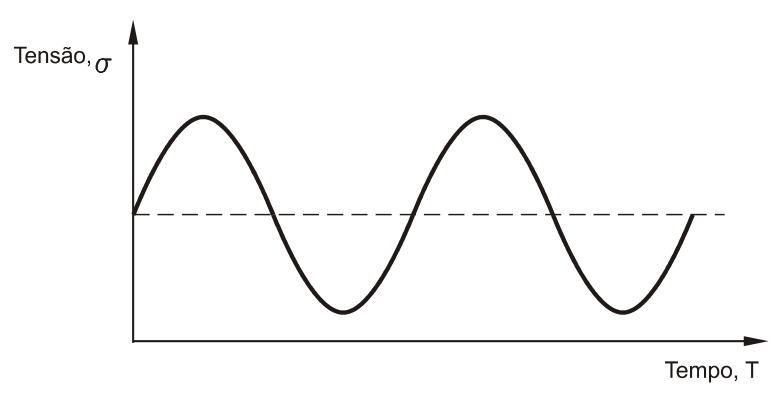

b) Carregamento sinusoidal

Figura 2.1: Configurações dos carregamentos utilizados em ensaio de MR

(BARKSDALE et al., 1997).

\subsubsection{Com relação à temperatura de ensaio e ao coeficiente de Poisson}

A temperatura de ensaio é um fator preponderante no módulo de resiliência. Algumas normas recomendam que o ensaio seja feito em uma única temperatura de ensaio, como as normas da NCHRP e do DNER. Entretanto, para estudos do efeito do comportamento de misturas asfálticas sob diferentes condições térmicas, algumas normas recomendam outras temperaturas, como acontece com as normas da ASTM, AASHTO e SHRP.

Considerando a variação da rigidez da mistura devido à temperatura, as normas sugerem que os ensaios sejam executados iniciando das menores para maiores temperaturas. Quanto ao coeficiente de Poisson, na falta de um sistema que possibilite sua medição, as normas sugerem o uso de valores diferentes em função da temperatura do ensaio, mas que, em geral, está compreendido no intervalo entre 0,1 e 0,5 .

No Brasil, para os cálculos de MR executados a $25^{\circ} \mathrm{C}$, é arbitrado o coeficiente 0,30 , enquanto que algumas normas estrangeiras consideram 0,35. Nesse sentido, Brito (2006) mostrou a sensibilidade do valor do MR para essa diferença $(0,05)$ e concluiu que essa variação provoca uma flutuação de cerca de 9\% na propriedade. Furlan (2006) também avaliou o impacto da 
adoção do valor de $\mu=0,35$ ao invés de 0,30 e reconheceu que a influência é constante e implicou numa majoração de $8,78 \%$ nos valores de todos MR calculados para a temperatura de $25^{\circ} \mathrm{C}$.

\subsubsection{Com relação ao condicionamento}

Alguns métodos possuem um condicionamento que é executado antes do ensaio propriamente dito, com a finalidade de que se estabilizem as deformações ou para a acomodação do corpode-prova no suporte para os casos em que não há recomendação de carga de assentamento.

Para o procedimento da SHRP, por exemplo, dependendo da temperatura do ensaio há um número de pulsos a ser adotado: para $5^{\circ} \mathrm{C}$ são de 50 a 150 pulsos, para $25^{\circ} \mathrm{C}$ de 50 a 100 pulsos e para $40^{\circ} \mathrm{C}$ de 20 a 50 pulsos. A norma recomenda que o pré-condicionamento seja interrompido, se ao proceder-lo, o corpo-de-prova apresente deformações maiores que $0,64 \mathrm{~mm}, 1,27 \mathrm{~mm}$ e $1,27 \mathrm{~mm}$ para $5^{\circ} \mathrm{C}, 25^{\circ} \mathrm{C}$ e $40^{\circ} \mathrm{C}$, respectivamente. $\mathrm{O}$ valor do $\mathrm{MR}$ do condicionamento deve ser relatado.

Para Furlan et al. (2006), reservar fases do ensaio para a acomodação inicial do corpo-deprova e a estabilização das leituras reduzem fontes de dispersões importantes ao longo do ensaio, pois nas primeiras aplicações de carga:

a) a parcela visco-elástica pode não ter sido "ativada";

b) pode haver alguma acomodação do corpo-de-prova e/ou;

c) pode conter alguma variação, de origem desconhecida, fora dos padrões dos desvios detectados. 
Na Figura 2.2 é apresentado um recorte de tela de ensaio de MR. Nela se pode observar a mudança inclinação da curva devida à acomodação do corpo-de-prova e as variações nas recuperações instantânea e total que se tornam mais discretas ao longo do ensaio, confirmando a necessidade de um período de condicionamento.
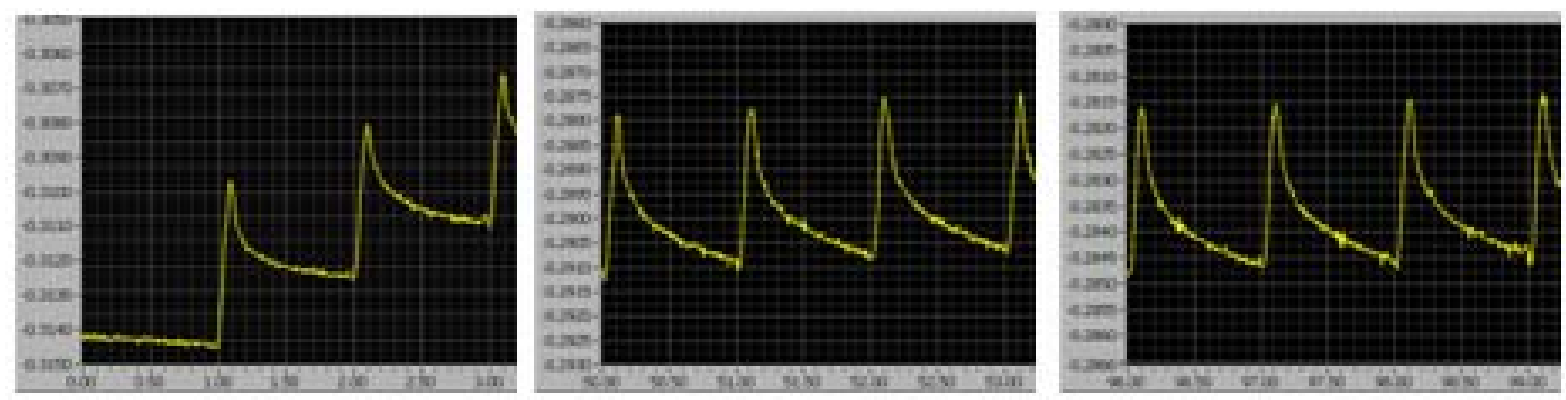

Da esquerda para a direita - 0 a 5 ciclos, 50 a 55 ciclos e 96 a 101 ciclos

Figura 2.2: Comportamento de uma mistura asfáltica nas primeiras solicitações de um ensaio de módulo de resiliência (FURLAN, 2006).

Comparando as diferentes normas, apresentadas na Tabela 2.1, nota-se que há uma preocupação maior no controle dos procedimentos pela SHRP, devido: (a) à exigência do controle de qualidade sistemático dos ensaios; (b) ao procedimento de alinhamento e assentamento do corpo-de-prova; (c) às novas equações de cálculo para módulo. Essas ações destinam-se ao controle e à redução do nível de variação ou de distorção que o valor do módulo pode vir a apresentar e à garantia da repetibilidade dos ensaios através da calibração temporária do equipamento, obtida a partir de ensaios em amostras sintéticas.

\subsubsection{Correlações empíricas}

O conhecimento acumulado sobre a resiliência das misturas asfálticas permitiram o desenvolvimento de métodos empíricos para a determinação do valor do módulo de resiliência. Apesar de esses métodos terem sido ajustados para fatores regionais e materiais de 
características particulares, pode-se dizer que os diversos pesquisadores que desenvolveram modelos buscaram aliar simplicidade (por meio de características obtidas de forma simples) e confiabilidade (considerando propriedades intervenientes no MR).

Na Tabela 2.2 encontra-se o resumo de algumas correlações para a determinação do módulo de resiliência de misturas asfálticas. Nota-se uma melhora dos modelos mais antigos para os atuais, na medida em que passaram a considerar um número maior de variáveis. Para Marques (2004), as principais variáveis influentes no MR podem ser resumidas nos seguintes grupos:
a) temperatura;
b) tempo e tipo de carregamento;
c) propriedades das misturas asfálticas;
d) tipo de ensaio;
e) tipo de corpo-de-prova.

Mesmo diante da praticidade das correlações, principalmente as menos complexas, que utilizam estabilidade, fluência e resistência à tração estática, os ensaios laboratoriais ainda são mais confiáveis para o diagnóstico da propriedade, mesmo que ainda existam problemas relacionados à repetibilidade e à reprodutibilidade. Por isso, atualmente as agências normativas e laboratórios têm focado os controles dos procedimentos laboratoriais, de calibrações e de cálculo do módulo com o intuito de reduzir as fontes de erros experimentais (equipamento, operação e cálculo). 
Tabela 2.2: Alguns métodos empíricos de determinação do módulo de resiliência (BARKSDALE et al., 1997).

\begin{tabular}{|c|c|}
\hline Pesquisadores & Propriedade relacionada \\
\hline Nijboer & Estabilidade/Fluência (Marshall) \\
\hline Mc Leod & Estabilidade/Fluência (Marshall) \\
\hline Van der Poel & $\begin{array}{l}\text { Tempo de carregamento, temperatura e penetração do } \\
\text { ligante }\end{array}$ \\
\hline Heukelom, Klomp e McLeod & $\begin{array}{c}\text { Módulo de rigidez do ligante e porcentagem de asfalto } \\
\text { e de agregados }\end{array}$ \\
\hline $\begin{array}{l}\text { Heukelon, Klomp e } \\
\text { Draat e Sommer }\end{array}$ & $\begin{array}{c}\text { Volume de asfalto, de agregados, e de vazios, módulo } \\
\text { de rigidez do ligante e concentração volumétrica de } \\
\text { agregados }\end{array}$ \\
\hline $\begin{array}{c}\text { Claessen } \\
\text { (Shell Design Manual) }\end{array}$ & $\begin{array}{l}\text { Módulo de rigidez do ligante, porcentagem de fração } \\
\text { fina de agregados e temperatura }\end{array}$ \\
\hline $\begin{array}{c}\text { Miller et al. } \\
\text { (Asphalt Institute Method) }\end{array}$ & $\begin{array}{l}\text { Temperatura, teor e viscosidade do ligante, volume de } \\
\text { vazios, porcentagem de finos, freqüência do } \\
\text { carregamento, viscosidade absoluta do ligante }\end{array}$ \\
\hline $\begin{array}{l}\text { DNER PRO } 269 \\
\text { (Motta e Pinto, 1994) }\end{array}$ & Resistência à tração estática \\
\hline Fonseca (1995) & $\begin{array}{c}\text { Porcentagens de frações de agregados, teor efetivo e } \\
\text { viscosidade de ligante, volume de vazios, freqüência do } \\
\text { carregamento }\end{array}$ \\
\hline Motta (1998) & $\begin{array}{l}\text { Penetração, ponto de amolecimento e porcentagem de } \\
\text { ligante, porcentagem de frações de agregados, volume } \\
\text { de vazios, RBV, temperatura do ensaio }\end{array}$ \\
\hline
\end{tabular}

\subsubsection{Cálculo do módulo de resiliência}

O módulo de resiliência é obtido a partir da carga, do deslocamento e das características do corpo-de-prova, como mostra a expressão 2.2. Dois valores de módulos podem ser obtidos: um em função do deslocamento resiliente total e outro do deslocamento instantâneo. A determinação pode ser feita por diferentes normas como: ASTM, AASHTO, SHRP e NCHRP. 
No país ainda não se encontra disponível uma norma que preconize o cálculo dos dois módulos, então para calcular $\mathrm{MR}_{\mathrm{T}}$ e $\mathrm{MR}_{\mathrm{I}}$ é necessário recorrer às normas estrangeiras. $\mathrm{O}$ cálculo dos módulos de resiliência determinados em ensaio de compressão diametral, tem como base a expressão 2.2. Atualmente, há uma tendência em utilizar o método de cálculo da NCHRP por ter levado a resultados mais repetíveis, o que foi conseguido a partir do uso de regressões hiperbólicas. Ressaltando essas inovações, serão discutidos dois métodos de cálculo, o AASHTO e o NCHRP.

$$
M R=\frac{F}{\Delta h}(0,9976 \mu+0,2692)
$$

Em que:

$M R$ é o módulo de resiliência em MPa;

F é a carga vertical repetida aplicada diametralmente ao corpo-de-prova, em N;

$\Delta$ é o deslocamento correspondente à deformação elástica ou resiliente sofrida pelo corpo-de-prova, em direção perpendicular à aplicação da carga), em mm;

h é a altura do corpo-de-prova, em mm;

$\mu$ é o coeficiente de Poisson.

$\mathrm{O}$ valor de $\mathrm{MR}_{\mathrm{T}}$ é obtido utilizando-se o deslocamento total recuperado durante o período de descarregamento e repouso. Segundo a AASHTO, é a diferença entre o deslocamento máximo do ciclo de carregamento e o deslocamento registrado no final do ciclo. Para a NCHRP, o deslocamento total é obtido pela diferença entre o deslocamento máximo do ciclo de carregamento e a média dos deslocamentos registrados no intervalo de 85 a $95 \%$ da porção de repouso do ciclo. 
Para o cálculo do $\mathrm{MR}_{\mathrm{I}}$ é utilizado o deslocamento instantâneo que, para a AASHTO, é a diferença entre o pico de deslocamento e um ponto obtido a partir do ajuste de duas regressões lineares: a) uma na porção de descarregamento, ajustada entre o ponto máximo de deslocamento e o ponto equivalente a $75 \%$ de retorno do deslocamento total; b) e outra na porção de repouso, ajustada entre o ponto de início e de fim do ciclo de repouso. No intercepto das duas regressões parte-se com uma reta vertical atingindo a curva onde se obtém o deslocamento resiliente instantâneo, como se pode observar no esquema da Figura 2.3.

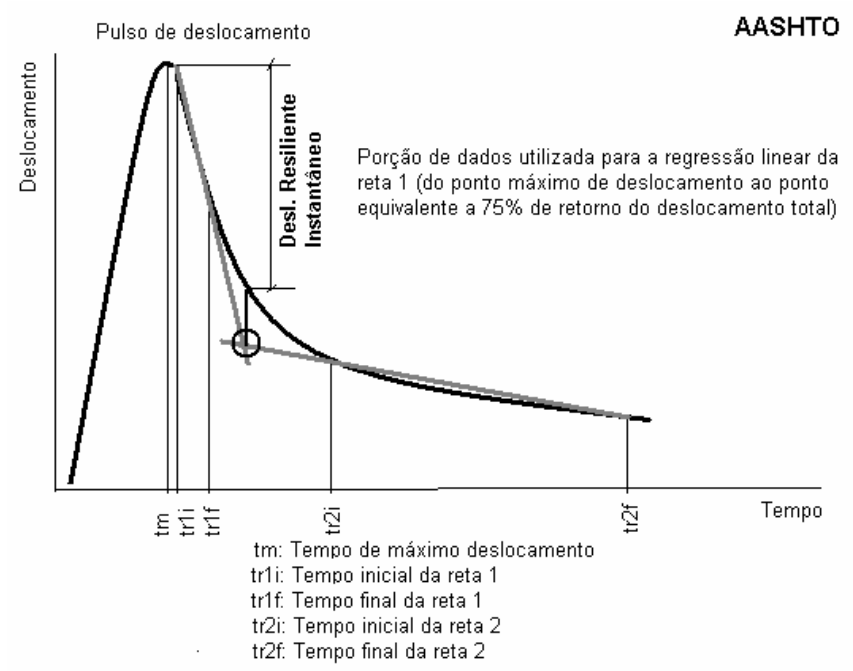

Figura 2.3: Deformações resilientes total e instantânea pela AASHTO (FURLAN, 2006).

$\mathrm{O}_{\mathrm{MR}}$ da NCHRP é calculado pela diferença entre o deslocamento máximo e um ponto na região da porção da curva que une a porção de descarregamento à porção de repouso. Para a determinação desse ponto é aconselhável o levantamento de alguns tempos de referência no pulso de deslocamento que delimitam o local de ajuste das regressões lineares e hiperbólicas, conforme Figura 2.4. O algoritmo das regressões para o cálculo do deslocamento instantâneo é apresentado no Anexo A (BRITO, 2006). A determinação do $\mathrm{MR}_{\mathrm{I}}$ pela NCHRP é mais 
complexo, devido à utilização das regressões hiperbólicas, em contrapartida esses artifícios minimizam as dispersões na determinação dos deslocamentos instantâneos.

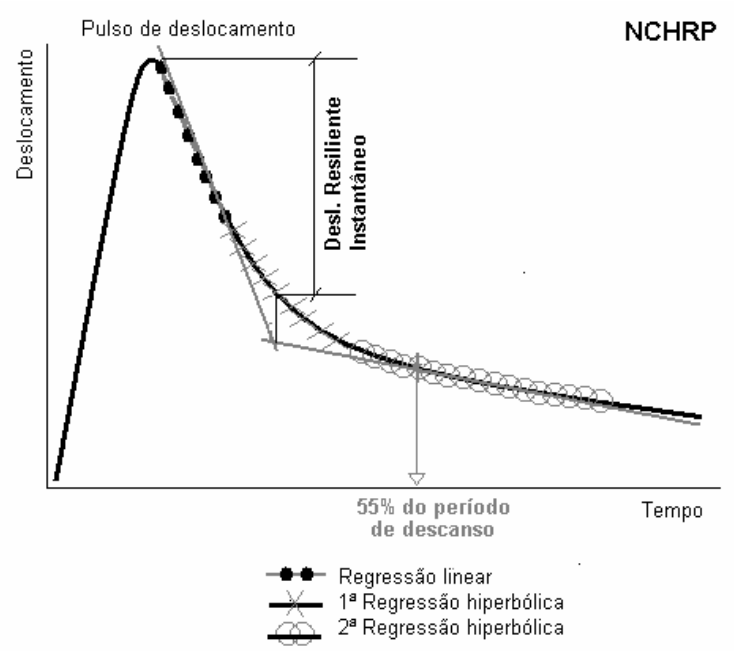

Figura 2.4: Curva de deformação para um ciclo de carregamento

(FURLAN, 2006).

\subsection{FATORES INFLUENTES NO COMPORTAMENTO DE MISTURAS}

\section{ASFÁLTICAS}

\subsubsection{Propriedades dos agregados}

Para a engenharia, os agregados são materiais granulares inertes que participam da composição de concretos, argamassas e alvenarias, cujas partículas são ligadas entre si por um aglutinante (em pavimentação o aglutinante é o Cimento Asfáltico de Petróleo, CAP). Os agregados imprimem respostas específicas no comportamento das misturas asfálticas, favorecendo seu embricamento, sua estabilidade, sua resistência à deformação permanente em trilhas de roda e sua vida de fadiga por meio de algumas propriedades físicas e químicas. 
Conforme o tamanho, os agregados podem ser classificados como graúdos e miúdos. Agregado graúdo é aquele que apresenta diâmetro máximo superior a 4,8 mm, por exemplo, a brita, a pedra-de-mão e o pedregulho natural; agregado miúdo é aquele com diâmetro máximo inferior a 4,8 mm, que compreende a areia, o pó-de-pedra e o pedrisco. As frações granulométricas são dosadas a fim de se obter misturas com características granulométricas adequadas e propriedades mecânicas e funcionais desejadas. Assim, numa dosagem de mistura asfáltica, o objetivo é obter uma combinação de agregados, asfalto e vazios que resulte em resistência, flexibilidade e durabilidade. Agregados bem graduados proporcionam misturas mais estáveis, quando comparadas às misturas com agregados não graduados e o aumento do tamanho máximo do agregado presente numa mistura aumenta sua rigidez. .

A faixa granulométrica é a distribuição das partículas, por tamanho, expressa em peso da mistura. Ela influencia diretamente nas diversas propriedades das misturas asfálticas (mecânicas, hidráulicas e de durabilidade); e é considerada como fator preponderante, principalmente, nas propriedades mecânicas, isso porque os agregados, por meio do atrito interno, devem transmitir as cargas do tráfego para as camadas subjacentes (RICHARDS et al., 1991).

Atualmente, há um grande número de soluções para revestimentos asfálticos; essas soluções têm exigências bastante rigorosas quanto às características dos agregados (inclusive faixa granulométrica) e dos asfaltos. Cada faixa granulométrica apresenta particularidades em seu embricamento e resistências. Nas misturas asfálticas compostas por agregados com faixa granulométrica de distribuição contínua, a resistência é assegurada pela máxima densidade, que é o caso dos concretos asfálticos. Faixas granulométricas descontínuas preconizam um esqueleto de agregado graúdo intertravado pelo mastique, como as misturas SMA (Stone 
Matrix Asphalt). A título de ilustração, a Figura 2.5 mostra dois corpos-de-prova, sendo um de mistura contínua (à esquerda) e o outro de mistura descontínua do tipo SMA (à direita). A despeito das propriedades típicas inerentes ao tipo de faixa granulométrica é importante relevar sobre os efeitos de outras variáveis como o tipo e o teor de asfalto, por exemplo.

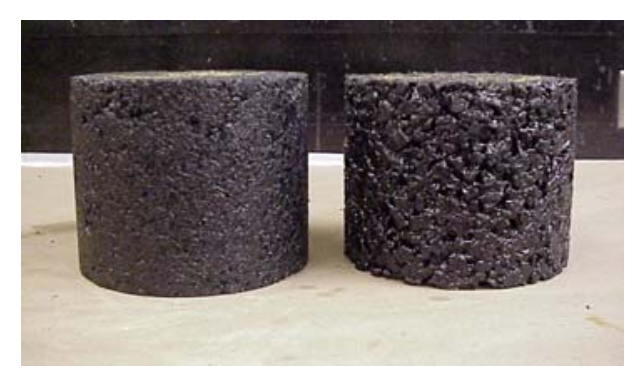

Figura 2.5: Exemplo de mistura contínua e descontínua

(Fonte: http://training.ce.washington.edu/)

Vale destacar que cada faixa granulométrica se aplica melhor em determinada função, nesse sentido a recomendação de seleção de misturas do NAPA (2001) é muito oportuna, porque de forma expedita pode-se encontrar uma indicação dos tipos de mistura asfáltica a se utilizar em função do tipo de tráfego, mas que, obviamente, não deve ser utilizada como ferramenta única.

Na introdução de misturas SMA nos Estados Unidos, Janoo e Korhonen (1999) observaram que a forma, a textura, a dimensão, a resistência da partícula e a estrutura do poro são outras características importantes no controle da deformação permanente, pois essas características dos agregados influem diretamente na qualidade do intertravamento do esqueleto mineral.

Para Furlan (2006), a composição dos minerais e dos cristais e a dureza intrínseca de alguns agregados promovem a formação de planos de ruptura característicos no processo de britagem, definindo a forma, a angularidade e as cargas elétricas superficiais do agregado 
produzido. A partir da composição mineralógica e da geologia dos agregados também pode se inferir:

a) sua dureza e sua resistência ao polimento, já que minerais com essas características são a priori materiais adequados ao uso em pavimentação;

b) sua forma e angularidade, uma vez que sua dureza determina a forma final do agregado britado e sua suscetibilidade ao desgaste/polimento;

c) sua estrutura cristalina, pois determinam a formação de cristais de tamanhos diferentes, podendo ser estruturas cristalinas compactas, densas e de granulação fina ou o inverso (LETTIER ${ }^{1}$ et al., 1949 apud GOUVEIA, 2006);

d) sua capacidade de absorção, uma vez que a dimensão do poro onde a água ou asfalto penetram depende da granulação dos cristais (LETTIER et al., 1949 apud GOUVEIA, 2006);

e) sua polaridade, visto que a britagem dos agregados forma planos de ruptura com cargas elétricas superficiais que podem ser balanceadas na ligação com o asfalto, por exemplo (YOON e TARRER, 1988);

f) sua afinidade com o asfalto, já que o aumento do teor de sílica aumenta sua afinidade com a água e as misturas compostas por eles apresentam problemas de adesão do agregado-asfalto e são propensas ao dano por umidade (MAJIDZADEH e BROVOLD, 1968);

g) a presença de pó na sua superfície, pois alguns tipos de agregados tendem a formar mais pó na britagem podendo se alojar na superfície do agregado.

${ }^{1}$ LETTIER, J. A.; FINK, D. F.; WILSON, N. B.; FARLEY, F. F. (1949). Mechanism of absorption of bituminous materials by aggregate. Association of Asphalt Pavement Technologists, v.18, p.278 - 300 . 
Devido à influência do agregado no desempenho das misturas asfálticas em serviço, a sua seleção é imprescindível. Como mencionado, a classificação dos agregados em função de seus constituintes minerais permite uma previsão do seu uso em pavimentação e podem ser classificados quanto ao seu teor de sílica $\left(\mathrm{SiO}_{2}\right)$ em três classes: ácidos, intermediários e básicos. A Tabela 2.3 mostra essa classificação e um resumo de suas particularidades.

Tabela 2.3: Classificação em função da porcentagem de sílica (RICHARDS et al., 1991).

\begin{tabular}{|c|c|c|c|}
\hline & Ácidas & Intermediárias & Básicas \\
\hline $\begin{array}{c}\text { Porcentagem de } \mathrm{SiO}_{2} \\
\text { Cor }\end{array}$ & maior que $66 \%$ & entre 55 e $66 \%$ & $\begin{array}{c}\text { menor que } 55 \% \\
\text { escura }\end{array}$ \\
\hline Presenca de quartzo livre & $\operatorname{sim}$ & & não \\
\hline Massa específico & menor que $2,75 \mathrm{~g} / \mathrm{cm}^{3}$ & & maior que $2,75 \mathrm{~g} / \mathrm{cm}^{3}$ \\
\hline
\end{tabular}

Outra classificação muito popular é a baseada na origem geológica do material, que classifica as rochas em ígneas, sedimentares e metamórficas. As rochas ígneas são cristalinas, formadas a partir do resfriamento do magma. As rochas sedimentares são formadas de resíduos insolúveis e rochas existentes desintegradas. As rochas metamórficas são rochas que podem ser formadas de rochas ígneas ou sedimentares cujas estruturas são alteradas por aquecimento e/ou alta pressão. De modo geral é bastante aceito que agregados ígneos sejam classificados como ácidos e não-ígneos como básicos. As rochas utilizadas nesta pesquisa são três: basalto, gabro e granito; segundo suas características (POPP, 1984), pode-se dizer que:

a) O basalto é uma rocha extrusiva básica muito comum em algumas regiões do Brasil. Os basaltos são formados predominantemente por feldspato, plagioclásio e piroxênio, e apresentam granulação de fina a muito fina (afanítica) e cores escuras que podem variar do vermelho escuro ao preto;

b) O gabro é uma rocha plutônica, básica frequentemente encontrada em intrusões médias a relativamente grandes, de incidência menor que o basalto. Os gabros são 
também formados predominantemente por feldspato, plagioclásio e piroxênio; e apresentam granulação média a grossa e cores muito escuras;

c) O granito é uma rocha intrusiva, ácida, encontrada em batólitos e outras massas muito grandes de rocha, de grande incidência em muitas regiões do Brasil. Os granitos são formados por quartzo e feldspato alcalino, e apresentam granulação média ou grossa e cores claras em tonalidades variadas de rosa e cinza.

A forma e angularidade do agregado permitem entender propriedades a resistência e a trabalhabilidade de uma mistura asfáltica. Por exemplo, agregados esféricos levam a intertravamentos pobres, pois tendem a se movimentar uns sobre os outros quando solicitados. Agregados lamelares podem ser suscetíveis à quebra e com isso tender a apresentar estratificação na mistura, aumento do consumo de asfalto (pelo aumento da área superficial), aumento do volume de vazios e diminuição da resistência da mistura.

Alguns pesquisadores acreditam que para uma mesma densidade, as misturas apresentariam estabilidade da mesma ordem, independente das características de forma, angularidade e textura dos agregados. Livneh e Greenstein (1972) recomendaram que a relação entre a dimensão máxima e mínima de agregados lamelares deveria ser menor que 3, a fim de que misturas asfálticas não apresentassem problemas de estabilidade.

Atualmente, é bem consolidado e aceito o conceito de que a melhor forma dos agregados a serem usados em pavimentação é a cúbica, pois resultam em maior atrito interno (menores vazios), maior resistência e em menores taxas de quebras agregados em operações de mistura, aplicação e compactação das misturas asfálticas. Gouveia (2006) avaliou a forma de agregados basálticos e gábricos e de uma areia natural (segundo a metodologia Superpave) e 
observou que o basalto apresentou $18 \%$ de partículas planas e alongadas, o gabro $6 \%$, e a areia natural $4 \%$.

Entretanto, a autora observou que as misturas asfálticas com agregados basálticos obtiveram porcentagens baixas de quebra de agregados, mesmo quando compactadas a diferentes energias (75, 110 e 155 golpes). Diante dessa inconsistência entre a previsão e a observação do comportamento, ela sugeriu que o limite máximo de partículas planas e alongadas fosse um quesito avaliado conjuntamente com outras propriedades como dureza e sanidade, propriedades estas que classificaram o agregado basáltico como resistente e durável, indicando materiais adequados para uso em pavimentação.

A dureza e a durabilidade são medidas obtidas dos ensaios de abrasão Los Angeles e do ensaio de sanidade. O ensaio de abrasão dá uma medida de resistência do agregado à degradação por abrasão e impacto, avaliada pela perda de massa de agregados. No ensaio de sanidade o agregado deve resistir à quebra e desintegração sob ação de ciclos de molhagem e secagem, e de congelamento e descongelamento, de uma solução salina concentrada. Esses ciclos parecem sem relação com as intempéries a que estão sujeitos os agregados e as misturas asfálticas em serviço, mas o ensaio de sanidade faz parte das avaliações necessárias à seleção de agregados.

Para a diferenciação entre os materiais, Richards et al. (1991) apresentaram valores típicos de abrasão, sendo para agregados basálticos, 10\%, e para os calcários, $60 \%$. Na seleção do agregado para misturas tipo concreto asfáltico (DNER ES 313), a abrasão Los Angeles deve ser menor ou igual a 40\%, admitindo material com abrasão maior se comprovado desempenho satisfatório em utilização anterior. Essa "tolerância" no limite preconizado parece concordar 
com Richards et al. (1991) que não acreditam numa relação consistente entre os resultados desse ensaio e do desempenho de agregados em misturas em serviço.

Para Richards et al. (1991), o melhor desempenho de uma mistura asfáltica é atribuído ao efeito combinado da forma cúbica e da textura rugosa dos agregados, devido à maior área superficial dos agregados rugosos, que favorece as ligações adesivas com o asfalto. Esses autores esclarecem que os agregados rugosos podem aumentar a resistência sobremaneira quando comparado aos lisos, mesmo exibindo a tendência de uma quantidade adicional de asfalto para superar uma trabalhabilidade supostamente menor.

Kim et al. (1992), avaliando a fadiga de misturas asfálticas compostas por agregados lisos e rugosos, observaram a fratura de agregados no plano de ruptura de corpos-de-prova de misturas com agregados rugosos enquanto que naquelas com agregados polidos houve descolamento do asfalto na interface agregado-asfalto. Além da redução do descolamento da película de asfalto do agregado, Bayomi (1992) listou outras vantagens do uso de agregados rugosos em misturas asfálticas como maior estabilidade e maiores resistência à deformação permanente e à fadiga.

É oportuno destacar que os agregados graúdos podem alojar finos em sua superfície, o que pode ser positivo quando há aumento da resistência da mistura. No entanto, os finos de uma mistura devem ser dosados objetivamente na seleção da graduação da mistura, observando condições de contorno e propriedades intrínsecas à faixa como resistência e permeabilidade, por exemplo. Em se tratando de agregados rugosos, a quantidade de finos está sujeita a aumentar para satisfazer propósitos de melhora no intertravamento do esqueleto mineral (SANDERS e DUKATZ, 1992). Outros tipos de contaminantes pulverulentos e ou líquidos na 
superfície dos agregados, como argilas e óleos são prejudiciais no desenvolvimento da adesão entre asfalto e agregado e comprometem a qualidade da massa e suas propriedades e seu desempenho (RICHARDS et al., 1991).

Um fator que vem ganhando destaque é a absorção de ligante pelo agregado. As principais propriedades dos agregados em relação ao processo da absorção são: a porosidade, a distribuição do tamanho dos poros e a composição mineralógica do agregado. Para Gouveia et al. (2004), o efeito da absorção de asfalto pelo agregado pode ser positivo quando em baixas taxas, pois melhora o intertravamento mecânico da mistura; por outro lado, quando absorção é alta, há diminuição da espessura da película de asfalto sobre o agregado, tornando a mistura mais suscetível às tensões e ao intemperismo.

A absorção do agregado também pode ser entendida em função da densidade, desta forma é diretamente relacionada com a porcentagem de poros na massa cristalina das partículas (LETTIER et al., 1949 apud GOUVEIA, 2004). De forma simplista, pode-se dizer que a porosidade de um agregado reflete a taxa de asfalto absorvida, sugerindo que quanto maior for a porosidade do material maior será a absorção de asfalto; entretanto, depende de outros fatores como tamanho dos canais e dos poros do agregado assim como da mobilidade do líquido absorvido, representada pela viscosidade do asfalto.

\subsubsection{Fíleres}

Atualmente, o fíler ${ }^{2}$ ou material de enchimento é objeto de estudo em muitas pesquisas devido à influência dessa fração nas propriedades do mastique, e conseqüentemente, no desempenho

\footnotetext{
${ }^{2}$ Material que possui no mínimo $65 \%$ de suas partículas com dimensão nominal inferior a $0,075 \mathrm{~mm}$.
} 
das misturas. Essa fração pode atuar de duas formas particulares (EPPS e LITTLE, 2001; SEBAALY et al., 2001; MOURA, 2001; MOURÃO, 2003):

a) como material inerte: promovendo o fechamento da mistura e aumentando sua estabilidade, normalmente pó-de-pedra;

b) como material ativo: alterando a trabalhabilidade da mistura, enrijecendo o mastique e contribuindo para o aumento das resistências ao envelhecimento e ao dano por umidade.

O uso da cal hidratada como fíler possui um efeito mais significativo, em comparação com outros fíleres como o cimento e o pó de pedra, esse efeito pode ser entendido em função da geometria das suas partículas, porque a cal hidratada tem em geral $80 \%$ de partículas de tamanho menor ou igual a $20 \mu \mathrm{m}$, enquanto que o cimento tem uma distribuição muito mais contínua, com diâmetro médio de aproximadamente $60 \mu \mathrm{m}$ e o pó de pedra possui graduação mais grossa com grande proporção de partículas maiores que $40 \mu \mathrm{m}$. Sendo assim, maiores quantidades de cal podem se concentrar no ligante disponível/efetivo e promover mudanças nas suas características originais.

Há muito tempo a cal tem sido utilizada em misturas asfálticas; historicamente a primeira mistura asfáltica com cal surgiu em 1910, em Boston e foi patenteada como Warrenite. Em 1920 outra mistura asfáltica com cal foi desenvolvida e chamada de Amiesita, com durabilidade superior em 50 anos quando comparada à Warrenite.

A partir de 1950, a maioria dos Departamentos de Transportes americanos recomendava a adição de cal em $1 \%$ a $2 \%$ em peso na mistura asfáltica. Contudo, ainda hoje os mecanismos 
pelos quais as cales atuam não são completamente descritos, alguns pesquisadores atribuem a melhora de algumas propriedades de engenharia observadas em misturas asfálticas ao aumento do $\mathrm{pH}$ proporcionado pela presença da cal (GUIMARÃES, 1985).

A maioria das pesquisas que estudam a presença da cal nas misturas asfálticas avaliam: (a) o efeito de sua interação na ligação da interface agregado-asfalto e na durabilidade e indiretamente (b) avaliam efeitos em outras propriedades mecânicas ou de durabilidade, ou seja, relacionadas à resistência, à flexibilidade e ao envelhecimento.

A cal é conhecida por seu papel como aditivo que melhora a adesão e a suscetibilidade de misturas asfálticas, e é normalmente aplicada em baixas taxas, de $1 \%$ a $2 \%$ em peso da mistura. A adição de cal pode ser feita de formas diferentes, como:

a) Cal seca no agregado úmido: o processo envolve a adição da cal durante a passagem do agregado na esteira;

b) Método da pasta: esse método consiste na preparação de uma pasta de cal e água aplicada na superfície dos agregados;

c) Injeção seca em misturas secas: consiste na adição de cal no cilindro de misturação ao mesmo tempo em que é adicionado o fíler.

A Tabela 2.4 apresenta um resumo de algumas conclusões obtidas por pesquisadores sobre os efeitos da cal em misturas com asfalto. 
Tabela 2.4: Efeito da cal em misturas asfálticas.

\begin{tabular}{|c|c|c|}
\hline Pesquisador & Objeto da pesquisa & Conclusão \\
\hline $\begin{array}{l}\text { Majidzadeh e Brovold } \\
\text { (1968) }\end{array}$ & $\begin{array}{l}\text { Estado-da-arte sobre adesão de } \\
\text { misturas asfálticas }\end{array}$ & $\begin{array}{l}\text { A cal reforça o mastique e atua como melhorador de } \\
\text { adesividade em misturas agregado-asfalto. }\end{array}$ \\
\hline $\begin{array}{l}\text { Hicks } \\
(1991)\end{array}$ & $\begin{array}{l}\text { Compilação em estado-da-arte } \\
\text { sobre dano por umidade de misturas } \\
\text { asfálticas }\end{array}$ & $\begin{array}{l}\text { A cal atua como melhorador de adesividade e pode } \\
\text { contribuir para melhora de propriedades mecânicas das } \\
\text { misturas asfálticas }\end{array}$ \\
\hline $\begin{array}{l}\text { Epps e Little } \\
(2001)\end{array}$ & $\begin{array}{l}\text { Estudo sobre efeito da cal em } \\
\text { misturas asfálticas }\end{array}$ & $\begin{array}{l}\text { A cal reduz o potencial do asfalto de se deformar em } \\
\text { altas temperaturas, porque atua enrijecendo e } \\
\text { reforçando o filme de asfalto dessa forma reduz a } \\
\text { suscetibilidade à deformação permanente. }\end{array}$ \\
\hline $\begin{array}{l}\text { Sebaaly et al. } \\
(2001)\end{array}$ & $\begin{array}{l}\text { Avaliação do desempenho da cal em } \\
\text { misturas asfálticas usinadas a } \\
\text { quente }\end{array}$ & $\begin{array}{l}\text { A adição de cal não teve impacto significativo nas } \\
\text { propriedades das misturas sob as ações combinada do } \\
\text { tráfego e meio ambiente, indicando que não houve } \\
\text { envelhecimento acelerado. }\end{array}$ \\
\hline $\begin{array}{l}\text { Moura } \\
(2001)\end{array}$ & $\begin{array}{l}\text { Estudo do efeito de aditivos } \\
\text { químicos e da cal como } \\
\text { melhoradores de adesividade de } \\
\text { misturas asfálticas densas }\end{array}$ & $\begin{array}{l}\text { A adição de } 1 \% \text { da cal hidratada melhorou } \\
\text { significativamente os resultados de módulo de } \\
\text { resiliência. }\end{array}$ \\
\hline $\begin{array}{l}\text { Cavalcanti e Soares } \\
\text { (2001) }\end{array}$ & $\begin{array}{l}\text { Avaliação do efeito da cal(em dois } \\
\text { teores } 2 \text { e 5\%) em misturas } \\
\text { asfálticas com teores de asfalto } \\
\text { iguais }\end{array}$ & $\begin{array}{l}\mathrm{O} \text { volume de vazios aumentou } 22 \% \text { com o aumento da } \\
\text { porcentagem de cal A resistência à tração também } \\
\text { aumentou em } 69 \% \text { com o aumento do teor de cal, } \\
\mathrm{O} \text { enrijecimento da mistura foi atribuído ao efeito de } \\
\text { fíler ativo da cal que aumenta a consistência do asfalto. }\end{array}$ \\
\hline $\begin{array}{l}\text { Leite \& Motta } \\
(2002)\end{array}$ & 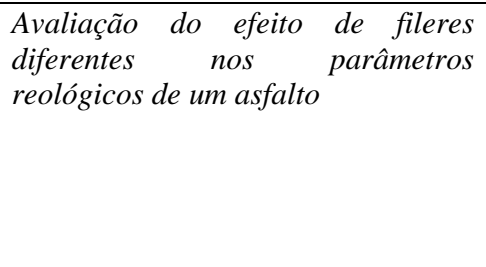 & $\begin{array}{l}\text { A adição fíler ao asfalto enrijece o mastique e este } \\
\text { fenômeno é muito mais intenso quando o fíler } \\
\text { incorporado é a cal hidratada, devido à sua maior } \\
\text { concentração nos mastiques e à sua maior área } \\
\text { superficial, como conseqüência a cal acarretou a menor } \\
\text { resistência à fadiga do ligante quando comparado a } \\
\text { outros fíleres (pó-de-pedra, cimento etc.). }\end{array}$ \\
\hline $\begin{array}{l}\text { Sebaaly et al. } \\
(2003)\end{array}$ & $\begin{array}{l}\text { Avaliação de técnicas de aditivos } \\
\text { anti-stripping em misturas asfálticas }\end{array}$ & $\begin{array}{l}\text { A cal fornece íons de cálcio substituindo } \mathrm{H}, \mathrm{Na}, \mathrm{K} \text { e } \\
\text { outros cátions da superfície do agregado e, em presença } \\
\text { de água, interage com os ácidos carboxílicos do asfalto } \\
\text { formando um produto insolúvel absorvido pela } \\
\text { superfície do agregado, eficiente na prevenção do } \\
\text { descolamento pela água, e reduz a taxa de oxidação. }\end{array}$ \\
\hline Wesseling et al. (2003) & $\begin{array}{l}\text { Avaliação de diferentes tipos de } \\
\text { fíleres em propriedades mecânicas e } \\
\text { de durabilidade de misturas } \\
\text { asfálticas }\end{array}$ & $\begin{array}{l}\text { A mistura com a cal teve um consumo menor de } \\
\text { asfalto, o que foi atribuído ao efeito de fíler ativo. A } \\
\text { estabilidade, a resistência à tração e o módulo de } \\
\text { resiliência apresentaram valores superiores, mostrando } \\
\text { o enrijecendo a mistura. }\end{array}$ \\
\hline $\begin{array}{l}\text { Mourão } \\
\text { (2003) }\end{array}$ & $\begin{array}{l}\text { Avaliação de misturas de alto } \\
\text { desempenho tipo SMA }\end{array}$ & $\begin{array}{l}\text { A adição de cal aumenta a viscosidade do meio coesivo } \\
\text { o que pode ser traduzido como maior resistência à } \\
\text { deformação. }\end{array}$ \\
\hline $\begin{array}{l}\text { Furlan } \\
(2006)\end{array}$ & $\begin{array}{l}\text { Avaliação de adesão e dano por } \\
\text { umidade de misturas asfálticas por } \\
\text { meio de ensaios mecânicos }\end{array}$ & $\begin{array}{l}\text { A presença da cal nas misturas asfálicas não imprimiu } \\
\text { mudanças significativas nas resistências à tração e nos } \\
\text { módulo de resiliência, mas atuou aumentando a } \\
\text { resistência ao dano por umidade. }\end{array}$ \\
\hline
\end{tabular}


O acompanhamento de revestimentos com agregados tratados com cal, nas regiões sul e nordeste do estado de Nevada, mostrou que a resistência ao efeito do congelamento e degelo (variação da umidade) aumentou quando comparadas às misturas sem a cal, além disso, sob as mesmas condições climáticas e de tráfego, as misturas com cal apresentaram melhor desempenho e menor necessidade de manutenção e reabilitação do pavimento durante sua vida útil, apresentando um aumento de três anos (em média) a mais de vida útil, o que representa cerca de $40 \%$ de acréscimo na expectativa de vida de serviço do pavimento (SEBAALY et al., 2003).

\subsubsection{Propriedades dos asfaltos}

De acordo com a American Society for Testing and Materials (ASTM) o asfalto é um material aglutinante castanho escuro ou preto, cujos constituintes principais são hidrocarbonetos de alto peso molecular, que ocorre na natureza ou é obtido através do processamento do petróleo. No Brasil, o derivado de petróleo usado como ligante dos agregados minerais, utilizados em misturas asfálticas para pavimentação, denomina-se cimento asfáltico de petróleo (CAP) e é um material de cor marrom a preta, termoplástico, com propriedades adesivas, impermeável à água, visco-elástico e pouco reativo.

Há uma grande dificuldade em definir a composição química dos asfaltos devido à sua grande variedade de substâncias, algumas ainda desconhecidas. Para o DNER o asfalto (CAP) é um sistema coloidal formado por micelas de asfalteno (parte sólida), constituídos de compostos polarizáveis capazes de se associar. Essas micelas de asfaltenos são peptizadas por resinas num meio intermicelar oleoso chamado de malteno (parte liquida). Os maltenos são 
constituídos de compostos não polares e são formados pela mistura de hidrocarbonetos aromáticos e saturados.

A quantidade, a forma e a natureza das micelas de asfaltenos e a proporção relativa dos hidrocarbonetos aromáticos e saturados comandam as propriedades reológicas e coloidais do asfalto. Se os asfaltenos e os maltenos apresentarem grande afinidade, a solvatação das micelas é grande e o sistema apresenta tendência à formação de micelas livres com película espessa entre elas, para essa situação, o asfalto apresenta grande susceptibilidade à temperatura, sendo chamado de CAP tipo SOL. Se a afinidade não é grande, a solvatação é deficiente, fazendo com que as micelas pouco solvatadas salientem sua assimetria, assim sendo favorecem a sua interligação e formam um esqueleto que fecham mecanicamente o óleo intermicelar, nesse caso, o asfalto é menos susceptível à ação da temperatura, sendo chamado de CAP tipo GEL (DNER, 1998).

Para os propósitos da engenharia, os asfaltos são considerados visco-elásticos e por isso apresentam os comportamentos elástico, viscoso ou visco-elástico, dependendo da temperatura e do tempo da aplicação de carga a que são submetidos. Então, em baixas temperaturas e tempos curtos de aplicação de cargas, o comportamento é aproximadamente elástico enquanto que, para altas temperaturas e tempos longos de aplicação de cargas, o comportamento apresenta-se ou, é mais próximo do viscoso (MONTEIRO, 1983 e LEITE et al.,1995). Então, com os asfaltos sendo classificados segundo sua consistência (tendo uma temperatura de ensaio como referência) pode-se indicar previamente um emprego em determinada condição de clima e de tráfego. 
Até a década de 70, asfaltos eram classificados segundo a sua penetração em quatro tipos: CAP 50-60, CAP 85-100, CAP 100-120 e CAP 150-200. Em 1992 o regulamento técnico 01/92 - REV. 02 do Instituto Brasileiro de Petróleo (IBP) e de acordo com a ABNT MB-827 passou a classificar os asfaltos pela sua viscosidade $\left(a 60^{\circ} \mathrm{C}\right)$ resultando em três classes CAP7, CAP-20 e CAP-40 e/ou pela penetração $\left(25^{\circ} \mathrm{C}\right)$, CAP 30-45, CAP 50-60, CAP 85-100 e CAP 150-200. Desde 2005, seguindo a resolução $n^{0} .19$, de 11 de julho de 2005 da Agência Nacional do Petróleo, Gás Natural e Biocombustíveis, os asfaltos voltaram a ser classificados pela sua penetração como: CAP 30-45, CAP 50-70, CAP 85-100 e CAP 150-200, conforme a ABNT NBR 6576.

Alguns autores acreditam que a classificação pela viscosidade seja mais vantajosa porque se trata de uma propriedade fundamental e por ser adequada para ambientes de vários tipos $\left(25^{\circ} \mathrm{C}\right.$ a $\left.60^{\circ} \mathrm{C}\right)$, ainda que se baseie na temperatura de $60^{\circ} \mathrm{C}$, que é muito próxima a temperatura do pavimento num dia de verão quente (RICHARDS et al., 1991). Além disso, não há faixas ausentes de classes de material, diferentemente do que ocorre na classificação pela penetração. Entretanto, há os que prefiram a classificação pela penetração por sua praticidade e pela vantagem de ser obtida a partir de um ensaio de princípio muito simples.

A consistência dos asfaltos tem sido observada em função de duas características principais: penetração e viscosidade, ou características relacionadas como o ponto de amolecimento.

O efeito do asfalto mais consistente em misturas asfálticas já é bastante conhecido. Misturas com esse tipo de asfalto normalmente apresentam maior rigidez, maior módulo de resiliência, maior resistência à deformação permanente e maior resistência à tração estática, quando comparadas a misturas de mesma faixa granulométrica e asfaltos menos consistentes (SOARES, 1995; MOTTA, 1993; MARQUES, 2004; FURLAN, 2006). 
A temperatura é um fator preponderante no desempenho de uma camada de revestimento. Os asfaltos como materiais termoplásticos apresentam consistências diferentes de acordo com a temperatura do meio. Essa característica do asfalto faz com que se apresente líquido a altas temperaturas permitindo que se misturem aos agregados, como ocorre na usinagem; em contrapartida, se submetidos a baixas temperaturas, o asfalto se apresenta no estado sólido. As misturas asfálticas, na temperatura de serviço, apresentam comportamento visco-elástico, que proporciona ao revestimento deformações resilientes como resposta às solicitações dinâmicas do trafego.

\subsubsection{Suscetibilidade térmica de asfaltos e misturas asfálticas}

A suscetibilidade térmica do ligante pode ser avaliada a partir de uma seqüência de ensaios em temperaturas diferentes, resultando num gráfico de temperatura versus rigidez. Quanto menor for a variação da rigidez apresentada pelo ligante em função da temperatura, menor é a sua suscetibilidade térmica.

Asfaltos altamente suscetíveis à temperatura são indesejáveis, pois exibem um intervalo mais estreito de controle da temperatura. Assim sendo, diante de pequenas variações de temperatura a consistência desses asfaltos é alterada significativamente, imprimindo nas misturas asfálticas características como:

a) tendência de trincamento (por retração ou por fadiga) devido à exposição a baixas temperaturas;

b) tendência à deformação permanente devido ao amolecimento quando expostas a temperaturas maiores que as de serviço; 
c) problemas de compactação devido às altas temperaturas que essa prática envolve.

Para Richards et al. (1991), a suscetibilidade térmica é uma taxa da mudança da consistência em função da mudança da temperatura. Em concordância com essa definição alguns estudos para a determinação da suscetibilidade do asfalto foram propostos enfocando características relacionadas à consistência sob diferentes temperaturas, como o índice de penetração, o número Penetração-Viscosidade e a Viscosity - Thermal Suscetibility (VTS) que são apresentados na seqüência.

\subsubsection{1 Índice de penetração (IP)}

Esse método considera a hipótese de que a penetração do asfalto no seu ponto de amolecimento é de 800, o que é discutível para asfaltos com resina e com ponto de amolecimento alto (RICHARDS et al., 1991). A relação entre penetração (PEN) e ponto de amolecimento (PA) e representada a seguir

$$
I P=\frac{20-500 A}{1+50 A}
$$

Em que:

$$
A=\frac{\log P E N_{1}-\log P E N_{2}}{T_{1}-T_{2}}
$$

Usualmente os valores de IP variam de -1 a 1 , sendo que quanto menor for o valor maior será a suscetibilidade térmica do asfalto. Um CAP que possui IP muito baixo, da ordem de -2 , por 
exemplo, significa que é altamente suscetível à temperatura apresentando fragilidade a baixas temperaturas.

\subsubsection{Número Penetração-Viscosidade (PVN)}

Esta relação foi proposta por McLeod baseada na penetração a $25^{\circ} \mathrm{C}$ e na viscosidade a $135^{\circ} \mathrm{C}$ ou $60^{\circ} \mathrm{C}$, que são normalmente obtidas por exigência da especificação para asfaltos e misturas asfálticas. Usualmente o valor de PVN varia de 0,5 a $-2,0$, e indica que quanto menor o valor de PVN maior será a suscetibilidade térmica do material. A expressão é apresentada a seguir:

$$
P V N=\frac{L-X}{L-M}
$$

Em que:

X é o logaritmo da viscosidade (cST) a $135^{\circ} \mathrm{C}$;

L é o logaritmo da viscosidade $(\mathrm{cST})$ a $135^{\circ} \mathrm{C}$ para $\mathrm{PVN}=0^{*}$;

M é o logaritmo da viscosidade $(\mathrm{cST})$ a $135^{\circ} \mathrm{C}$ para $\mathrm{PVN}=-1,5^{*}$;

(*Sendo L e M obtidos em um ábaco de penetração versus viscosidade)

\subsubsection{Suscetibilidade Térmica - Viscosidade (VTS)}

Essa relação de suscetibilidade térmica do asfalto é uma relação de viscosidade (VIS) em duas diferentes temperaturas $(T)$, como se observa na expressão a seguir:

$$
V T S=\frac{\log \log \left(V I S_{2}\right)-\log \log \left(V I S_{1}\right)}{\log T_{1}-\log T_{2}}
$$


O valor de VTS varia no intervalo estreito de 3,36 a 3,98, esses valores são diretamente proporcionais à suscetibilidade térmica do material, ou seja, quanto maior for VTS maior será a suscetibilidade térmica do asfalto.

Como se observa dessas relações, a suscetibilidade térmica da mistura asfáltica é obtida por inferência a partir da suscetibilidade térmica do asfalto, contudo vale lembrar que antes de qualquer extrapolação é recomendável considerar o sistema agregado-asfalto, pois suas respostas podem ser diferentes em função de interações variadas entre os diferentes materiais. Nesse sentido alguns estudos da suscetibilidade térmica de misturas asfálticas têm sido feitos com base na medida de propriedades das misturas asfálticas sob diferentes condições de temperaturas.

Taira et al. (2003), Marques (2004) e Gigante et al. (2006) apresentaram algumas contribuições ao estudo da suscetibilidade térmica de misturas asfálticas, observando a variação do módulo de resiliência de diferentes tipos de misturas asfálticas em diferentes temperaturas. Esses autores convergem ao considerar que a temperatura é o fator determinante na variação do valor de MR.

Taira et al. (2003), avaliando a suscetibilidade térmica de misturas asfálticas densas com ligantes convencionais e modificados em três teores, concluiu que a temperatura apresentou influência significativa nos valores de módulo de resiliência, assim como sua interação com o teor de ligante da mistura. Além disso, os autores observaram que a adição do polímero SBS diminuiu a susceptibilidade térmica das misturas asfálticas, principalmente em altas temperaturas, resultando numa menor redução relativa dos valores dos módulos de resiliência em função do aumento da temperatura. 
No desenvolvimento de um critério de dosagem de mistura asfáltica utilizando o módulo de resiliência, Marques (2004) concluiu que a temperatura foi o fator mais importante para a variação dos módulos e os outros fatores, por ordem de influência, foram a viscosidade, o teor de ligante e o tipo de compactação.

A avaliação da suscetibilidade térmica de misturas asfálticas de Gigante et al. (2006) considerou um programa experimental fatorial com os seguintes fatores: tipo de agregado, tipo e teor de ligante e temperatura. Seus resultados indicaram que as misturas com CAP 40 apresentaram menor sensibilidade às temperaturas de serviço que as com CAP 20 e que nas temperaturas baixas, as misturas apresentaram comportamentos similares, com ganhos de rigidez semelhantes e nas mesmas proporções para os módulos total e instantâneo.

\subsubsection{Envelhecimento do asfalto e de misturas asfálticas}

Apesar de apresentar uma inércia química do asfalto, os componentes orgânicos do asfalto em contato com o ar, a luz e a temperatura se alteram devido a diferentes processos. Para Richards et al. (1991), o envelhecimento do asfalto é explicado pela ocorrência de seis mecanismos:

a) Oxidação: Reação do oxigênio com o asfalto. A taxa de reação depende do asfalto e da temperatura;

b) Volatilização: Evaporação dos componentes leves do CAP dependente da temperatura do sistema. Usualmente não é significativa no envelhecimento em longo prazo;

c) Polimerização: Combinação de moléculas similares que produzem moléculas maiores, causando endurecimento progressivo; 
d) Tixotropia: Endurecimento devido à formação de estruturas no CAP, normalmente ocorre em revestimentos com baixa ou nenhuma solicitação;

e) Sinerese: Reação de exsudação em que os líquidos oleosos leves do CAP exsudam pela superfície do filme asfáltico, ficando a fração mais pesada;

f) Separação: Remoção de constituintes oleosos, resinas ou asfaltenos do CAP, é atribuída a absorção seletiva nos poros dos agregados.

Dos mecanismos mencionados, para Whiteoak ${ }^{3}$ apud Leite (1990) a mais importante causa do envelhecimento é a oxidação, que aumenta a viscosidade do asfalto pela introdução de oxigênio de natureza polar. A resposta do asfalto em termos de mudança de viscosidade depende também da sua origem e/ou composição. Segundo Petersen (1990), as mudanças nas propriedades físicas do asfalto, parecem ser comandadas pelo estado de dispersão dos seus componentes reativos, ou seja, dependem da capacidade apresentada pela fase solvente do asfalto de manter os componentes polares dispersos durante a oxidação, reduzindo seu efeito no aumento da viscosidade.

A mudança de consistência dos asfaltos é o que viabiliza as operações de mistura com o agregado, e é controlada através de uma faixa de viscosidade do asfalto. Os asfaltos como materiais termoplásticos apresentam consistências diferentes de acordo com a temperatura do meio. Essa característica do asfalto faz com que se apresente líquido a altas temperaturas permitindo que se misturem aos agregados, como ocorre na usina; e é nessa condição que se inicia o envelhecimento em curto prazo que se dá devido às altas temperaturas de mistura agregado-asfalto.

\footnotetext{
${ }^{3}$ WHITEOAK, D. SHELL Bitumen Handbook. Inglaterra, SHELL, 1990.
} 
Assim, no processo de envelhecimento em curto prazo o asfalto sofre mudanças de suas características reológicas como o aumento da viscosidade e a diminuição da penetração devido à perda de componentes voláteis, já no envelhecimento em longo prazo as mudanças reológicas no asfalto continuam, mas em uma taxa menor e mais lenta sendo mais perceptível entre os segundo e terceiro anos.

O estudo realizado por Petersen (1990) mostrou que no processo de envelhecimento em longo prazo, o aumento da viscosidade é lento, o que não acontece nas temperaturas elevadas dos testes acelerados de envelhecimento. No envelhecimento em longo prazo, conforme as moléculas mais reativas (moléculas de asfaltenos e polares aromáticas) se oxidam rapidamente se imobilizam em virtude da aglomeração decorrente da baixa energia térmica do sistema. Em conseqüência disso a capacidade das moléculas reagirem com o oxigênio, tornase altamente reduzida então o aumento da taxa de viscosidade e o tempo de envelhecimento diminui hiperbolicamente conforme aumenta o tempo de envelhecimento. Segundo Garrick (1995), essa situação corresponde ao envelhecimento ocorrido em temperaturas amenas.

Phromsorn e Kennedy (1995), avaliando diferentes procedimentos de simulação de envelhecimento em curto e em longo prazo, mostraram que ocorreu mudança na rigidez e na resistência à deformação permanente dos asfaltos o que atribuíram à volatilização e à oxidação, concomitantemente, houve aumento da fragilidade do asfalto e redução da resistência à fadiga e ao desgaste.

No que se refere à simulação do envelhecimento, os autores ressaltam que os procedimentos TFOT, RTFOT e PAV, podem não ser capaz de simular adequadamente o envelhecimento 
característico do asfalto em curto prazo e longo prazo por isso destacam que ainda há necessidade de se desenvolverem estudos e pesquisas que possam implementar procedimentos mais eficientes.

Alguns autores acreditam que a influência do tipo de asfalto é decisiva no efeito do seu enrijecimento causado por envelhecimento, de tal forma que os asfaltos mais viscosos podem ser mais resistentes ao processo de oxidação por apresentarem uma faixa de trabalho mais ampla, suportando temperaturas maiores que os asfaltos menos viscosos. Nesse sentido, Harvey e Tsai mostraram que o efeito do envelhecimento em longo prazo foi menor para misturas com asfaltos mais viscosos.

A absorção de ligante pelo agregado também acelera o envelhecimento da mistura, Kemp e Sherman (1984) estudaram a durabilidade de misturas asfálticas compostas por dois tipos de agregados, um com baixa absorção e outro com alta absorção e verificaram que a porosidade tem efeito significativo na taxa de oxidação sofrida pelo ligante asfáltico em regiões de clima quente.

Agregados mais porosos podem absorver os componentes oleosos do asfalto, acelerando o envelhecimento da película asfáltica que permanece na superfície. Para Bell (1989), quanto maior for a absorção de ligante e menos consistente for o asfalto, será mais significativo o envelhecimento.

Gouveia (2006) recomenda que se avalie a taxa de absorção de asfalto pelo agregado, uma vez que durante o processo de mistura, as características do tamanho do poro do agregado a menor consistência do ligante podem favorecer a absorção de asfalto ou de frações leves do 
asfalto, resultando em (a) teores de asfaltos diferentes dos de projeto ou (b) em asfaltos com composições químicas e propriedades reológicas, físicas e de envelhecimento diferentes das originais.

Visto que o envelhecimento é inevitável e, por conseguinte, o enrijecimento da mistura asfáltica; alguns procedimentos de envelhecimento vêm sendo propostos com intuito de simular e entender os mecanismos e as mudanças por ele proporcionadas. Esses procedimentos normalmente expõem misturas asfálticas a condições de temperatura e de pressão adversas, ora pelo emprego de altas temperaturas, ora pelo uso de ventilação forçada.

A AASHTO PP2 preconiza condicionamentos para simular os efeitos da dosagem e dos envelhecimentos em curto e em longo prazos, que são explicados a seguir:

a) Condicionamento de misturas para projeto volumétrico (CDM)

Aplica-se em misturas preparadas em laboratório antes da compactação (mistura solta). A mistura é colocada em recipiente numa espessura de 2,5 a 5,0 mm, onde permanece por duas horas em estufa de ventilação forçada por $2 \mathrm{~h} \pm 5 \mathrm{~min}$ na temperatura de compactação, sendo revolvida depois de $60 \pm 5$ min. para a manutenção das condições de uniformidade.

b) Condicionamento de misturas para envelhecimento em curto prazo (ECP)

Aplica-se em misturas preparadas em laboratório antes da compactação (mistura solta) com finalidade de simular efeitos do envelhecimento em curto prazo nas propriedades mecânicas das misturas asfálticas. A mistura é colocada em recipiente numa espessura de 2,5 a 5,0 mm, onde permanece por duas horas em estufa de ventilação forçada por 
$4 \mathrm{~h} \pm 5$ min na temperatura de $135^{\circ} \pm 3^{\circ} \mathrm{C}$, revolvendo a cada intervalo de $60 \pm 5 \mathrm{~min}$ para a manutenção das condições de uniformidade.

c) Condicionamento de misturas para envelhecimento em longo prazo (ELP)

Aplica-se em misturas preparadas em laboratório (após ECP) ou em amostras retiradas da rodovia com finalidade de simular efeitos do envelhecimento em longo prazo nas propriedades mecânicas das misturas asfálticas. Primeiramente, corpo-deprova/amostra é resfriado à temperatura ambiente, em seguida permanece por $16 \mathrm{~h} \pm 1 \mathrm{~h}$ em estufa a $60^{\circ} \mathrm{C}$.

A adoção de algum método de simulação de envelhecimento em geral resulta enrijecimento do asfalto e da mistura, Santana-Greco (2004), avaliando o efeito de diferentes métodos de envelhecimento em misturas asfálticas variadas, observou que todas apresentaram aumento do módulo de resiliência, diminuição da suscetibilidade à deformação permanente e a diminuição da recuperação elástica, o que pode ser traduzido como uma redução da resistência à fadiga. Essa autora ainda concluiu que as maiores variações de comportamento foram observadas em corpos-de-prova de misturas asfálticas deixadas sob ação do clima e atribuiu a esse comportamento particular de envelhecimento ao fator radiação ultra-violeta.

Verhasselt e Choquet (1993) estudaram a influência da luz natural em misturas asfálticas e constataram que cada componente da radiação causa um efeito específico e que a ultravioleta é mais danosa em termos de envelhecimento, atuando mais intensamente em películas finas de asfalto; já a radiação infravermelha aumenta a temperatura média do revestimento conforme é absorvida. 
Através da teoria da propagação da luz, Button (1996) demonstrou que a radiação ultravioleta quimicamente ativa atinge cerca de dois micrometros da película asfáltica; sua ação provoca a formação de compostos solúveis em água, tornando o efeito do intemperismo (chuva, sol, etc.) erosivo no topo da camada de revestimento asfáltico que está diretamente exposta à luz solar.

Gigante et al. (2005) sugerem a padronização de tempo máximo entre os processos de moldagem e testes de misturas asfálticas produzidas em laboratório. Esses pesquisadores monitoraram o módulo de resiliência de uma mistura asfáltica sob diferentes condições ambientais ao longo do tempo e mostraram que o enrijecimento da mistura asfáltica apresentou tendências de comportamentos particulares ao tipo de condição ambiental a qual estiveram sujeitas.

Dentre as principais constatações, Gigante et al. (2005) mostraram a condição ambiental natural promoveu aumento no módulo de resiliência mais contínuo e gradual, enquanto que misturas expostas às condições de luz e vácuo artificiais exibiram após um período de grande variação do módulo seguida de uma fase de desaceleração do enrijecimento; mostrando estatisticamente que o clima foi a condição ambiental significativa na variação do módulo de resiliência.

Said (2005) monitorou propriedades mecânicas de misturas asfálticas de pavimentos em serviço ao longo do período de 3 anos, e observou que:

a) as taxas de envelhecimento apresentaram diferentes intensidades para misturas com diferentes agregados e asfaltos,; 
b) o enrijecimento das misturas foi maior no primeiro ano;

c) o módulo de resiliência exibiu um aumento de $20 \%$ no período do estudo.

As principais conclusões do SHRP A-003A sobre os estudos de envelhecimento remetem à: influênciam do agregado e do asfalto, sendo que o envelhecimento de alguns tipos de asfalto pode ser solucionado por alguns agregados e menos por outros; essa variabilidade do grau de envelhecimento para quatro diferentes combinações de agregado asfalto foi relacionada à adesão desenvolvida entre agregado e asfalto.

Baseado na hipótese de que a adesão desempenha um papel importante na determinação das características de envelhecimento, poderia ser suposto que a combinação da cal com granitos reduziria a tendência de envelhecimento. Por outro lado, um asfalto classificado como pobre em termos de suscetibilidade ao envelhecimento não apresentou melhora dessa condição devido a nenhuma outra combinação seja com agregados calcários, seixos e/ou granitos (HARVEY e TSAI, 1997).

Em concordância com as conclusões do SHRP A-003A, Sonsnovske et al. (1993) mostraram que determinados pares agregado-asfalto apresentam menor suscetibilidade ao envelhecimento, e relacionaram-na com maiores resistências da ligação química (adesão) entre agregado-asfalto; para esses pesquisadores, quanto melhor for a ligação adesiva, menor será o envelhecimento.

Bell (1989) afirmou que o aumento do módulo de resiliência decorrente do envelhecimento da mistura asfáltica é uma tendência comportamental observada por muitos pesquisadores, no entanto, no que se refere a outras propriedades como vida de fadiga, por exemplo, essa 
constatação não é geral. Kim et al. (1987) verificaram que as misturas asfálticas sujeitas ao envelhecimento apresentaram aumento do módulo de resiliência sem, com isso, exibir aumento da vida de fadiga.

\subsection{CONSIDERAÇÕES FINAIS}

Como tanto a suscetibilidade térmica quanto o envelhecimento das misturas asfálticas podem alterar o desempenho das misturas asfálticas, para melhor observar o efeito desses fatores no desenvolvimento de defeitos em misturas asfálticas, a Tabela 2.3 mostra uma compilação dos principais mecanismos de deterioração de pavimentos asfálticos.

Tabela 2.3: Mecanismos de deterioração de pavimentos asfálticos (RICHARDS et al., 1991).

\begin{tabular}{|c|c|c|}
\hline Defeito & Causas & Comentários \\
\hline $\begin{array}{l}\text { Desgaste } \\
\text { Perda de agregados na superfície de } \\
\text { rolamento que evoluem para baixo } \\
\text { podendo chegar a delaminação }\end{array}$ & $\begin{array}{l}\text { Baixa porcentagem de finos } \\
\text { Baixo teor de asfalto } \\
\text { Compactação inadequada } \\
\text { Envelhecimento do asfalto }\end{array}$ & $\begin{array}{l}\text { A indução ao desgaste prematuro } \\
\text { pode se dar pelo enrijecimento da } \\
\text { mistura devido ao endurecimento do } \\
\text { asfalto. }\end{array}$ \\
\hline $\begin{array}{l}\text { Trincas } \\
\text { Perda de resistência que o material } \\
\text { sofre quando solicitado repetidamente, } \\
\text { caracteriza-se por trincas (que se } \\
\text { desenvolvem de baixo para cima) ou } \\
\text { fratura completa após um número } \\
\text { suficiente de repetições do } \\
\text { carregamento }\end{array}$ & $\begin{array}{l}\text { Escorregamento } \\
\text { Retração (associadas a não } \\
\text { solicitação) } \\
\text { Reflexão }\end{array}$ & $\begin{array}{l}\text { O revestimento asfáltico pode tornar- } \\
\text { se suscetível fadiga quando o ligante } \\
\text { apresenta-se enrijecido, assim sob } \\
\text { condições de baixas temperaturas e/ou } \\
\text { envelhecimento do ligante, as } \\
\text { misturas podem ser predispostas a } \\
\text { apresentarem trincamento por fadiga. }\end{array}$ \\
\hline $\begin{array}{l}\text { Deformação permanente } \\
\text { Depressões longitudinais que ocorrem } \\
\text { por densificação/ consolidação ou por } \\
\text { fluxo plástico, por vezes são } \\
\text { acompanhadas de elevações laterais } \\
\text { que ocorrem ao longo das trilhas-de- } \\
\text { roda. Sua formação é gradativa e em } \\
\text { função do aumento do número de } \\
\text { solicitações }\end{array}$ & $\begin{array}{l}\text { Compactação inadequada } \\
\text { Alto Vv } \\
\text { Alto teor de asfalto } \\
\text { Agregados arredondados, lisos ou } \\
\text { lamelares } \\
\text { Asfalto inadequado para } \\
\text { determinado ambiente } \\
\text { Baixo teor de fíler }\end{array}$ & $\begin{array}{l}\text { O revestimento asfáltico pode tornar- } \\
\text { se suscetível à deformação } \\
\text { permanente quando o ligante } \\
\text { apresenta-se menos viscoso, o que } \\
\text { pode ser ocorrer em ambientes com } \\
\text { climas quentes. Em contrapartida o } \\
\text { aumento da viscosidade do asfalto } \\
\text { pode aumentar a rigidez da mistura. }\end{array}$ \\
\hline $\begin{array}{l}\text { Stripping } \\
\text { Fragilidade ou perda da ligação } \\
\text { adesiva devida à presença de água no } \\
\text { sistema }\end{array}$ & $\begin{array}{l}\text { Particularidade dos materiais } \\
\text { Incompatibilidade do par } \\
\text { agregado-asfalto } \\
\text { Má execução da mistura } \\
\text { Compactação inadequada } \quad(\mathrm{Vv} \\
\text { alto) } \\
\text { Baixo teor de asfalto }\end{array}$ & $\begin{array}{l}\text { A película de asfalto pode ser mais } \\
\text { resistente à ação da água se o ligante } \\
\text { for mais consistente, de certa forma o } \\
\text { envelhecimento enrijece o asfalto (e a } \\
\text { mistura) contribuindo para aumentar } \\
\text { sua resistência à ação da água. }\end{array}$ \\
\hline
\end{tabular}


Como se pode observar, em casos de deformação permanente, fadiga e descolamento de película (stripping), a experiência mostra que o efeito da suscetibilidade térmica do ligante e do envelhecimento, desde que atuem enrijecendo a mistura asfáltica, podem ser positivos, pois previnem o desenvolvimento prematuro desses defeitos. No desgaste, contrariamente, o efeito desses fatores proporcionam um tipo de "ressecamento" na mistura asfáltica que, aliado às possíveis causas (por ex.: teor baixo de asfalto e/ou de finos), aceleram esse mecanismo. 


\section{CAPÍTULO 3 MATERIAIS E MÉTODOS}

\subsection{CONSIDERAÇÕES INICIAIS}

Para alcançar os objetivos propostos nesta pesquisa foi necessário dividi-la em duas partes. Assim, foram elaborados dois programas de pesquisa, denominados Programa I e Programa II. O primeiro teve como objetivo avaliar o efeito das condições ambientais (exposição ao ar e à luz) na flexibilidade de uma mistura asfáltica ao longo de um dado período de tempo; o segundo foi planejado para tentar compreender quais são as influências do tipo de agregado, da presença de cal e do tipo e do teor de asfalto na flexibilidade e na suscetibilidade térmica de misturas asfálticas.

Os dois programas experimentais foram desenvolvidos considerando a interação de alguns fatores previamente selecionados, que resultaram em 128 corpos-de-prova, sendo que 20 deles fizeram parte do primeiro programa, sobre o efeito das condições ambientais no enrijecimento, e 108 do segundo programa, sobre o efeito dos materiais na flexibilidade e na susceptibilidade térmica.

Ambos os programas utilizaram o módulo de resiliência como variável de resposta, por duas razões: primeiro por ser considerada a propriedade fundamental que reflete a flexibilidade das misturas asfálticas, e segundo por se tratar de um ensaio não destrutivo e, por isso, permitir 
avaliar variações da propriedade numa mesma amostra, evitando o aumento de erros experimentais.

Cabe ainda esclarecer que esta pesquisa foi desenvolvida em conjunto com outras duas, uma em nível de doutorado e outra em nível de mestrado. As três tiveram como objetivos principais avaliar adesividade de ligantes asfálticos a agregados pétreos (FURLAN, 2006), resistência à fadiga (IWANAGA, 2007) e suscetibilidade térmica de misturas asfálticas, objeto da presente dissertação. Com esses objetivos em comum, foi formado uma espécie de cooperativa de trabalho e os três pesquisadores envolvidos partilharam os mesmos materiais (agregados e asfaltos) e dividiram o trabalho de caracterização dos materiais, moldagem dos corpos-de-prova e execução de ensaios de laboratório. Assim, alguns dos resultados apresentados neste trabalho poderão ser encontrados em outros, já que os materiais e métodos utilizados foram os mesmos.

Neste capítulo são apresentadas as descrições e características dos materiais e dos métodos utilizados na pesquisa para produção e avaliação dos corpos-de-prova de misturas asfálticas, além de detalhes dos dois experimentos planejados. A apresentação é feita por programa de investigação, pois eles foram executados em épocas diferentes e não compartilham, em alguns casos, os mesmos materiais. 


\subsection{PROGRAMA I: AVALIAÇÃO DOS EFEITOS DAS CONDIÇÕES AMBIENTAIS NO ENRIJECIMENTO DE MISTURAS ASFÁLTICAS DENSAS}

Este programa experimental teve a finalidade de avaliar os efeitos que as condições ambientais exercem no valor do módulo de resiliência de misturas asfálticas densas ao longo do período de estocagem. Foram consideradas cinco condições ambientais distintas, a saber:

a) Ao ar e à luz (AAAL): Os corpos-de-prova foram colocados sobre a bancada de uma sala, sem qualquer tipo de proteção, onde ficaram expostos à luz artificial fluorescente ininterruptamente durante o período do experimento. A face exposta à luz foi alternada a cada dois dias;

b) Ao ar e sem luz (AASL): Os corpos-de-prova, sem qualquer tipo de proteção, foram armazenados numa caixa, para evitar a entrada de luz;

c) Sob baixa pressão atmosférica e à luz (AVAL): Os corpos-de-prova foram armazenados em um dessecador de vidro e mantidos a vácuo (obtido por meio de uma bomba de vácuo), onde ficaram expostos à luz artificial fluorescente ininterruptamente durante o período do experimento. Os corpos-de-prova foram apoiados diametralmente dentro do dessecador;

d) Sob baixa pressão atmosférica e sem luz (AVSL): Os corpos-de-prova foram armazenados em um dessecador e mantidos a vácuo, cobertos por um tecido escuro para evitar a entrada de luz. Os corpos-de-prova foram apoiados diametralmente dentro do dessecador;

e) Ao clima e às intempéries (CLIMA). Os corpos-de-prova permaneceram em uma superfície plana, e expostos ao clima e às intempéries (sol e chuva), sem qualquer tipo de proteção. A face exposta à luz foi alternada a cada dois dias. 
Foram produzidos 20 corpos-de-prova de mistura asfáltica composta de agregado basáltico e CAP 20, com 5,5\% de asfalto em peso, segundo o procedimento da AASHTO PP2. Após a moldagem, foram subdivididos em cinco grupos e cada grupo foi submetido a uma das condições ambientais particulares descritas anteriormente.

Antes dos ensaios de avaliação de propriedades mecânicas, os corpos-de-prova do grupo CLIMA foram transferidos para uma sala climatizada com temperatura controlada a $25 \pm 1^{\circ} \mathrm{C}$, onde permaneciam por, no mínimo $4 \mathrm{~h}$ antes do ensaio, a fim de homogeneizar a temperatura. Os corpos-de-prova dos outros grupos foram mantidos durante toda a duração do experimento em uma sala com temperatura controlada a $25 \pm 1^{\circ} \mathrm{C}$, durante todo o período do estudo.

Após a produção, os corpos-de-prova foram submetidos a ensaios para determinação do valor do módulo de resiliência inicial e, posteriormente, foram novamente ensaiados a cada sete dias, até completarem seis semanas desde a data de moldagem.

\subsubsection{Características dos materiais}

Foram utilizados agregados de origem basáltica, originários da Pedreira Bandeirantes Ltda., que foram peneirados e enquadrados no centro da graduação C do DNER, conforme mostra a Tabela 3.1. O ligante asfáltico utilizado foi um CAP-20, cujas características são mostradas na Tabela 3.2. 
Tabela 3.1: Distribuição granulométrica dos agregados do Programa I.

\begin{tabular}{ccc}
\cline { 2 - 3 } $\begin{array}{c}\text { Peneira } \\
\text { (mm) }\end{array}$ & \multicolumn{2}{c}{ Parcentagem passada } \\
\hline 19,1 & 100 & $\begin{array}{c}\text { Centro da Faixa C } \\
\text { (DNER) }\end{array}$ \\
12,7 & $85-100$ & 100 \\
9,52 & $75-100$ & 92,5 \\
4,76 & $50-85$ & 87,5 \\
2,00 & $30-75$ & 67,5 \\
0,42 & $15-40$ & 52,5 \\
0,177 & $8-30$ & 27,5 \\
0,074 & $5-10$ & 19 \\
\hline
\end{tabular}

Tabela 3.2: Caracterização do ligante asfáltico utilizado no Programa I.

\begin{tabular}{llc}
\hline \multicolumn{1}{c}{ Ensaio } & & CAP - 20 \\
\hline & $135^{\circ} \mathrm{C}$ & 194 \\
Viscosidade Saybolt-Furol (s) & $155^{\circ} \mathrm{C}$ & -- \\
& $177^{\circ} \mathrm{C}$ & 33 \\
Viscosidade absoluta & $(\mathrm{P})$ & 2480 \\
Ponto de Fulgor & $\left({ }^{\circ} \mathrm{C}\right)$ & 300 \\
Penetração $100 \mathrm{~g}, 5 \mathrm{~s}, 25^{\circ} \mathrm{C}$ & $(0,1 \mathrm{~mm})$ & 53 \\
Ponto de Amolecimento & $\left({ }^{\circ} \mathrm{C}\right)$ & 49 \\
Índice de susceptibilidade térmica & & 0,4 \\
\hline
\end{tabular}

\subsubsection{Parâmetros Marshall para definição do teor de trabalho}

Para a definição do teor de trabalho para a moldagem dos corpos-de-prova do Programa I foi executada uma dosagem Marshall, na energia equivalente ao tráfego pesado ( 75 golpes por face). A partir dos resultados dessa dosagem foi arbitrado o teor de trabalho $(5,5 \%)$ que levava, aproximadamente, a um volume de vazios igual a 4,0\%. Os parâmetros obtidos da dosagem para o teor de trabalho são reapresentados na Tabela 3.3. 
Tabela 3.3: resultados da Dosagem Marshall.

\begin{tabular}{llc}
\hline \multicolumn{2}{c}{ Parâmetros } & Resultados \\
\hline Teor de trabalho & $(\%)$ & 5,5 \\
Densidade Aparente & & 2,512 \\
Estabilidade & $(\mathrm{N})$ & 20.234 \\
Fluência & $(0,1 \mathrm{~mm})$ & 12 \\
Vv & $(\%)$ & 3,8 \\
RBV & $(\%)$ & 78,1 \\
\hline
\end{tabular}

\subsubsection{Produção dos corpos-de-prova}

A moldagem dos corpos-de-prova deu-se conforme o procedimento de dosagem descrito na AASHTO PP2. Nele é preconizada a permanência da mistura asfáltica não compactada em estufa por duas horas na temperatura de compactação. Para avaliar a influência do procedimento de moldagem na taxa de absorção de asfalto pelo agregado foram moldados corpos-de-prova sob diferentes condições (DNER e AASHTO PP2) e os resultados encontram-se apresentados na Tabela 3.4 .

Tabela 3.4: Taxas de absorção de asfalto em função do método de moldagem.

\begin{tabular}{lcc}
\hline \multicolumn{1}{c}{ Parâmetros } & \multicolumn{2}{c}{ Resultados } \\
\cline { 2 - 3 } & Marshall & AASHTO PP2 \\
\hline Teor de asfalto utilizado (\%) & 5,50 & 5,50 \\
Densidade do asfalto & 1,020 & 1,020 \\
DMM (ASTM D 2041) & 2,587 & 2,595 \\
Densidade efetiva do agregado & 2,841 & 2,851 \\
Densidade aparente do agregado & 2,805 & 2,805 \\
Absorção (\%) & 0,458 & 0,590 \\
Porosidade Total (\%) & 1,259 & 1,622 \\
\hline
\end{tabular}

Observando-se os resultados apresentados na Tabela 3.4 nota-se que a variação na absorção de asfalto em função do método de moldagem é muito pequena (pouco mais de 0,1\%). Assim, resolveu-se utilizar como teor de moldagem, para a execução desse programa de investigação, 
aquele obtido da dosagem Marshall apresentado anteriormente, ou seja, sem a correção devida à absorção.

\subsection{PROGRAMA II: AVALIAÇÃO DO EFEITO DE ALGUNS FATORES NA SUSCEPTIBILIDADE TÉRMICA DE MISTURAS ASFÁLTICAS DENSAS}

Este programa de pesquisa teve a finalidade de avaliar a influência de alguns fatores na susceptibilidade térmica de misturas asfálticas. Os fatores considerados foram:
a) Tipo de agregado: basalto, gabro e granito;
b) Tipo de asfalto: CAP 20 e CAP 40;
c) Teor de asfalto: ótimo - 0,5\%, ótimo e ótimo $+0,5 \%$;
d) Aditivo: com e sem cal;
e) Temperaturas de ensaio: $10^{\circ} \mathrm{C}, 25^{\circ} \mathrm{C}$ e $40^{\circ} \mathrm{C}$.

Para o desenvolvimento do estudo foi programado um experimento fatorial que considerou 36 condições experimentais ( 3 agregados, 2 asfaltos, 3 teores, com e sem aditivo). Para tanto foram moldados 108 corpos-de-prova (3 réplicas por condição de ensaio) segundo o procedimento da AASHTO PP2, que foram ensaiados nas três temperaturas anteriormente mencionadas (324 determinações de módulo de resiliência).

O monitoramento das mudanças nas misturas asfálticas provocadas pelo efeito das variáveis testadas foi feito a partir de ensaios módulo de resiliência por duas justificativas: primeiro para detectar a propriedade fundamental que reflete a rigidez das misturas asfálticas, e 
segundo, por se tratar de um ensaio não destrutivo e, por isso, permitir avaliar variações na propriedade numa mesma amostra, evitando o aumento dos erros experimentais. Assim foram determinados 324 valores de módulos de resiliência, que foram calculados segundo a proposta de cálculo da NCHRP 1-28 e 1-28A, sendo avaliados os valores dos módulos de resiliência total e instantâneo. Também foram avaliados a recuperação retardada e o atraso conforme definidos por Furlan (2006).

\subsubsection{Agregados}

\subsubsection{Tipos e distribuição granulométrica}

Foram utilizados três tipos de agregados nesta pesquisa:

- Basalto da região de São Carlos, fornecido pela Pedreira Bandeirantes Ltda.;

- Gabro da região de Limeira, fornecido pela Pedreira São Roque e;

- Granito da região de Valinhos, fornecido pela Pedreira São Jerônimo.

Os agregados provenientes das pedreiras foram lavados com água corrente até o material de diâmetro de 0,42mm (\#40), para eliminação do material fino aderido nas partículas. Para essa operação de lavagem utilizou-se um suporte improvisado com uma peneira e um tripé de equipamento topográfico adaptado para tal finalidade, conforme mostrado na Figura 3.1. 

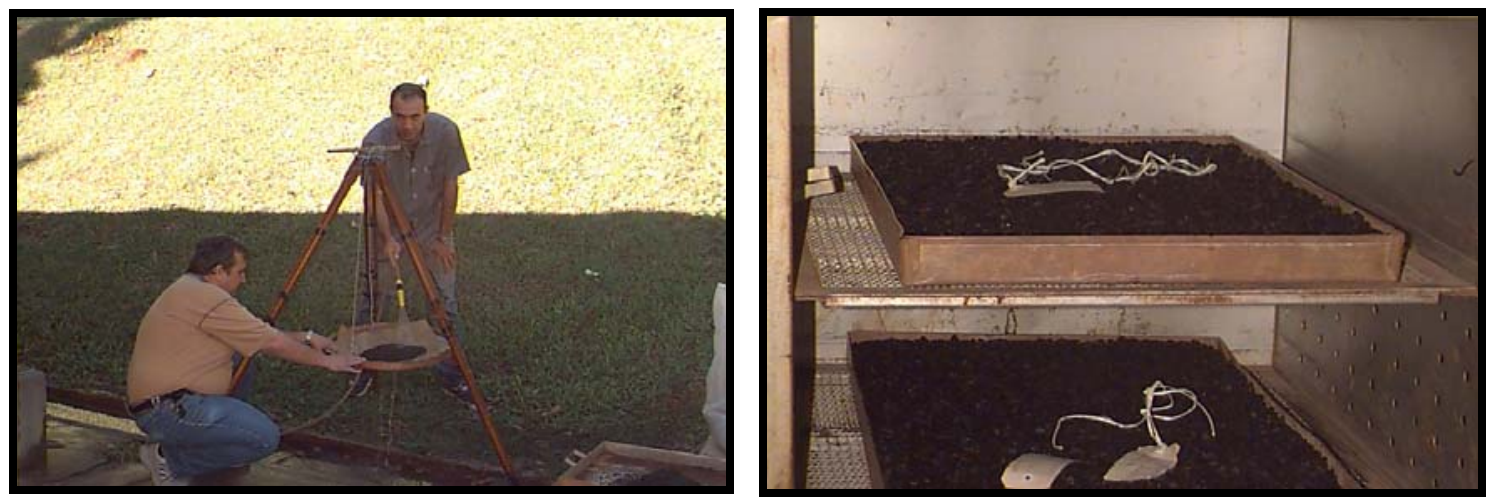

Figura 3.1: Procedimentos de lavagem e secagem dos agregados.

Após secarem, os agregados foram submetidos a ensaios de granulometria e, posteriormente, foram determinadas as porcentagens de cada fração para que as misturas se enquadrassem nos limites da faixa C do DNER-ES 313/97; conforme apresentado na Tabela 3.5.

Tabela 3.5: Composição granulométrica para enquadramento na faixa C do DNER.

\begin{tabular}{cccc}
\hline & Basalto & Gabro & Granito \\
\hline Pedra 1 & $15 \%$ & $10 \%$ & $12 \%$ \\
Pedrisco & $35 \%$ & $15 \%$ & $23 \%$ \\
Pó de Pedra 1 & $50 \%$ & $61 \%$ & $65 \%$ \\
Pó de Pedra 2 & & $14 \%$ & \\
\hline
\end{tabular}

Na Figura 3.2 são apresentadas as distribuições granulométricas para os três diferentes agregados, onde se pode observar que todas estão dentro dos limites da norma. 


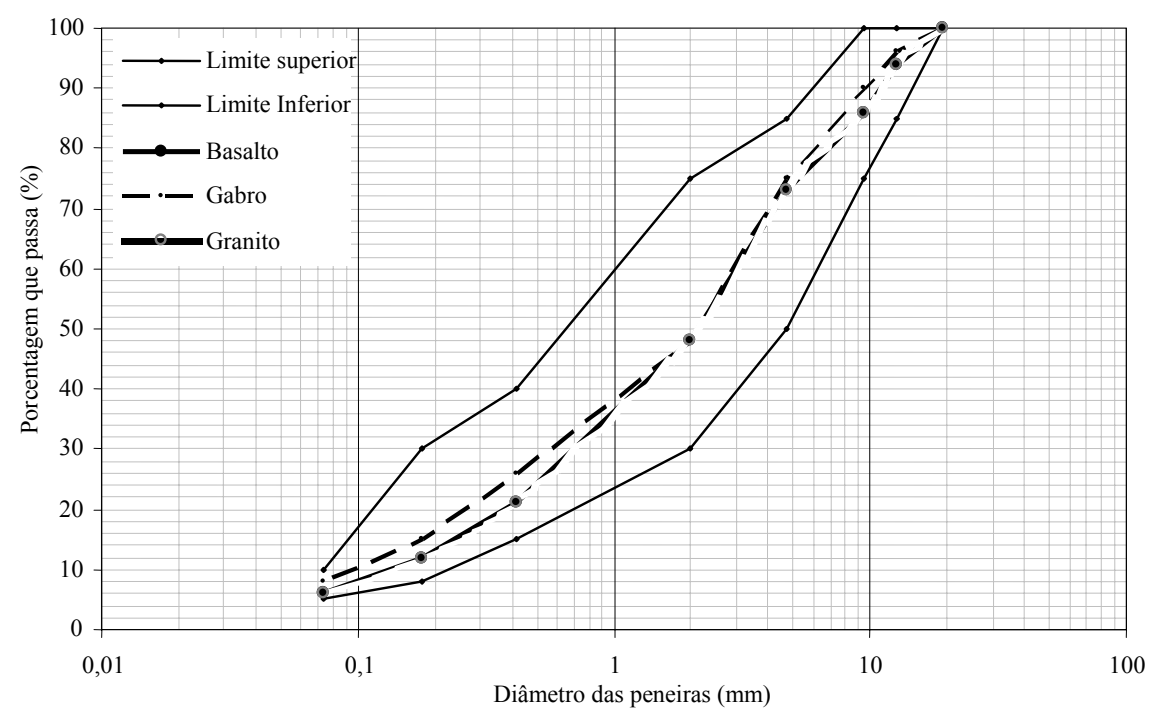

Figura 3.2: Distribuições granulométricas dos diferentes agregados enquadrados na faixa $\mathrm{C}$ do DNER.

\subsubsection{Características dos Agregados}

Foram executados ensaios de abrasão Los Angeles de acordo com o método de ensaio DNERME 35/98 (DNER, 1998b) em três graduações: B, C e D, tendo sido ensaiadas três amostras por graduação. As adesividades a ligantes betuminosos foram determinadas segundo o método DNER-ME 78/94 (DNER, 1994b) para agregado graúdo e segundo o método DNERME 79/94 (DNER, 1994c) para agregado miúdo. Já as densidades aparente e real dos agregados finos e grossos foram determinados segundo os procedimentos ASTM C-127 e a ASTM C-128. A Tabela 3.6 apresenta um resumo dos resultados desses ensaios de caracterização dos agregados. 
Tabela 3.6: Características dos agregados.

\begin{tabular}{cccc}
\hline Propriedade & Basalto & Gabro & Granito \\
\hline Adesividade (Riedel Weber) & Má & Má & Má \\
Adesividade (RRL Modificado) & Não satisfatória & Não satisfatória & Não satisfatória \\
Abrasão Los Angeles & $25 \%$ & $18 \%$ & $23 \%$ \\
Densidade Real & 2,872 & 2,832 & 2,608 \\
Densidade Aparente & 2,808 & 2,742 & 2,593 \\
\hline
\end{tabular}

Observando-se os resultados apresentados na Tabela 3.6 pode-se afirmar que:

a) quanto à abrasão, todos os agregados atendem à especificação, com desgastes inferiores a $40 \%$;

b) quanto às adesividades, nenhum dos agregados atende às especificações.

\subsubsection{Asfaltos}

\subsubsection{Tipos de asfalto}

Foram utilizados dois tipos de asfaltos: um CAP-20 e um CAP-40. Os asfaltos foram fornecidos pelo Centro de Pesquisas e Desenvolvimento (CENPES) da Petrobrás e produzidos na Refinaria de Duque de Caxias (REDUC), do Rio de Janeiro. Na Tabela 3.7 são apresentadas as suas características. 
Tabela 3.7: Características dos asfaltos.

\begin{tabular}{rcc}
\hline \multicolumn{1}{c}{ Propriedade } & CAP 20 & CAP 40 \\
\hline Penetração, $25^{\circ} \mathrm{C}, 5 \mathrm{~s}, 100 \mathrm{~g}(0,1 \mathrm{~mm})$ & 55 & 39 \\
Ponto de amolecimento $\left({ }^{\circ} \mathrm{C}\right)$ & 49 & 53 \\
Índice de susceptibilidade térmica & $-1,2$ & $-1,0$ \\
Viscosidade Saybolt-Furol a $135^{\circ} \mathrm{C}(\mathrm{s})$ & 177 & 261 \\
a $155^{\circ} \mathrm{C}(\mathrm{s})$ & 71 & 99 \\
a $175^{\circ} \mathrm{C}(\mathrm{s})$ & 34 & 45 \\
Viscosidade absoluta a $135^{\circ} \mathrm{C}(\mathrm{CP})$ & 370 & 545 \\
$155^{\circ} \mathrm{C}(\mathrm{CP})$ & 148 & 206 \\
$175^{\circ} \mathrm{C}(\mathrm{CP})$ & 72 & 94 \\
\hline
\end{tabular}

Observando-se os resultados apresentados na Tabela 3.7 nota-se que os dois asfaltos utilizados atendem as especificações vigentes para cimentos asfálticos para uso em pavimentação.

\subsubsection{Temperaturas para preparação e compactação dos corpos-de-prova}

De acordo com a especificação de serviço DNER-ES 313/97, a temperatura do ligante a ser utilizado na mistura deve variar de acordo com o tipo de CAP empregado; para o CAP convencional, a temperatura deve ser aquela em que o asfalto apresente uma viscosidade Saybolt-Furol na faixa de 75 a 150 segundos, indicando-se, preferencialmente, a viscosidade de 85 a 95 segundos. Entretanto, a temperatura do ligante não deve ser inferior a $107^{\circ} \mathrm{C}$ e nem exceder a $177^{\circ} \mathrm{C}$. Para a compactação da mistura, a norma DNER-ME 043/95 recomenda temperaturas em que o ligante apresente viscosidade Saybolt-Furol entre 125 e 155 segundos.

Nesta pesquisa adotou-se para a mistura do ligante aos agregados a temperatura do CAP correspondente à viscosidade Saybot-Furol de $85 \pm 10$ segundos e, para compactação, a especificada na norma DNER-ME 043/95. Para determinação das faixas de temperaturas para mistura e compactação foram elaborados dois gráficos que apresentam as variações das 
viscosidades em função da temperatura para os dois asfaltos (dados apresentados na Tabela 3.7) e, por interpolação, foram estabelecidas as temperaturas máximas e mínimas para essas operações, conforme pode ser visualizado nas Figuras 3.3 e 3.4, para o CAP 20 e CAP 40, respectivamente.

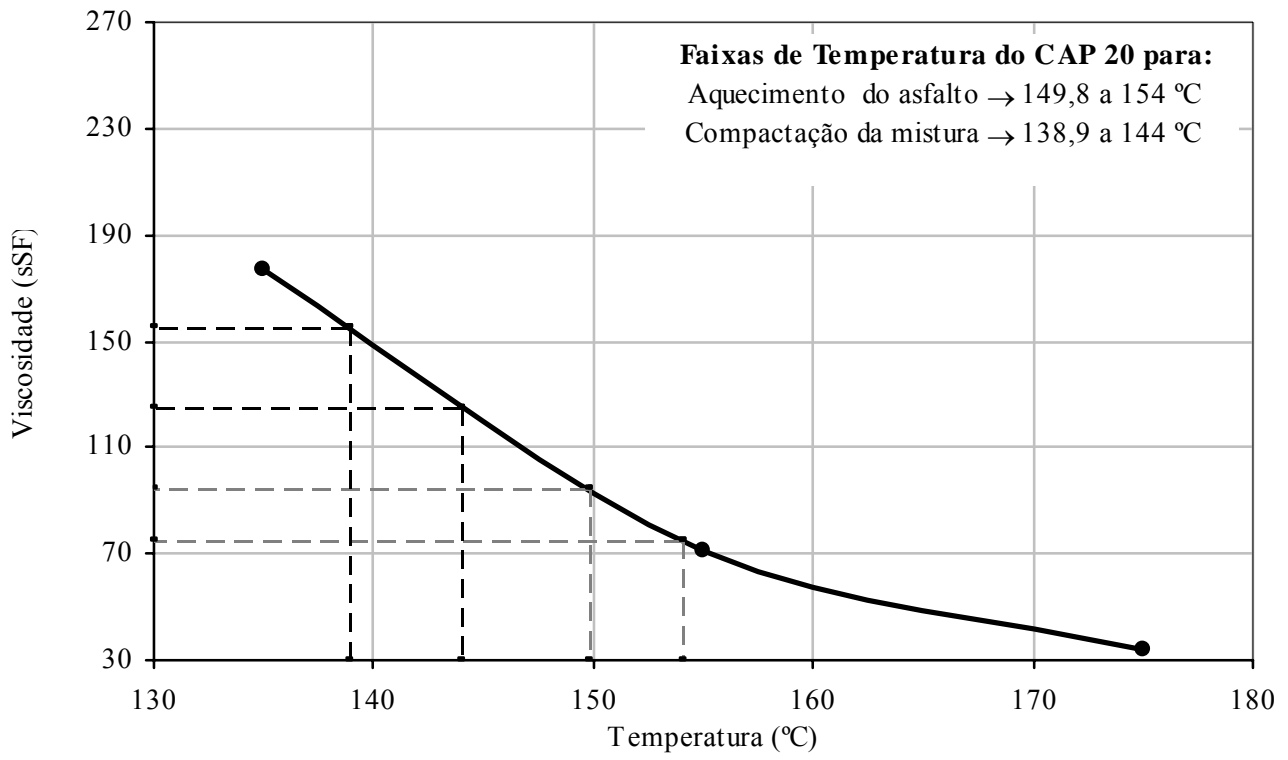

Figura 3.3: Viscosidade Saybolt-Furol versus temperatura para o CAP 20.

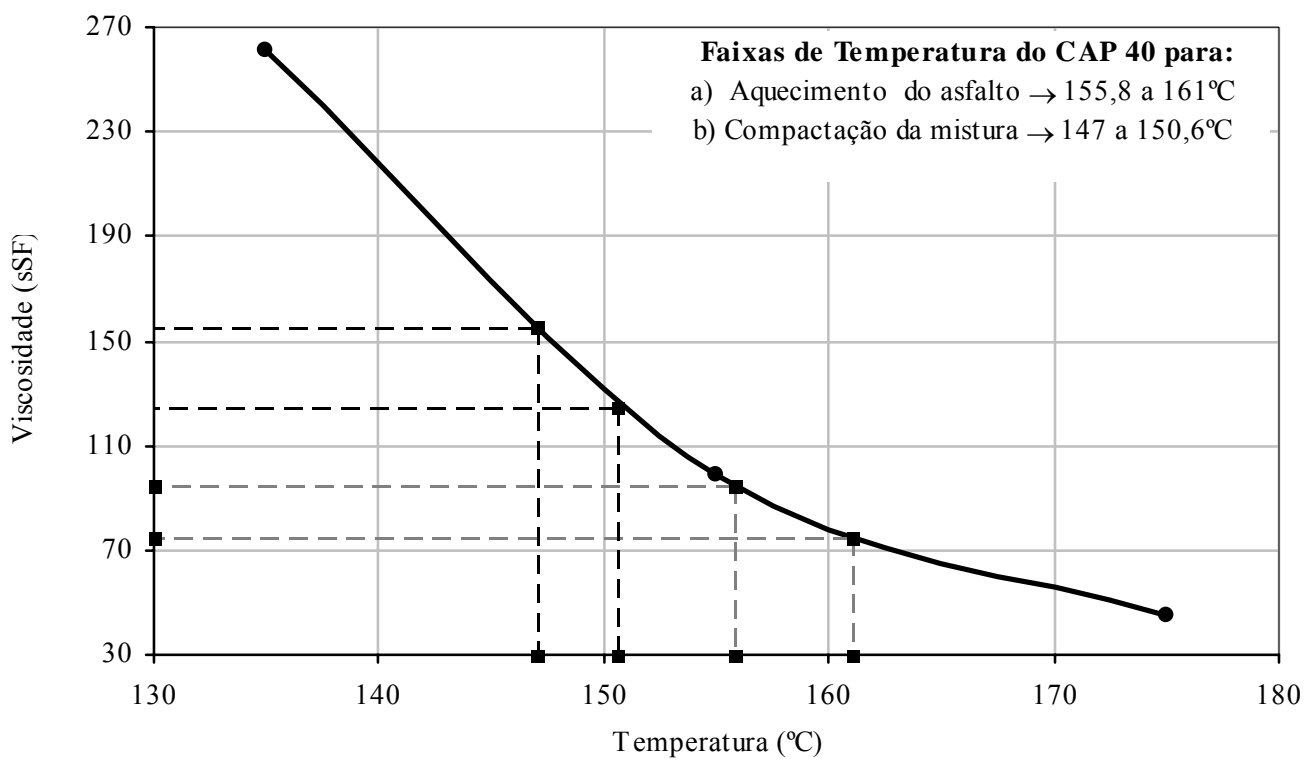

Figura 3.4: Viscosidade Saybolt-Furol versus temperatura para o CAP 40. 


\subsubsection{Cal}

A cal foi utilizada com a finalidade de estudar a sua influência nos valores do módulo de resiliência de misturas asfálticas, ou seja, se a sua presença eventualmente enrijece as misturas. A quantidade de cal adicionada à mistura asfáltica foi de $1 \%$, substituindo parte do material passante na peneira $200(0,075 \mathrm{~mm}$ de abertura). A Tabela 3.8 mostra as características da cal utilizada.

Tabela 3.8: Características da cal utilizada (Fonte: Supercal).

\begin{tabular}{lcc}
\hline \multicolumn{3}{c}{ Cal hidratada Cálcica(CH-I) } \\
\hline \multicolumn{1}{c}{ Ensaio } & Resultados & Especificação \\
\hline $\mathrm{CaO}$ & $70,86(\%)$ & 70 a $74(\%)$ \\
$\mathrm{MgO}$ & $1,08(\%)$ & 0,1 a $0,14(\%)$ \\
$\mathrm{Insolúvel} \mathrm{em} \mathrm{HCL}$ & - & 0,5 a $2,5(\%)$ \\
$\mathrm{Fe}_{2} \mathrm{O}_{3}+\mathrm{Al}_{2} \mathrm{O}_{3}$ & $0,40(\%)$ & 0,2 a $0,8(\%)$ \\
$\mathrm{Perda}_{3}$ ao fogo & $24,95(\%)$ & 23 a $27(\%)$ \\
$\mathrm{CO}_{2}$ & $3,23(\%)$ & 1,5 a $3,5(\%)$ \\
$\mathrm{SO}_{3}$ & $0,20(\%)$ & \\
$\%$ na \# 0,600mm & $0,45(\%)$ & \\
$\%$ na \# 0,075mm & $5,83(\%)$ & $<15(\%)$ \\
\hline
\end{tabular}

No projeto conjunto, que foi desenvolvido pelos três pesquisadores, a presença da cal teve por objetivos, além de propiciar a avaliação do eventual enrijecimento proporcionado às misturas, também verificar o reflexo da sua presença na vida de fadiga e na sensibilidade à água, temas esses que foram objeto de estudo dos outros dois integrantes do trabalho realizado em cooperação. 


\subsubsection{Misturas asfálticas}

\subsubsection{Preparação das massas asfálticas}

Para a produção das misturas, os agregados e o asfalto foram misturados em um equipamento adaptado que possibilita a produção de quantidade de massa para confecção de no mínimo 5 e no máximo 20 corpos-de-prova; esse equipamento é mostrado na Figura 3.5. Completado o processo de misturação, a mistura asfáltica foi despejada em uma bandeja e a quantidade de massa necessária para produção de cada corpo-de-prova foi separada em recipientes que, a seguir, foram colocados ordenadamente em uma estufa na temperatura de compactação, onde permaneceram por $2 \mathrm{~h}$ até a compactação propriamente dita. (conforme AASHTO PP2).

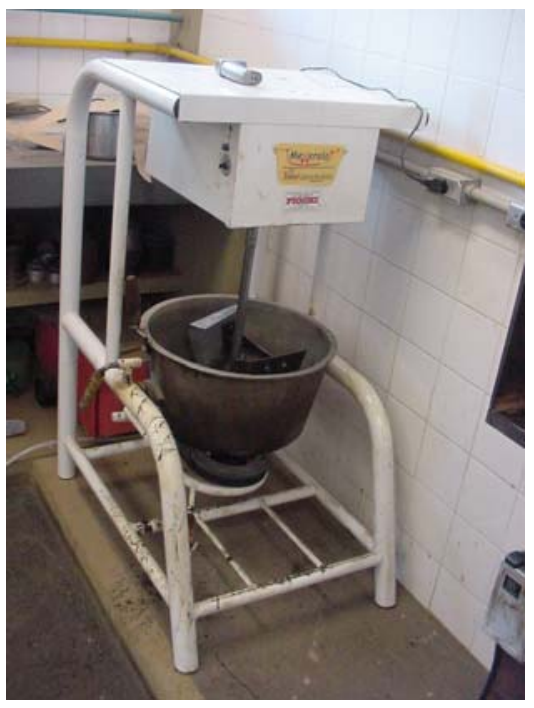

Figura 3.5: Equipamento adaptado para preparação de misturas asfálticas. 


\subsubsection{Dosagens Marshall}

As dosagens Marshall foram executadas segundo a NBR 12891 da ABNT. Para cada dosagem foram moldados 03 corpos-de-prova por teor de ligante, em 05 teores. Os resultados obtidos das dosagens das misturas asfálticas com CAP 20 estão apresentados na Tabela 3.9.

Tabela 3.9: Parâmetros Marshall das misturas asfálticas com CAP 20.

\begin{tabular}{|c|c|c|c|c|c|}
\hline \multicolumn{6}{|c|}{ Basalto } \\
\hline $\begin{array}{c}\text { Teor de asfalto } \\
(\%)\end{array}$ & $\begin{array}{c}\text { Densidade } \\
\text { aparente }\end{array}$ & $\begin{array}{c}\text { Estabilidade } \\
(\mathrm{N})\end{array}$ & $\begin{array}{l}\text { Fluência } \\
(0,1 \mathrm{~mm})\end{array}$ & $\begin{array}{l}\text { Vv } \\
(\%)\end{array}$ & $\begin{array}{l}\text { RBV } \\
(\%)\end{array}$ \\
\hline 4,50 & 2,496 & 18564 & 24,6 & 5,98 & 64,81 \\
\hline 5,00 & 2,507 & 19780 & 27,9 & 4,77 & 72,08 \\
\hline 5,50 & 2,512 & 19839 & 29,7 & 3,80 & 78,11 \\
\hline 6,00 & 2,512 & 18113 & 32,3 & 3,01 & 83,06 \\
\hline 6,50 & 2,509 & 15593 & 37,3 & 2,34 & 87,24 \\
\hline \multicolumn{6}{|c|}{ Gabro } \\
\hline $\begin{array}{c}\text { Teor de asfalto } \\
(\%)\end{array}$ & $\begin{array}{c}\text { Densidade } \\
\text { aparente }\end{array}$ & $\begin{array}{c}\text { Estabilidade } \\
\text { (N) }\end{array}$ & $\begin{array}{l}\text { Fluência } \\
(0,1 \mathrm{~mm})\end{array}$ & $\begin{array}{l}\mathrm{Vv} \\
(\%)\end{array}$ & $\begin{array}{l}\text { RBV } \\
(\%)\end{array}$ \\
\hline 4,50 & 2,395 & 18231 & 27,2 & 8,65 & 54,98 \\
\hline 5,00 & 2,436 & 21035 & 32,3 & 6,35 & 65,27 \\
\hline 5,50 & 2,467 & 22526 & 33,0 & 4,38 & 75,25 \\
\hline 6,00 & 2,465 & 22153 & 35,6 & 3,68 & 79,75 \\
\hline 6,50 & 2,452 & 21575 & 38,1 & 3,41 & 82,11 \\
\hline \multicolumn{6}{|c|}{ Granito } \\
\hline $\begin{array}{c}\text { Teor de asfalto } \\
\text { (\%) }\end{array}$ & $\begin{array}{c}\text { Densidade } \\
\text { aparente }\end{array}$ & $\begin{array}{c}\text { Estabilidade } \\
\text { (N) }\end{array}$ & $\begin{array}{l}\text { Fluência } \\
(0,1 \mathrm{~mm})\end{array}$ & $\begin{array}{l}\text { Vv } \\
(\%)\end{array}$ & $\begin{array}{l}\text { RBV } \\
(\%)\end{array}$ \\
\hline 4,50 & 2,269 & 13710 & 27,2 & 6,90 & 59,21 \\
\hline 5,00 & 2,280 & 14082 & 30,5 & 5,75 & 66,04 \\
\hline 5,50 & 2,296 & 14916 & 32,3 & 4,42 & 73,73 \\
\hline 6,00 & 2,292 & 14602 & 33,8 & 3,89 & 77,62 \\
\hline 6,50 & 2,286 & 12955 & 36,3 & 3,47 & 80,77 \\
\hline
\end{tabular}

De acordo com os resultados das dosagens Marshall, foi definido o teor de asfalto de trabalho igual a 5,5\% para as três misturas asfálticas com CAP 20. O critério adotado para a fixação dos teores de trabalho foi a obtenção de volumes de vazios em torno de $4 \%$. Em todas as 
misturas esse valor levou a valores de estabilidade e densidade próximos aos valores máximos das curvas (Apêndice I). Para as misturas com CAP 40, assumiram-se teores de asfalto de trabalho iguais aos obtidos para as misturas com CAP 20, por duas razões, a saber:

a) as características das curvas granulométricas dos agregados e, conseqüentemente, as superfícies específicas, mantiveram-se as mesmas, podendo-se esperar um consumo de asfalto similar;

b) as temperaturas normalizadas para os procedimentos de preparação, misturação e compactação (DNER-ME 043/95) implicam em faixas de viscosidade similares para asfaltos convencionais.

\subsubsection{Absorção de Asfalto pelo Agregado}

Para a determinação da absorção de asfalto pelos agregados foi utilizado o método da ASTM D 4021. Esse método é utilizado para determinar a "densidade máxima medida" (DMM) e, a partir dela, determinar a densidade efetiva do agregado e a taxa absorção de asfalto.

A determinação das absorções de asfalto pelos agregados foi executada principalmente pelo fato de se ter moldado os corpos-de-prova segundo o AASHTO PP2 (2 horas na estufa) e que cada agregado, de acordo com as suas características de porosidade e níveis de absorção, interagem com o ligante de forma particular. Por isso, foram realizados os ensaios de determinação da taxa de absorção de asfalto com o objetivo de corrigir o teor de trabalho em relação à obtida da moldagem Marshall. Na Tabela 3.10 são apresentados os resultados das absorções dos agregados para os dois tipos de asfaltos utilizados na pesquisa. 
Tabela 3.10: Taxas de absorção de asfalto pelos agregados.

\begin{tabular}{cccc}
\hline \multicolumn{4}{c}{ CAP 20 } \\
\hline Condição AASHTO PP2 & Basalto & Gabro & Granito \\
\hline Densidade máxima medida & 2,609 & 2,556 & 2,401 \\
Densidade efetiva & 2,869 & 2,802 & 2,606 \\
Absorção de asfalto (\%) & 0,6 & 0,8 & 0,2 \\
\hline \multicolumn{5}{c}{ CAP 40 } \\
\hline Condição AASHTO PP2 & Basalto & Gabro & Granito \\
\hline Densidade máxima medida & 2,609 & 2,552 & 2,394 \\
Densidade efetiva & 2,869 & 2,796 & 2,597 \\
Absorção de asfalto (\%) & 0,6 & 0,9 & 0,3 \\
\hline
\end{tabular}

Observando-se os resultados apresentados na Tabela 3.10 nota-se diferenças significativas nas taxas de absorção de asfalto pelos agregados de basalto e de gabro em relação ao de granito para os dois asfaltos utilizados.

Dependendo da porosidade do agregado, o "condicionamento" do AASHTO PP2 pode permitir absorção de asfalto, uma vez que na temperatura de compactação o ligante apresenta viscosidade baixa, o que propicia a penetração através dos poros dos agregados, causando uma diminuição na espessura da película de asfalto que, dentre outros efeitos, torna a mistura mais sensível ao clima assim como ao envelhecimento do ligante devido ao tempo de exposição a altas temperaturas.

Com o objetivo de manter os volumes de vazios compatíveis com aqueles encontrados durante o processo de dosagem inicial, foi adotada uma correção no teor de asfalto em função da absorção que cada agregado apresentou quando submetido aos diferentes procedimentos de moldagem. Assim, os teores de asfalto utilizados nas misturas moldadas segundo o procedimento da AASHTO PP2 foram os descritos na Tabela $3.5(5,5 \%)$ (teores de trabalho para CAP 20 e CAP 40) acrescidos das absorções obtidas para cada agregado descritos na Tabela 3.10. 
Por exemplo, o basalto apresentou uma taxa de absorção de $0.6 \%$ para o CAP 20 , então, a quantidade de CAP 20 que foi adicionada na moldagem, seguindo o procedimento AASHTO PP2, foi de 6,1\% $(5,5+0,6)$, o que supostamente permitiu manter o teor efetivo de asfalto igual ao de projeto determinado na dosagem Marshall inicial. Com essa medida corretiva foi possível manter os parâmetros volumétricos muito próximos aos da dosagem original para todas as combinações das misturas asfálticas.

\subsection{ENSAIOS REALIZADOS}

Na avaliação mecânica das misturas asfálticas foi utilizado, basicamente, o ensaio de módulo de resiliência, além do o ensaio de resistência à tração por compressão diametral, cuja finalidade foi a de complementar a caracterização das misturas.

\subsubsection{Módulo de resiliência}

Para possibilitar o estudo do comportamento quanto ao enrijecimento das misturas asfálticas ao longo do tempo (Programa I) e o efeito de alguns fatores na suscetibilidade térmica nas misturas foi escolhido o ensaio de módulo de resiliência, por se tratar de um ensaio não destrutivo e que permite avaliar a variação da propriedade no mesmo corpo-de-prova.

Para evitar eventuais danos aos corpos-de-prova provocados pelos ensaios, estabeleceu-se uma seqüência de execução em relação às temperaturas. Procedeu-se os ensaios sempre a partir da temperatura mais baixa, correspondente aos valores mais altos de módulo, para as 
temperaturas mais altas, onde as misturas são mais deformáveis e mais suscetíveis a deformações permanentes.

Os módulos de resiliência foram determinados para as temperaturas pré-fixadas e o procedimento consistiu, simplificadamente, da aplicação de 100 ciclos de carregamento de magnitude fixa, com 1,0 s de duração, sendo cada ciclo constituído por um período carregamento de $0,1 \mathrm{~s}$ e um período de repouso de 0,9s. A Figura 3.6 mostra um esquema de um equipamento para o ensaio de determinação do módulo de resiliência, semelhante ao utilizado nesta pesquisa.

Para a execução do ensaio do módulo de resiliência foi arbitrado como período de condicionamento os primeiros 30 a 40 ciclos de carregamento, e como ensaio propriamente, os 70 a 60 ciclos restantes. Esta consideração propiciou uma diminuição da variação dos valores do módulo de resiliência ao longo do ensaio, uma vez que a resposta visco-elástica do asfalto às primeiras aplicações de carga pode ser afetada por alguma acomodação do corpode-prova e/ou ainda alguma variação fora dos padrões dos desvios detectados após esta “estabilização". Assim, o estabelecimento do início efetivo do ensaio a partir de 30 a 40 ciclos de carregamento teve a finalidade de reduzir o desvio padrão em relação aos valores dos módulos a um patamar inferior a 5\% dos valores médios dos módulos de resiliência, assegurando homogeneidade e melhora na qualidade dos resultados. 


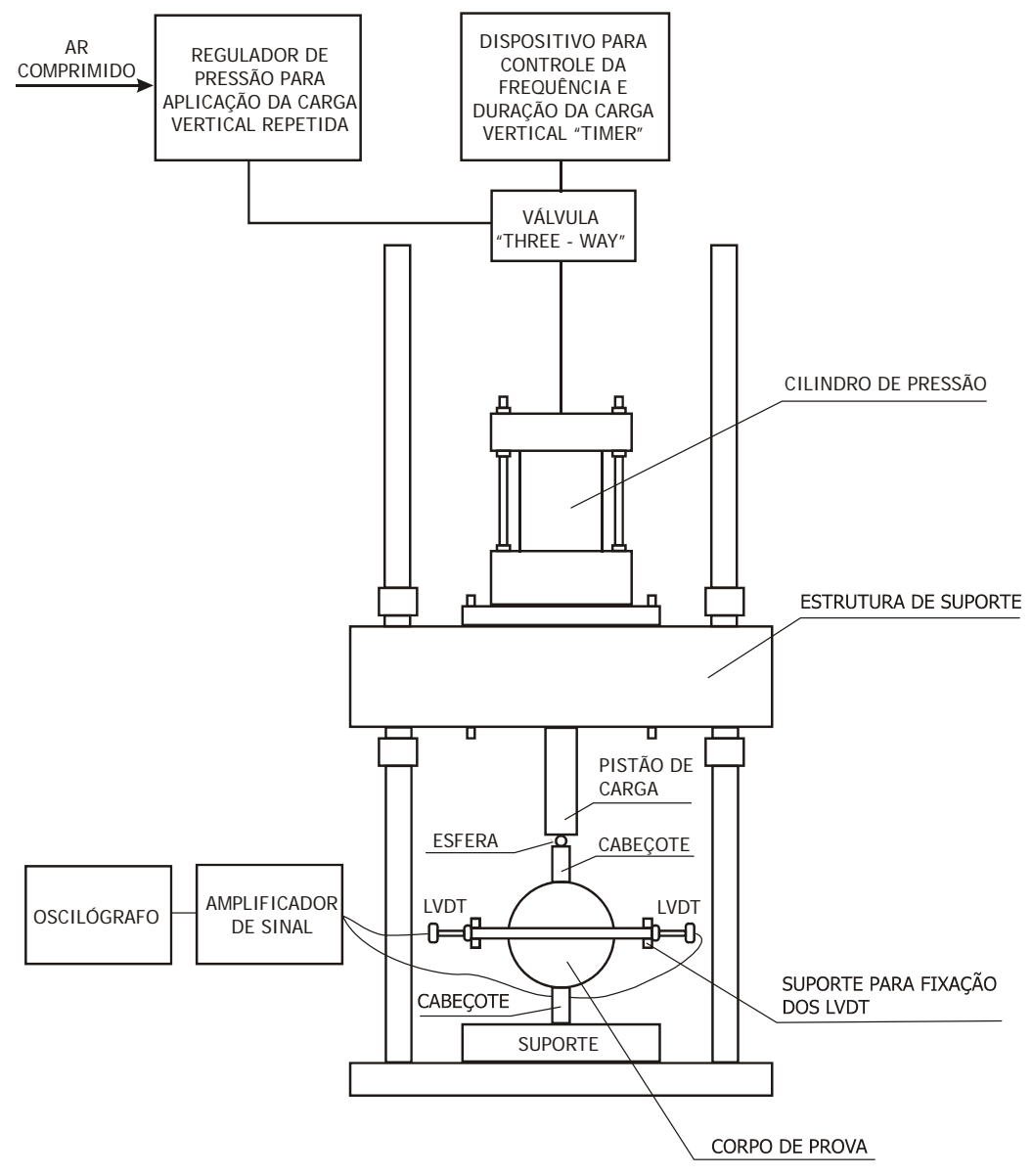

Figura 3.6: Esquema de equipamento para determinação do módulo de resiliência.

Como parte deste estudo avaliou a variação do módulo de resiliência ao longo do tempo nos mesmos corpos-de-prova, foi conveniente fixar um valor de deformação inicial para os ensaios, desta forma a carga inicial era variada para que produzisse deformações da ordem de 2,5 a 3,0 milésimos de milímetros. Apesar de não obedecer ao método de ensaio vigente, o procedimento ora adotado foi necessário com o intuito de preservar a integridade do material, sem, por exemplo, propiciar o aparecimento de sinais de fadiga. Para o cálculo dos valores dos módulos de resiliência foi utilizada a expressão 3.1, oriunda da norma DNER ME 133/94.

$$
M R=\frac{F}{\Delta h}(0,9976 \mu+0,2692)
$$


Em que:

$M R$ é o módulo de resiliência em $\mathrm{MPa}$;

F é a carga vertical repetida aplicada diametralmente ao corpo-de-prova, em N;

$\Delta$ é o deslocamento total (correspondente à deformação elástica do corpo-de-prova na direção perpendicular à aplicação da carga), em mm;

h é a altura do corpo-de-prova, em mm;

$\mu$ é o coeficiente de Poisson, assumido como igual a 0,35 .

Para determinação dos deslocamentos totais e instantâneos utilizados nos cálculos dos valores dos módulos totais e instantâneos foram utilizados os procedimentos contidos nas normas AASSHTO TP-31 e NCHRP Project 1-28, à semelhança do utilizado em Furlan (2006). Assim, foram sempre calculados quatro valores de módulos de resiliência, a saber: módulos de resiliência total e instantâneo segundo as normas AASHTO TP-31 e segundo a NCHRP Project 1-28.

\subsubsection{Resistência à tração}

As resistências à tração foram determinadas segundo o método de ensaio DNER ME 138/94, somente para a temperatura de $25^{\circ} \mathrm{C}$, uma vez que não foram produzidos corpos-de-prova em número suficiente para a execução desse ensaio nas três temperaturas contempladas no projeto, já que esse ensaio destrói o corpo-de-prova, diferente do que acontece no ensaio de módulo de resiliência, que permite o reaproveitamento para uso sob outras condições.

A resistência à tração foi calculada segundo a expressão 3.2. 


$$
R_{T}=\frac{2 F}{\pi d h}
$$

Em que:

$R_{T}$ é a resistência à tração, em $\mathrm{MPa}$;

F é a carga de ruptura, em N;

d é o diâmetro médio do corpo-de-prova, em mm;

h é a altura média do corpo-de-prova, em mm. 


\section{CAPÍTULO 4 APRESENTAÇÃo E DISCUSSÃo DOS RESULTADOS}

\subsection{CONSIDERAÇÕES INICIAIS}

A seguir são apresentados os principais resultados obtidos dos dois programas experimentais implementados nessa pesquisa, conforme descrito no Capítulo 3, assim como as eventuais características dos corpos-de-prova que foram utilizados em cada experimento. Outras informações podem ser obtidas nos apêndices.

\subsection{PROGRAMA I: AVALIAÇÃO DOS EFEITOS DAS CONDIÇÕES AMBIENTAIS NO ENRIJECIMENTO DE MISTURAS ASFÁLTICAS DENSAS}

Cabe relembrar que este programa experimental teve a finalidade de avaliar os efeitos que as condições ambientais exercem no valor do módulo de resiliência de misturas asfálticas densas ao longo do período de estocagem. Foram consideradas cinco condições ambientais distintas, a saber: ao ar e à luz (AAAL), ao ar e sem luz (AASL), sob baixa pressão atmosférica e à luz (AVAL), sob baixa pressão atmosférica e sem luz (AVSL) e ao clima e às intempéries (CLIMA). 
Os valores médios dos módulos de resiliência (média de 4 corpos-de-prova) dos cinco grupos submetidos às diferentes condições ambientais ao longo do tempo ( 0 a 42 dias) são apresentados na Tabela 4.1.

Observando-se a Tabela 4.1 nota-se que, de uma maneira geral, que houve aumento do módulo de resiliência ao longo do tempo, sendo o ganho mais pronunciado nos primeiros períodos de observação.

Tabela 4.1: Valores médios de MR dos grupos ao longo do tempo.

\begin{tabular}{|c|c|c|c|c|c|c|c|c|c|}
\hline \multirow[b]{2}{*}{ Grupo } & \multicolumn{3}{|c|}{ Parâmetros } & \multicolumn{6}{|c|}{ Período de exposição (dias) } \\
\hline & $\begin{array}{c}\text { Vv } \\
\text { Médio } \\
\text { (\%) }\end{array}$ & $\begin{array}{c}\text { Desv. } \\
\text { Padrão } \\
\text { Vv }\end{array}$ & MR & $\mathbf{0}$ & 7 & 14 & 21 & 35 & 42 \\
\hline \multirow{3}{*}{ AAAL } & \multirow{3}{*}{3,6} & \multirow{3}{*}{0,7} & MR (MPa) & 7877 & 11521 & 13475 & 13008 & 13360 & 14311 \\
\hline & & & Desv. Padrão (MPa) & 1742 & 1999 & 1887 & 1268 & 1047 & 1342 \\
\hline & & & Taxa de desv. do grupo (\%) & 22 & 17 & 14 & 10 & 8 & 9 \\
\hline \multirow{3}{*}{ AASL } & \multirow{3}{*}{4,0} & \multirow{3}{*}{0,6} & MR (MPa) & 7920 & 13292 & 13400 & 13223 & 13085 & 14175 \\
\hline & & & Desv. Padrão (MPa) & 1748 & 1768 & 1102 & 1608 & 2000 & 2330 \\
\hline & & & Taxa de desv. do grupo (\%) & 22 & 13 & 8 & 12 & 15 & 16 \\
\hline \multirow{3}{*}{ AVAL } & \multirow{3}{*}{3,4} & \multirow{3}{*}{0,4} & MR (MPa) & 7885 & 10448 & 11513 & 13979 & 13363 & 13134 \\
\hline & & & Desv. Padrão (MPa) & 1317 & 3291 & 2253 & 2702 & 2255 & 1465 \\
\hline & & & Taxa de desv. do grupo (\%) & 17 & 31 & 20 & 19 & 17 & 11 \\
\hline \multirow{3}{*}{ AVSL } & \multirow{3}{*}{4,0} & \multirow{3}{*}{0,6} & $\mathrm{MR}(\mathrm{MPa})$ & 7580 & 10103 & 13880 & 12358 & 12407 & 13588 \\
\hline & & & Desv. Padrão (MPa) & 650 & 1420 & 2094 & 1577 & 2020 & 137 \\
\hline & & & Taxa de desv. do grupo (\%) & 9 & 14 & 15 & 13 & 16 & 1 \\
\hline \multirow{3}{*}{ CLIMA } & \multirow{3}{*}{3,5} & \multirow{3}{*}{1,1} & $\mathrm{MR}(\mathrm{MPa})$ & 7757 & 8321 & 11286 & 12161 & 12463 & 14034 \\
\hline & & & Desv. Padrão (MPa) & 551 & 1187 & 586 & 957 & 1505 & 1625 \\
\hline & & & Taxa de desv. do grupo (\%) & 7 & 14 & 5 & 8 & 12 & 12 \\
\hline
\end{tabular}

A Figura 4.1 ilustra o efeito da exposição à luz, ao longo do tempo, nos valores de módulo de resiliência dos corpos-de-prova que ficaram ao ar (condições "ao ar à luz" e "ao ar sem luz"). As curvas têm comportamentos muito parecidos e exibem aumento significativo nos primeiros 14 dias e depois tendem a uma desaceleração do processo de enrijecimento. Para esse período de exposição, a mistura apresentou ganho de $80 \%$ do módulo inicial, aproximadamente, sendo que $70 \%$ deram-se no primeiro terço do período. Aparentemente, os corpos-de-prova enrijeceram devido ao tempo e não pela condição climática, uma vez que na 
maioria do intervalo as curvas quase se sobrepõem. Assim, parece que o fator iluminação (AL e SL) pouco influenciou na variação do módulo de resiliência.

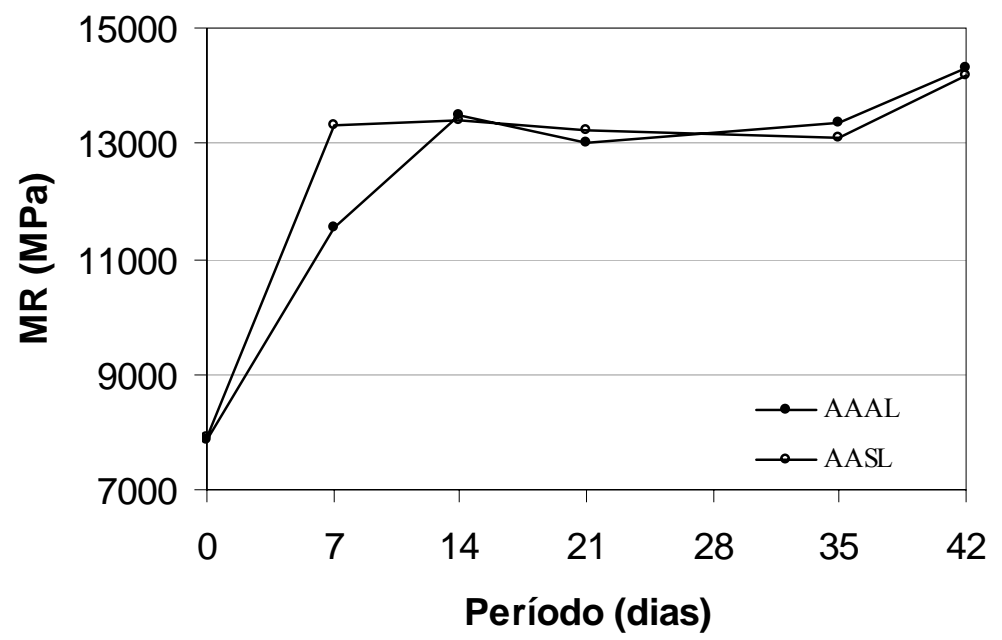

Figura 4.1: Efeito do fator "iluminação" na variação do MR ao longo do tempo para condições ambientais "ao ar".

Na Figura 4.2 são apresentadas as curvas de enrijecimento para misturas mantidas sob baixa pressão (ao vácuo) com e sem exposição à luz (AVAL e AVSL). Ainda que os resultados sejam mais dispersos que os apresentados anteriormente, nota-se o mesmo tipo de comportamento exibido na Figura 4.1. Há um aumento significativo do módulo de resiliência até, aproximadamente, metade do período de observação (21 dias). Em termos de variação absoluta, os módulos de resiliência obtidos no final do período são de cerca de $80 \%$ maiores que os iniciais. 


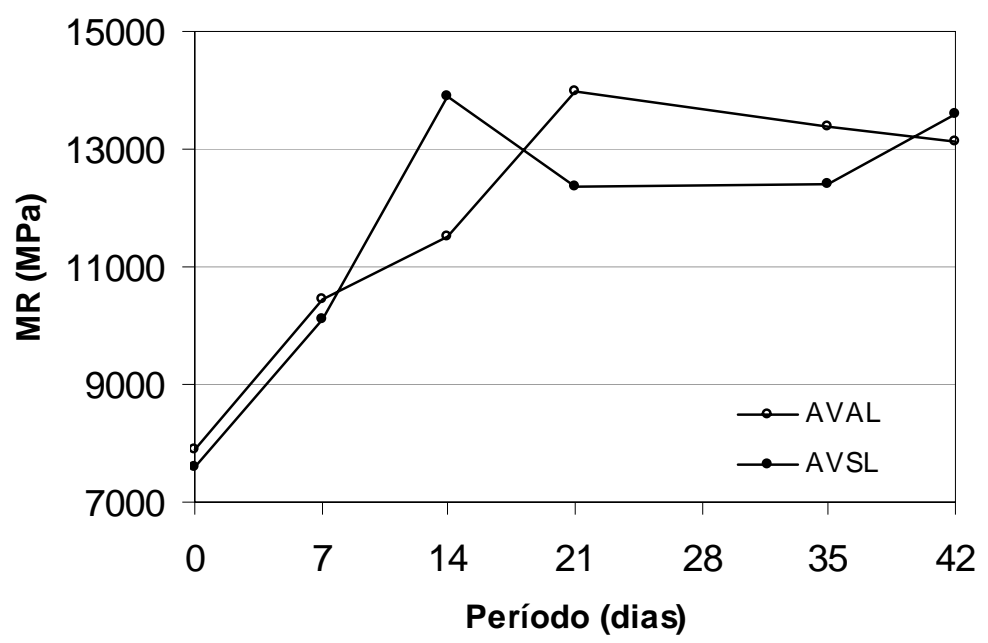

Figura 4.2: Efeito de fator "iluminação" na variação do MR ao longo do tempo para condições ambientais "ao vácuo".

As condições AAAL, AASL, AVAL e AVSL produziram tendências de comportamento e taxas de variação do módulo de resiliência muito similares, mas deve ser salientado que, aparentemente, um pequeno retardamento no enrijecimento foi verificado para grupos "ao vácuo" (AV), para os quais os períodos de enrijecimento acelerado são, aproximadamente, $50 \%$ maiores que os dos grupos "ao ar" (AA). Ou seja, enquanto as misturas asfálticas mantidas sob baixa pressão atmosférica (AV) levaram 21 dias para atingirem o (chamado) “período de desaceleração/estabilização" do módulo de resiliência, foi necessário um período de apenas 14 dias para que as misturas asfálticas submetidas às condições AA atingissem esse patamar.

A variação do módulo de resiliência do grupo de corpos-de-prova submetido ao clima e às intempéries é mostrada na Figura 4.3. Nela se observa que os valores médios finais dos módulos de resiliência são da mesma ordem de grandeza dos valores dos outros grupos, aproximadamente $80 \%$ maior que o valor inicial. Contudo, a forma como a curva de enrijecimento se desenvolve parece ser mais gradual, não havendo um patamar bem definido 
de desaceleração, como os observados para os outros grupos, sugerindo que as ações do clima poderiam ainda não ter se manifestado completamente durante o período de observação.

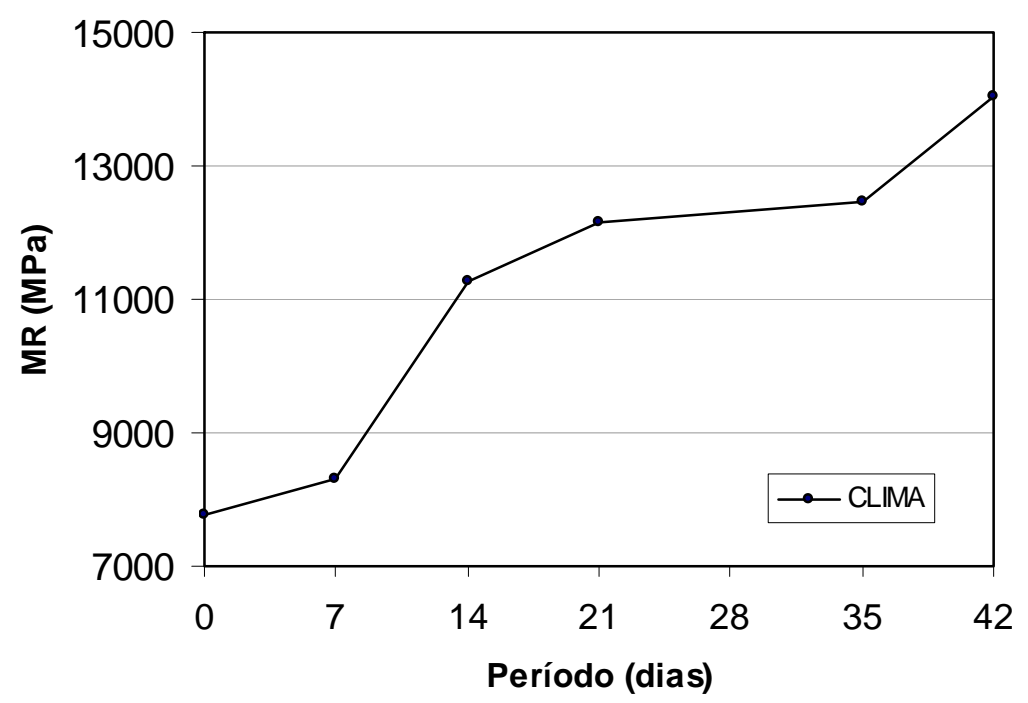

Figura 4.3: Variação do MR ao longo do tempo para a condição ambiental "CLIMA".

Para avaliar a significância dos fatores "ambiente" e "tempo" nos valores dos módulos de resiliência das misturas asfálticas, foi feita uma avaliação estatística baseada na análise de variância (ANOVA). Na Tabela 4.2 é apresentado o resumo dos resultados dos tratamentos estatísticos, onde estão os fatores considerados em cada tratamento e suas significâncias. De maneira geral, nota-se que o período de exposição produziu efeito significativo para todas as condições testadas, já a condição ambiental somente produziu efeito significativo no tratamento que considerou os fatores relacionados à iluminação (AL, SL e CLIMA).

O efeito da condição climática é mostrado na Figura 4.4, onde se nota que os valores médios dos módulos de resiliência, considerado todo o período de observação, variam pouco em função da condição climática, sendo que sob as condições "artificiais" (AA, AV, AL e SL) os valores médios dos móduloss de resiliência exibem pequena variação entre eles. Os menores valores são exibidos pelos corpos-de-prova do grupo CLIMA. 
Tabela 4.2: Significância dos fatores na variação do MR.

\begin{tabular}{lcl}
\hline & Tratamento 1 & \\
\hline Fatores & & Significância \\
Exposição ao ar & AA e AV & não \\
$\begin{array}{l}\text { Exposição à luz } \\
\text { Tempo }\end{array}$ & AL e SL & não \\
& 0 a 42 & sim \\
\hline \multicolumn{3}{c}{ Tratamento 2 } \\
\hline Fatores & AA, AV, AL, SL e CLIMA & não \\
Variações climáticas & 0 a 42 & sim \\
Tempo & & \\
\hline \multicolumn{3}{c}{} \\
\hline Fatores & Tratamento 3 \\
Exposição à luz & AL, SL e CLIMA & Significância \\
Tempo & 0 a 42 & sim \\
\hline
\end{tabular}

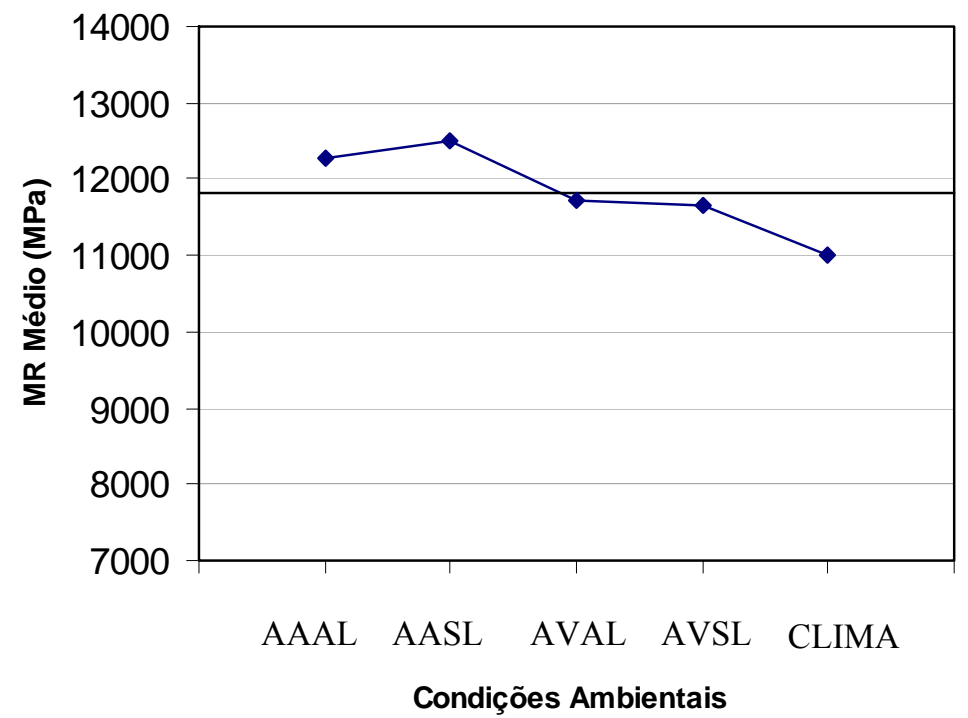

Figura 4.4: Efeito do fator condição ambiental nos valores médios dos módulos de resiliência.

Como já havia sido mencionado anteriormente, o efeito do período de exposição é bastante pronunciado e a análise estatística serviu para ratificar essas observações acerca dos comportamentos das curvas de enrijecimento. Assim, o período de exposição é significativo na variação dos valores médios dos módulos de resiliência para todas as amostras, independente do tipo de condição ambiental, como se nota na curva apresentada na Figura 4.5 . 


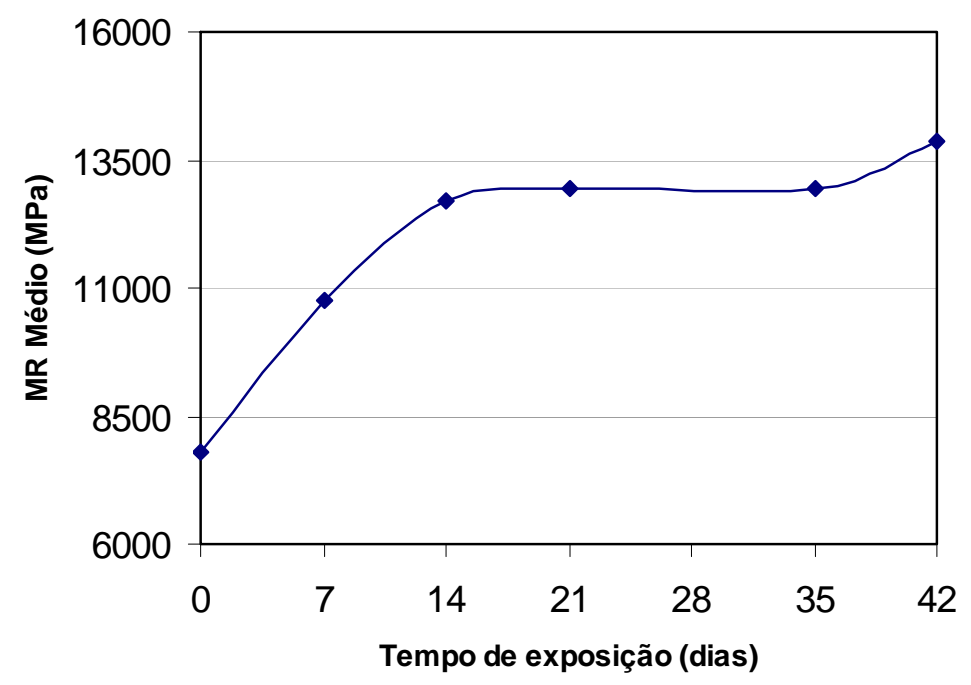

Figura 4.5: Efeito do tempo de exposição nos valores médios dos módulos de resiliência.

\subsection{PROGRAMA II: AVALIAÇÃO DO EFEITO DE ALGUNS FATORES NA SUSCEPTIBILIDADE TÉRMICA DE MISTURAS ASFÁLTICAS DENSAS}

\subsubsection{Considerações iniciais}

Este programa de pesquisa teve a finalidade de avaliar a influência de alguns fatores na susceptibilidade térmica de misturas asfálticas, que foi avaliada por intermédio dos valores do módulo de resiliência. Os fatores considerados foram: tipo de agregado (basalto, gabro e granito), tipo de asfalto (CAP 20 e CAP 40), teor de asfalto $(5,0 \%, 5,5 \%$ e $6,0 \%)$, presença de aditivo (com e sem cal) e temperaturas de ensaio $\left(10,25\right.$ e $\left.40^{\circ} \mathrm{C}\right)$.

Cabe ressaltar que no caso da variável teor de asfalto foram feitas correções dos teores “ótimos”, baseadas nas absorções de asfalto pelos agregados, como mencionado no capítulo 3, com a finalidade de manter os teores efetivos de asfalto compatíveis com os obtidos nas dosagens preliminares e, dessa forma, produzir corpos-de-prova com as características 
volumétricas almejadas. Assim, quando no texto aparecerem teores de asfalto iguais a 5,0\%, $5,5 \%$ e $6,0 \%$, estes se referem a teores efetivos de asfalto, ou seja, os corpos-de-prova foram produzidos com esses teores acrescidos de $0,6 \%, 0,8 \%$ e $0,2 \%$ para os agregados basalto, gabro e granito, respectivamente.

\subsubsection{Características dos corpos-de-prova}

A seguir serão apresentadas algumas características dos corpos-de-prova tais como volumes de vazios, resistência à tração obtida a $25^{\circ} \mathrm{C}$, módulo de resiliência total calculado segundo o procedimento da AASHTO e relação entre módulo de resiliência e resistência à tração, para a temperatura de $25^{\circ} \mathrm{C}$. Outras características poderão ser encontradas nos apêndices.

\subsubsection{Volumes de vazios}

Na Tabela 4.3 são apresentados os volumes de vazios dos corpos-de-prova que foram utilizados no Programa II. Observando-se os resultados apresentados nessa tabela nota-se que, de uma maneira geral, os desvios-padrão não são muito grandes em relação aos valores das

médias, indicando que as moldagens foram bem controladas, produzindo corpos-de-prova com padrões similares. Observa-se também, de uma maneira geral, que os corpos-de-prova oriundos do agregado basalto apresentam volumes de vazios menores, quando comparados para mesmos teores de asfalto, que os de granito e de gabro. 
Tabela 4.3: Volumes de vazios médios e desvios-padrão dos corpos-de-prova utilizados no Programa II.

\begin{tabular}{|c|c|c|c|c|c|c|c|c|}
\hline & & & \multicolumn{2}{|c|}{ Basalto } & \multicolumn{2}{|c|}{ Granito } & \multicolumn{2}{|c|}{ Gabro } \\
\hline & \multicolumn{2}{|c|}{ Teor de Asfalto } & sem cal & com cal & sem cal & com cal & sem cal & com cal \\
\hline \multirow{6}{*}{ CAP 20} & \multirow{2}{*}{5,0} & Média & 4.68 & 4.94 & 5.57 & 5.66 & 6.32 & 6.24 \\
\hline & & Desvio Padrão & 0.15 & 0.10 & 0.17 & 0.19 & 0.13 & 0.26 \\
\hline & \multirow{2}{*}{5,5} & Média & 3.81 & 3.90 & 4.33 & 4.14 & 4.20 & 4.10 \\
\hline & & Desvio Padrão & 0.12 & 0.08 & 0.07 & 0.04 & 0.02 & 0.10 \\
\hline & \multirow{2}{*}{6,0} & Média & 3.07 & 3.00 & 3.55 & 3.27 & 3.34 & 3.81 \\
\hline & & Desvio Padrão & 0.05 & 0.07 & 0.28 & 0.11 & 0.18 & 0.20 \\
\hline \multirow{6}{*}{ CAP 40} & \multirow{2}{*}{5,0} & Média & 4.80 & 4.74 & 5.61 & 5.52 & 6.43 & 6.32 \\
\hline & & Desvio Padrão & 0.18 & 0.16 & 0.19 & 0.12 & 0.10 & 0.26 \\
\hline & \multirow{2}{*}{5,5} & Média & 3.99 & 3.84 & 4.26 & 4.20 & 4.22 & 4.33 \\
\hline & & Desvio Padrão & 0.18 & 0.04 & 0.09 & 0.05 & 0.29 & 0.18 \\
\hline & \multirow{2}{*}{6,0} & Média & 3.00 & 3.03 & 3.84 & 3.77 & 3.75 & 3.66 \\
\hline & & Desvio Padrão & 0.02 & 0.08 & 0.09 & 0.05 & 0.12 & 0.11 \\
\hline
\end{tabular}

As Figuras 4.6, 4.7 e 4.8 apresentam as variações dos volumes de vazios dos corpos-de-prova em função do tipo e teor de asfalto e da presença ou não de cal na moldagem, para os agregados basalto, granito e gabro, respectivamente.

Basalto

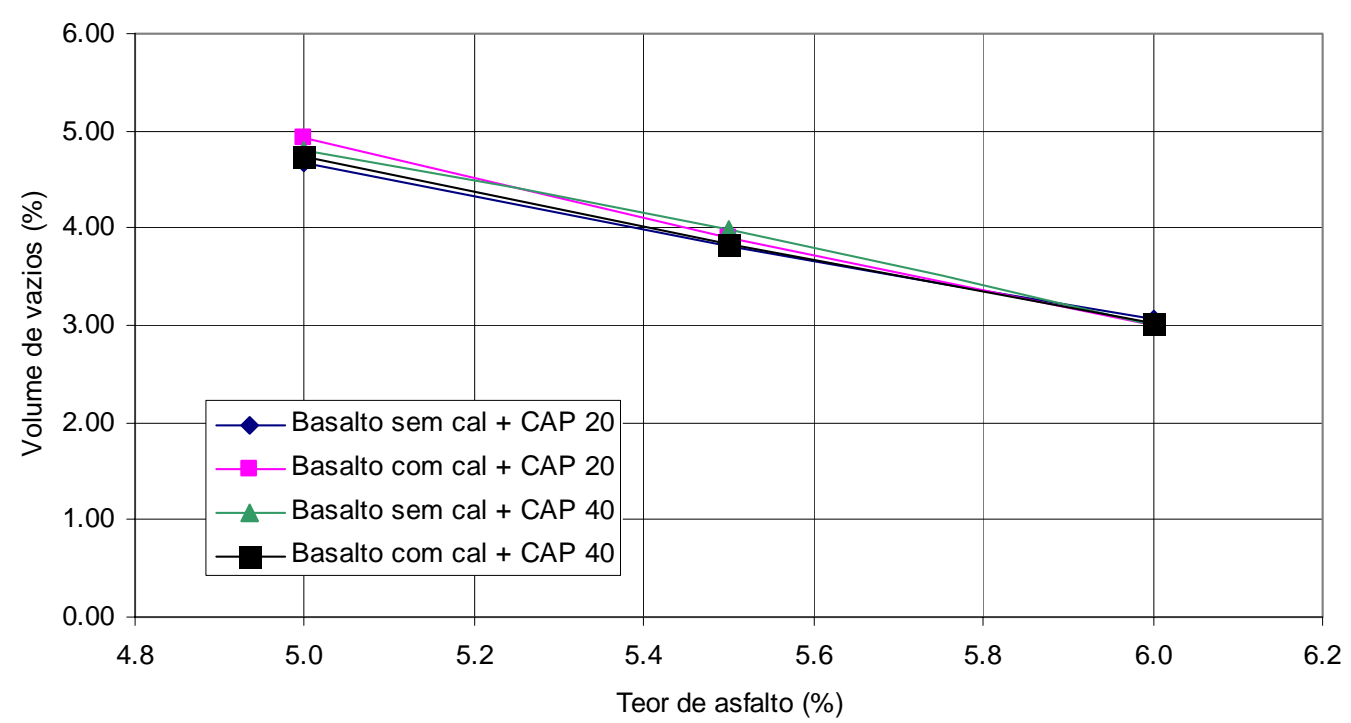

Figura 4.6: Volumes de vazios em função do teor e tipo de asfalto e presença de cal para o agregado tipo basalto. 


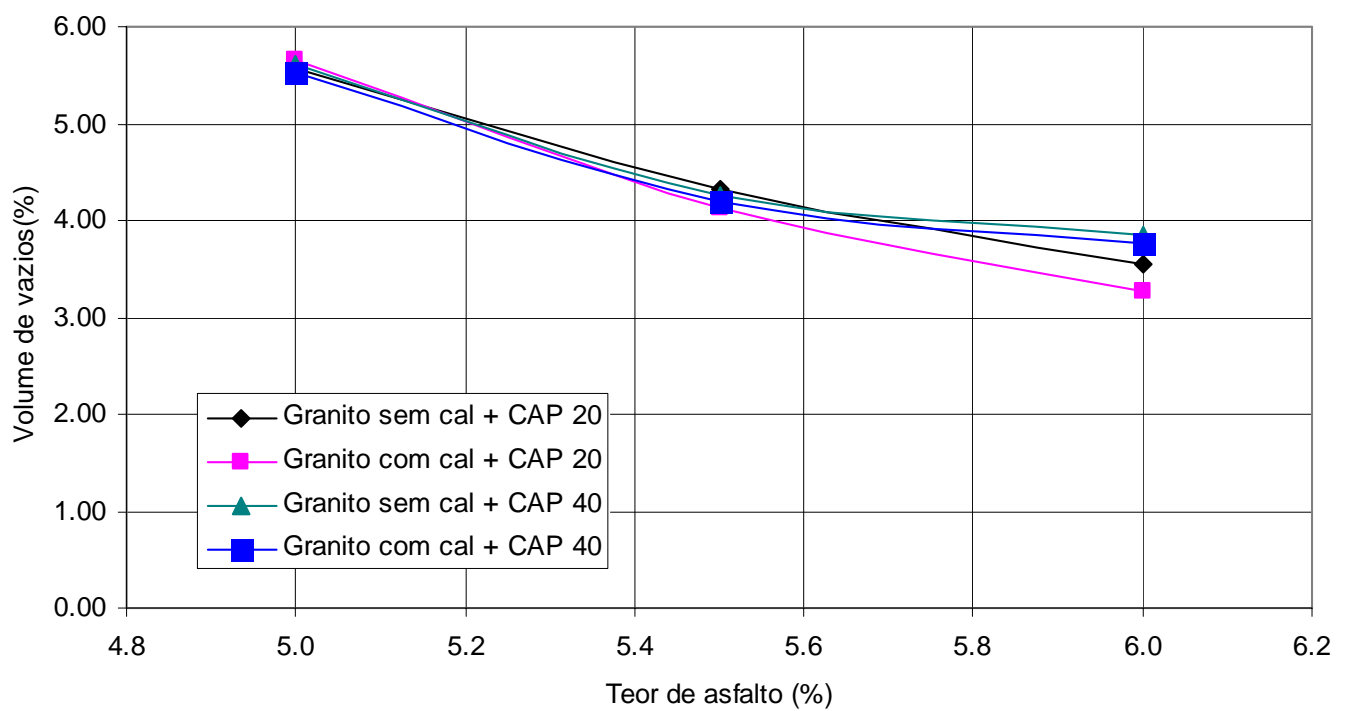

Figura 4.7: Volumes de vazios em função do teor e tipo de asfalto e presença de cal para o agregado tipo granito.

Gabro

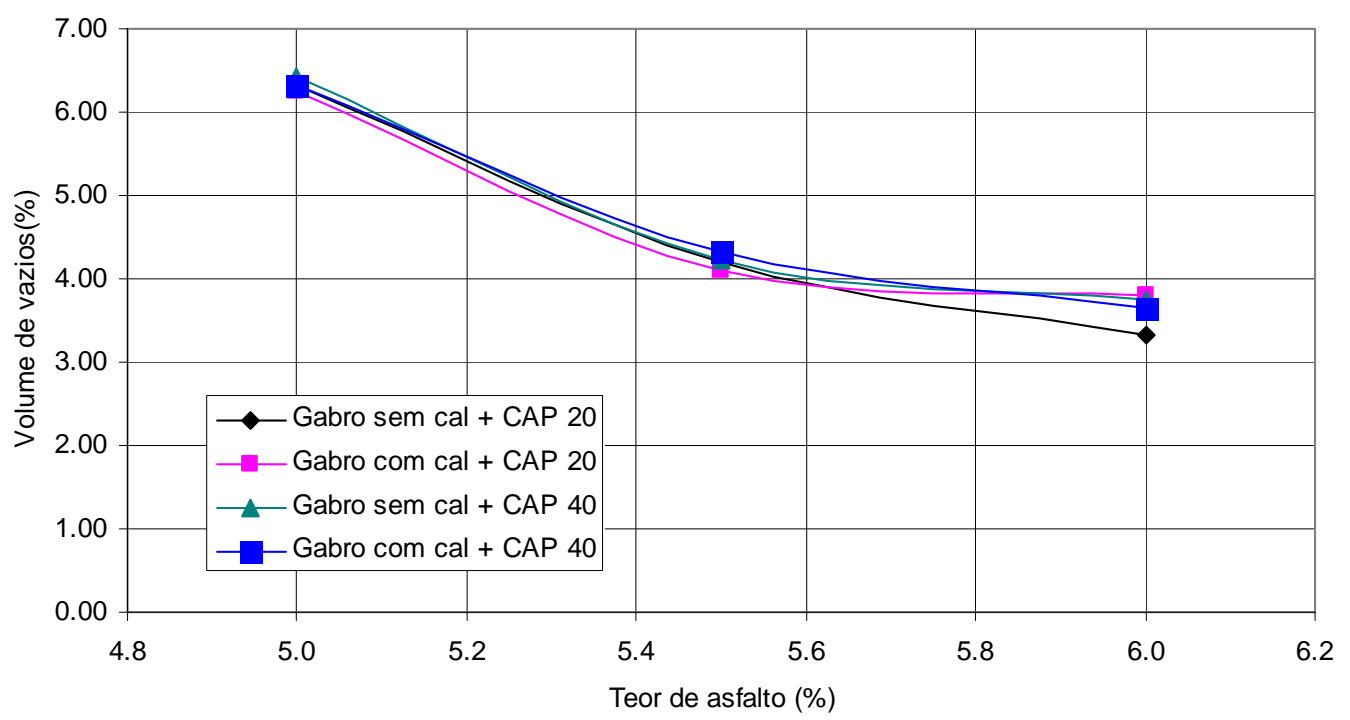

Figura 4.8: Volumes de vazios em função do teor e tipo de asfalto e presença de cal para o agregado tipo gabro. 


\subsubsection{Resistências à tração}

Na Tabela 4.4 são apresentadas as resistências à tração médias dos corpos-de-prova utilizados no Programa II. Observando-se os resultados apresentados nessa tabela nota-se que, de uma maneira geral, os desvios-padrão não são muito grandes em relação aos valores das médias, indicando boa reprodução dos resultados dos ensaios. Observa-se também que os corpos-deprova produzidos com CAP 40 apresentam, para todos os teores de asfalto, sem exceção, valores maiores de resistência à tração que os produzidos com CAP 20, independente do agregado analisado.

Tabela 4.4: Resistências à tração médias e desvios-padrão dos corpos-de-prova utilizados no Programa II.

\begin{tabular}{|c|c|c|c|c|c|c|c|c|}
\hline & & & \multicolumn{2}{|c|}{ Basalto } & \multicolumn{2}{|c|}{ Granito } & \multicolumn{2}{|c|}{ Gabro } \\
\hline & \multicolumn{2}{|c|}{ Teor de Asfalto } & sem cal & com cal & sem cal & com cal & sem cal & com cal \\
\hline \multirow{6}{*}{ CAP 20} & \multirow{2}{*}{5,0} & Média & 1,90 & 1,86 & 1,70 & 1,64 & 1,55 & 1,66 \\
\hline & & Desvio Padrão & 0,01 & 0,21 & 0,08 & 0,02 & 0,04 & 0,05 \\
\hline & \multirow{2}{*}{5,5} & Média & 1,62 & 1,68 & 1,71 & 1,64 & 1,90 & 2,11 \\
\hline & & Desvio Padrão & 0,07 & 0,17 & 0,05 & 0,08 & 0,04 & 0,04 \\
\hline & \multirow{2}{*}{6,0} & Média & 1,62 & 1,49 & 1,70 & 1,61 & 1,73 & 1,74 \\
\hline & & Desvio Padrão & 0,09 & 0,06 & 0,03 & 0,06 & 0,05 & 0,04 \\
\hline \multirow{6}{*}{ CAP 40} & \multirow{2}{*}{5,0} & Média & 2,49 & 2,81 & 2,31 & 2,36 & 2,31 & 1,99 \\
\hline & & Desvio Padrão & 0,19 & 0,17 & 0,02 & 0,09 & 0,13 & 0,20 \\
\hline & \multirow{2}{*}{5,5} & Média & 2,82 & 2,89 & 2,49 & 2,36 & 2,50 & 2,02 \\
\hline & & Desvio Padrão & 0,05 & 0,04 & 0,14 & 0,07 & 0,13 & 0,27 \\
\hline & \multirow[b]{2}{*}{6,0} & Média & 2,58 & 2,42 & 2,77 & 2,58 & 2,52 & 2,15 \\
\hline & & Desvio Padrão & 0,08 & 0,03 & 0,04 & 0,05 & 0,11 & 0,12 \\
\hline
\end{tabular}

Nas Figuras 4.9, 4.10 e 4.11 são apresentadas as variações das resistências à tração para os agregados basalto, granito e gabro, respectivamente, para os asfaltos utilizados e a presença ou não de cal, em função do teor de asfalto (à esquerda) e volume de vazios (à direita). Observando-se essas figuras nota-se que não há um padrão claramente definido para a variação da resistência à tração, tanto em função do teor de asfalto, como do volume de vazios, pois para algumas condições as curvas apresentam máximos e, em outras, são crescentes ou decrescentes. 

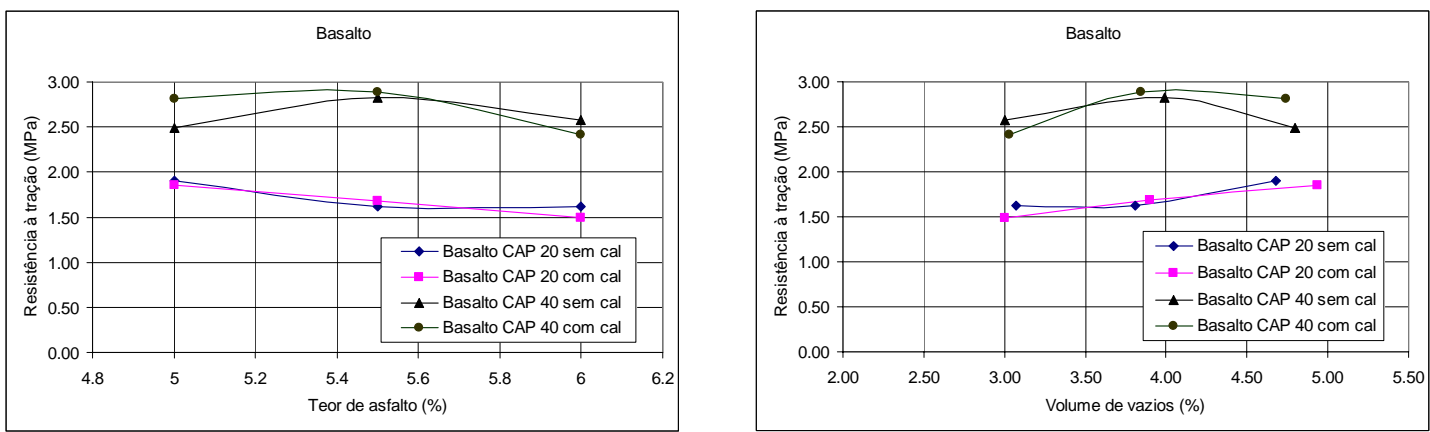

Figura 4.9: Variação da resistência à tração em função do teor de asfalto ou do volume de vazios para o agregado basalto.
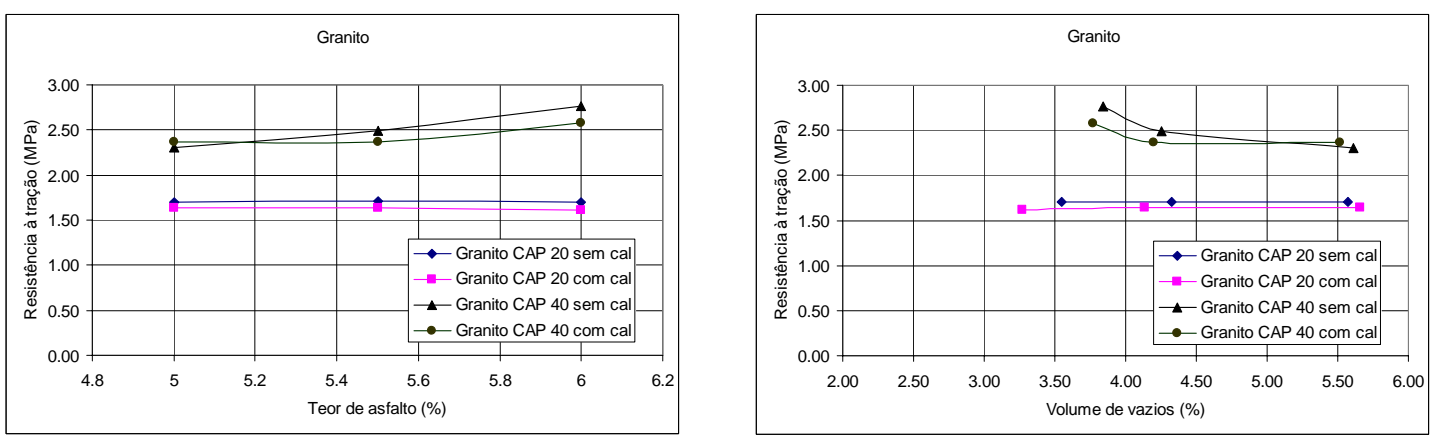

Figura 4.10: Variação da resistência à tração em função do teor de asfalto ou do volume de vazios para o agregado granito.
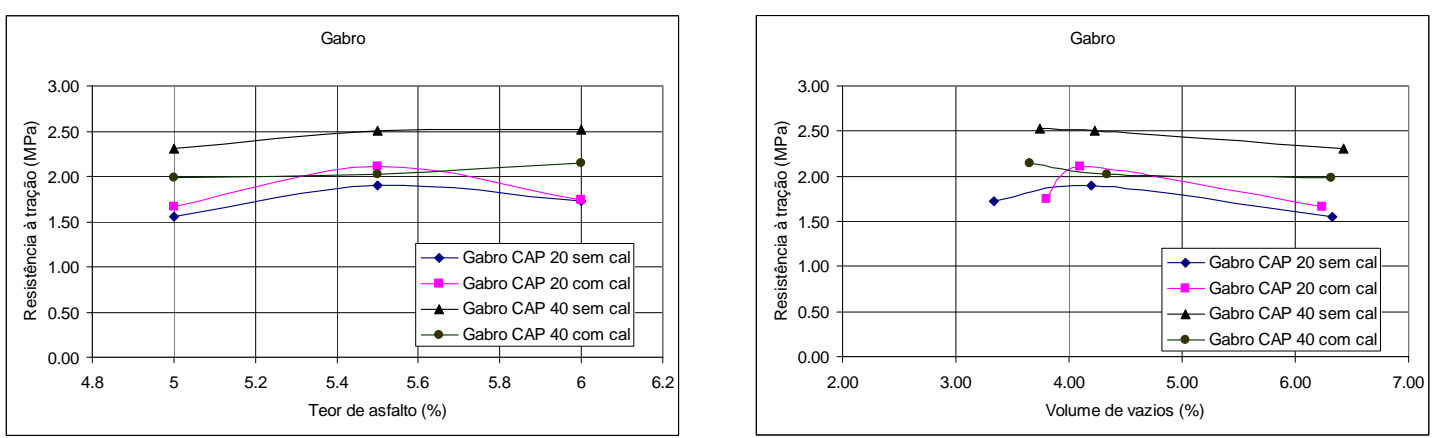

Figura 4.11: Variação da resistência à tração em função do teor de asfalto ou do volume de vazios para o agregado gabro.

\subsubsection{Módulos de resiliência}

Na Tabela 4.5 são apresentados, a título de exemplo, os valores médios dos módulos de resiliência totais (calculados segundo a AASHTO) dos corpos-de-prova utilizados no 
Programa II, em função da temperatura de ensaio, do agregado, da presença ou não de cal, do tipo e do teor de asfalto utilizados. No Apêndice II podem ser encontrados os valores de módulos de resiliência totais e instantâneos calculados segundo os procedimentos da AASHTO e do NCHRP.

Observando-se os resultados apresentados nessa Tabela (4.5) nota-se que, de uma maneira geral, os módulos de resiliência crescem com o decréscimo da temperatura e com o decréscimo do teor de asfalto, como era esperado. Observa-se também que os corpos-deprova produzidos com CAP 40 apresentam, para todos os teores de asfalto, sem exceção, valores maiores de módulo de resiliência que os produzidos com CAP 20, independente do agregado analisado, quando comparados em mesmas temperaturas.

Tabela 4.5: Módulos de resiliência totais (AASHTO) médios dos corpos-de-prova utilizados no Programa II.

\begin{tabular}{|c|c|c|c|c|c|c|c|c|}
\hline & \multirow{3}{*}{ Temperatura } & \multirow{3}{*}{ Teor } & \multirow{2}{*}{\multicolumn{2}{|c|}{ Basalto }} & & & & \\
\hline & & & & & \multicolumn{2}{|c|}{ Gabro } & \multicolumn{2}{|c|}{ Granito } \\
\hline & & & sem cal & com cal & sem cal & com cal & sem cal & com cal \\
\hline \multirow{9}{*}{ CAP 20} & \multirow{3}{*}{10} & 5,0 & 27298 & 32578 & 18938 & 23653 & 18394 & 18635 \\
\hline & & 5,5 & 21256 & 27873 & 27269 & 23777 & 15612 & 20876 \\
\hline & & 6,0 & 16877 & 18489 & 22029 & 24065 & 16887 & 21733 \\
\hline & \multirow{3}{*}{25} & 5,0 & 7856 & 7461 & 7710 & 8143 & 7403 & 8254 \\
\hline & & 5,5 & 6252 & 6911 & 9431 & 8160 & 7093 & 7237 \\
\hline & & 6,0 & 5711 & 4786 & 5757 & 6024 & 7379 & 7259 \\
\hline & \multirow{3}{*}{40} & 5,0 & 3080 & 3397 & 2985 & 2467 & 2736 & 3314 \\
\hline & & 5,5 & 1791 & 2471 & 2728 & 4325 & 2754 & 3456 \\
\hline & & 6,0 & 1615 & 1884 & 1705 & 2216 & 2185 & 2514 \\
\hline \multirow{9}{*}{ CAP 40} & \multirow{3}{*}{10} & 5,0 & 37013 & 42235 & 33065 & 36924 & 32259 & 37327 \\
\hline & & 5,5 & 28721 & 26887 & 24098 & 26943 & 28799 & 29178 \\
\hline & & 6,0 & 19436 & 22162 & 22522 & 25887 & 24463 & 40869 \\
\hline & \multirow{3}{*}{25} & 5,0 & 15915 & 14652 & 11268 & 13210 & 13235 & 15255 \\
\hline & & 5,5 & 10871 & 13516 & 12915 & 12662 & 12088 & 10746 \\
\hline & & 6,0 & 10943 & 7886 & 12190 & 11829 & 12613 & 12374 \\
\hline & \multirow{3}{*}{40} & 5,0 & 6450 & 6428 & 5427 & 6892 & 5160 & 5671 \\
\hline & & 5,5 & 4503 & 5134 & 6268 & 6426 & 5660 & 5826 \\
\hline & & 6,0 & 3959 & 3164 & 5801 & 4473 & 5987 & 7049 \\
\hline
\end{tabular}

A seguir são apresentadas as Figuras 4.12, 4.13 e 4.14 que representam as variações dos valores dos módulos de resiliência para os agregados basalto, granito e gabro, 
respectivamente, em função do tipo e teor de asfalto, presença de cal e temperatura de ensaio. Cada figura é composta de quatro gráficos dispostos aos pares, lado a lado, para permitir comparações acerca da influência do tipo de asfalto e/ou da presença de cal.

Observando-se a Figura 4.12, que apresenta os valores dos módulos de resiliência para as misturas com o agregado basalto, nota-se que as misturas com CAP 40 sempre apresentaram valores de módulos maiores que as com CAP 20, quando comparadas para mesmas temperaturas de ensaio e mesmos teores de asfalto. Nota-se também que, para esses agregados, as misturas com cal apresentaram valores maiores de módulo em relação às sem cal somente para as baixas temperaturas de ensaio $\left(10^{\circ} \mathrm{C}\right)$. Para as outras temperaturas de ensaio não há um comportamento bem definido.
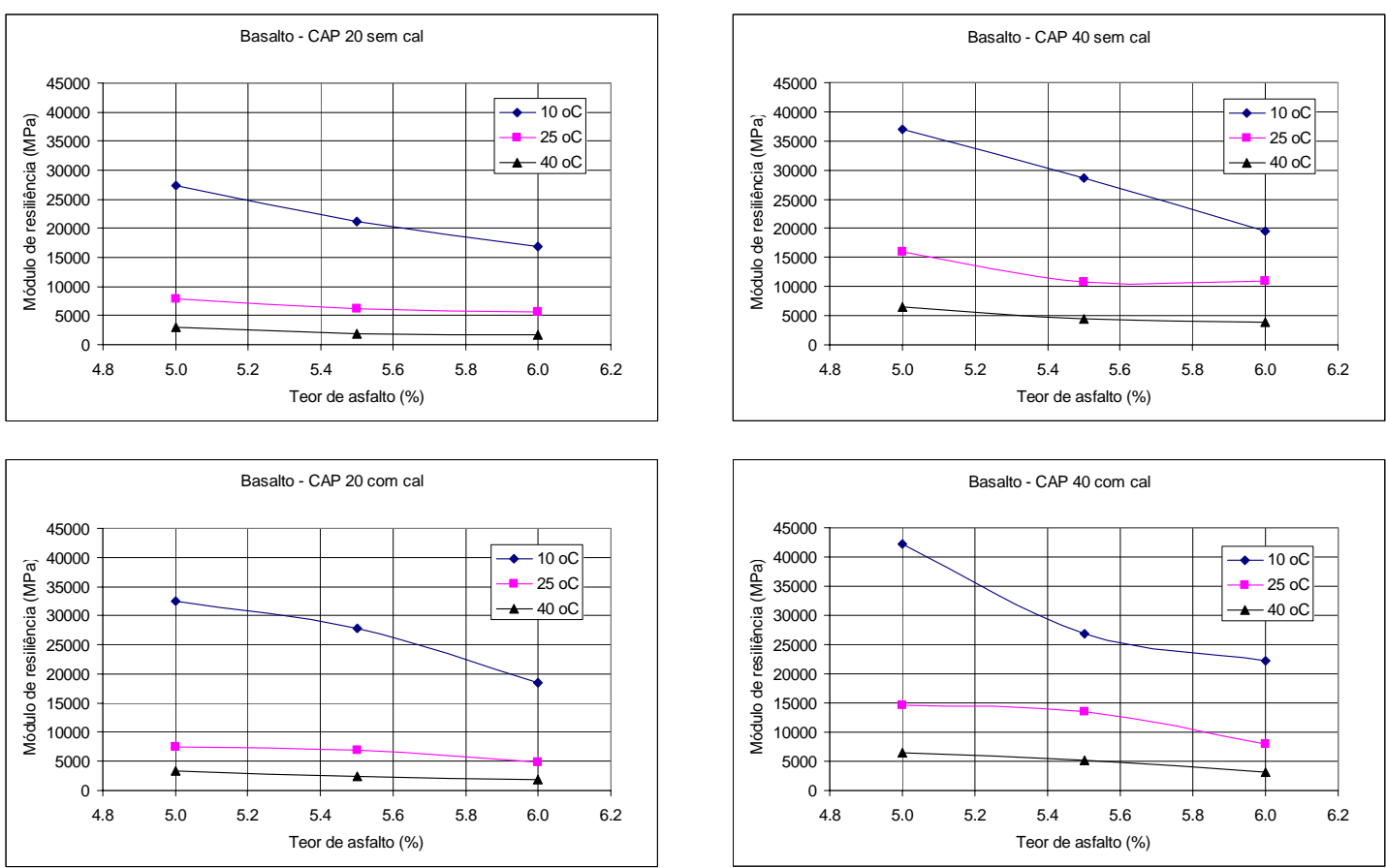

Figura 4.12: Variação do módulo de resiliência em função do teor de asfalto para os diferentes tipos de asfaltos e temperaturas de ensaio para o agregado basalto. 
A Figura 4.13 apresenta os valores dos módulos de resiliência para as misturas com o agregado granito. Nela percebe-se que os comportamentos das curvas, de uma maneira geral, assemelham-se aos da Figura anterior (basalto), com exceção de algumas combinações de temperatura e tipo de asfalto, onde há curvas que apresentam pontos de mínimo bem caracterizados.

A Figura 4.14 apresenta os valores dos módulos de resiliência para as misturas com o agregado gabro. Observando-se a Figura 4.14 pode-se notar que os comportamentos das curvas também são, de uma maneira geral, semelhantes aos da Figura 4.12 (basalto), com exceção de algumas combinações de temperatura e tipo de asfalto, que, nesses casos, apresentam pontos de máximo bem caracterizados.
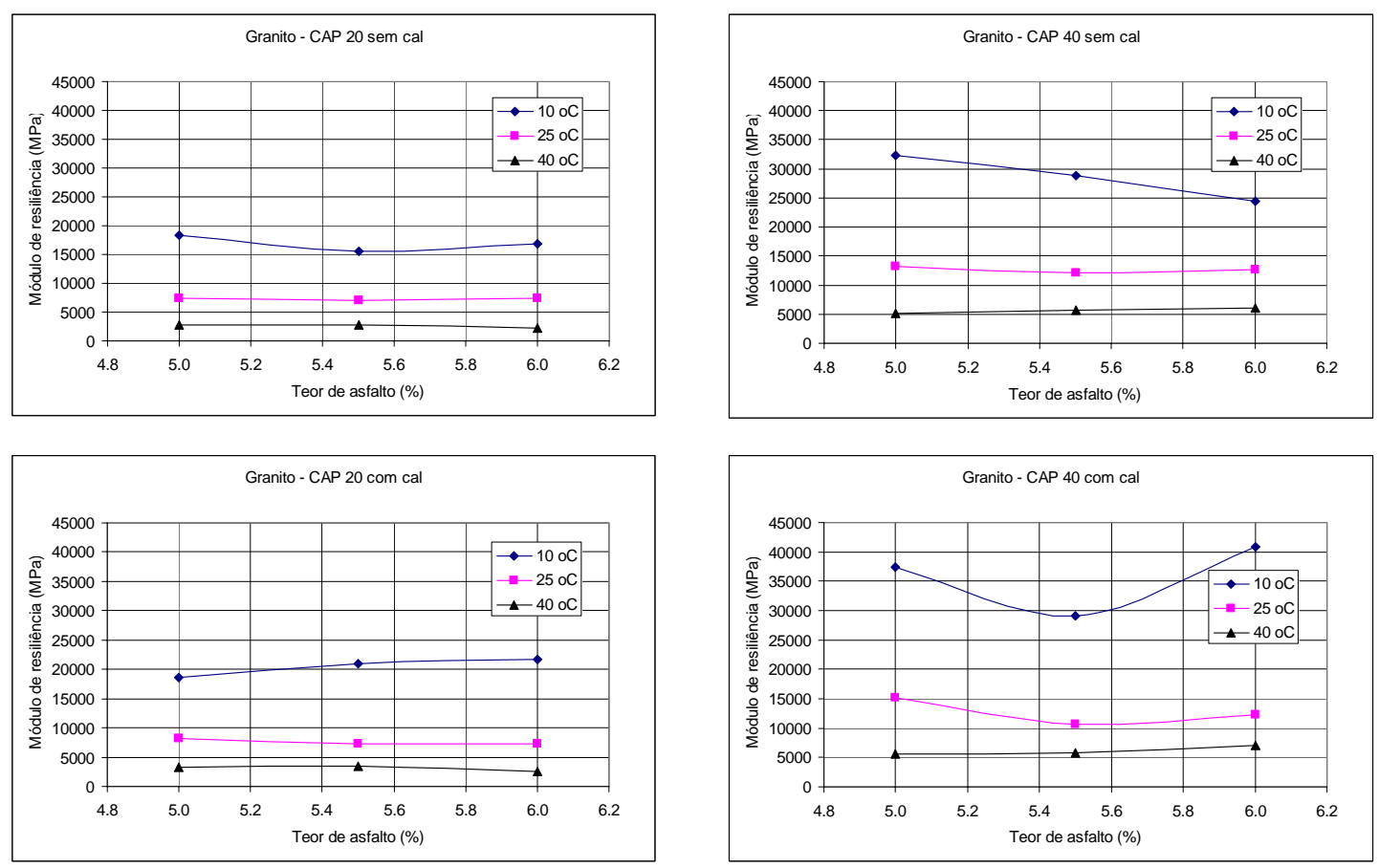

Figura 4.13: Variação do módulo de resiliência em função do teor de asfalto para os diferentes tipos de asfaltos e temperaturas de ensaio para o agregado granito. 

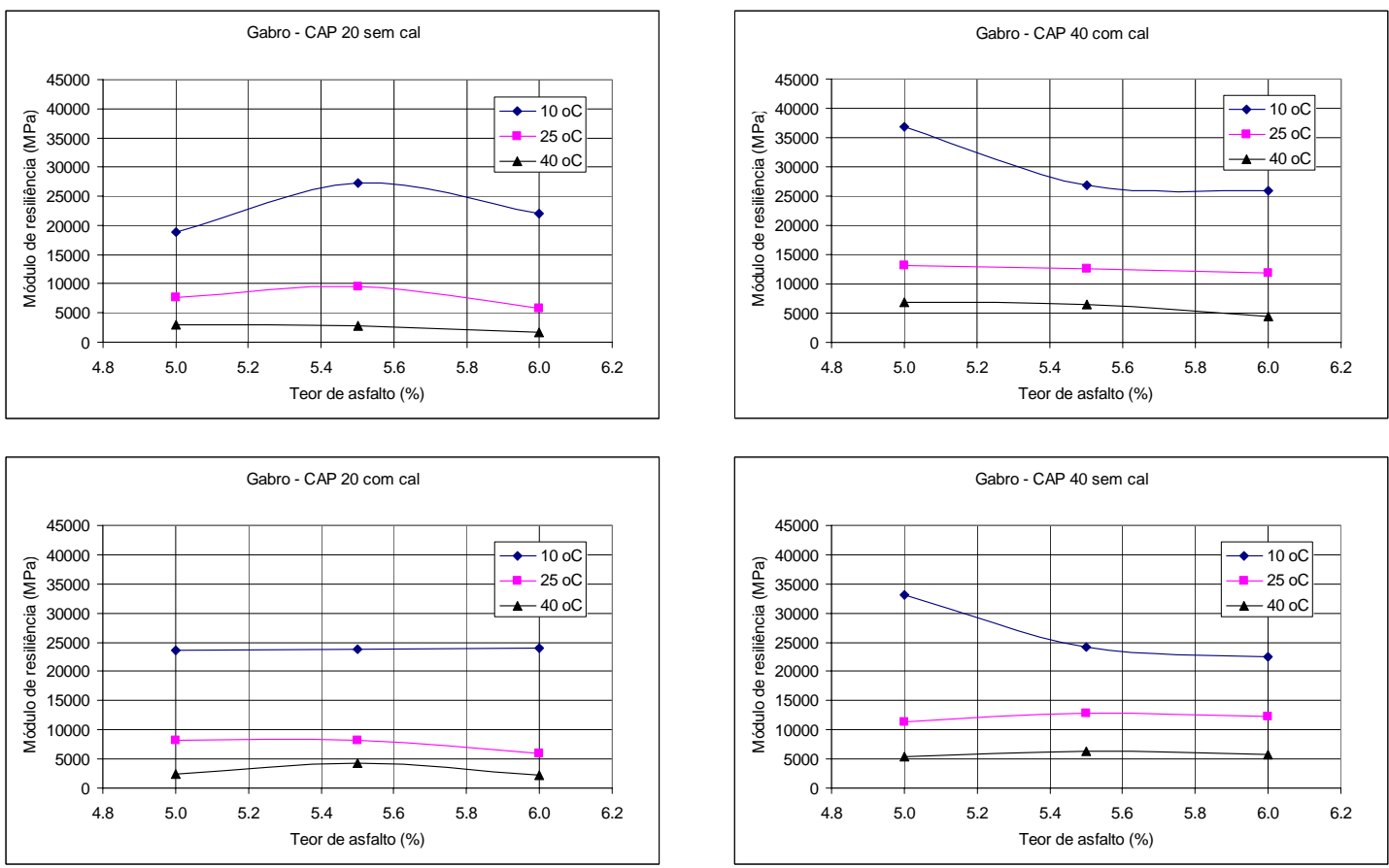

Figura 4.14: Variação do módulo de resiliência em função do teor de asfalto para os diferentes tipos de asfaltos e temperaturas de ensaio para o agregado gabro.

Nas Figuras 4.15, 4.16 e 4.17 são apresentadas as variações dos valores dos módulos de resiliência em função da temperatura de ensaio, para os agregados basalto, granito e gabro, respectivamente. Observando-se essas figuras nota-se que o efeito da cal nos valores dos módulos de resiliência é, de uma maneira geral, mais notável para as baixas temperaturas de ensaio, principalmente para os baixos teores de asfalto, ou seja, aparentemente a cal atua como enrijecedor quando os teores de asfalto são baixos, talvez pelo aumento da superfície específica da mistura e conseqüente redução da película de asfalto. Para as outras temperaturas de ensaio testadas a cal aparentemente não exerce efeito significativo nos valores dos módulos de resiliência, independentemente do teor de asfalto utilizado. 

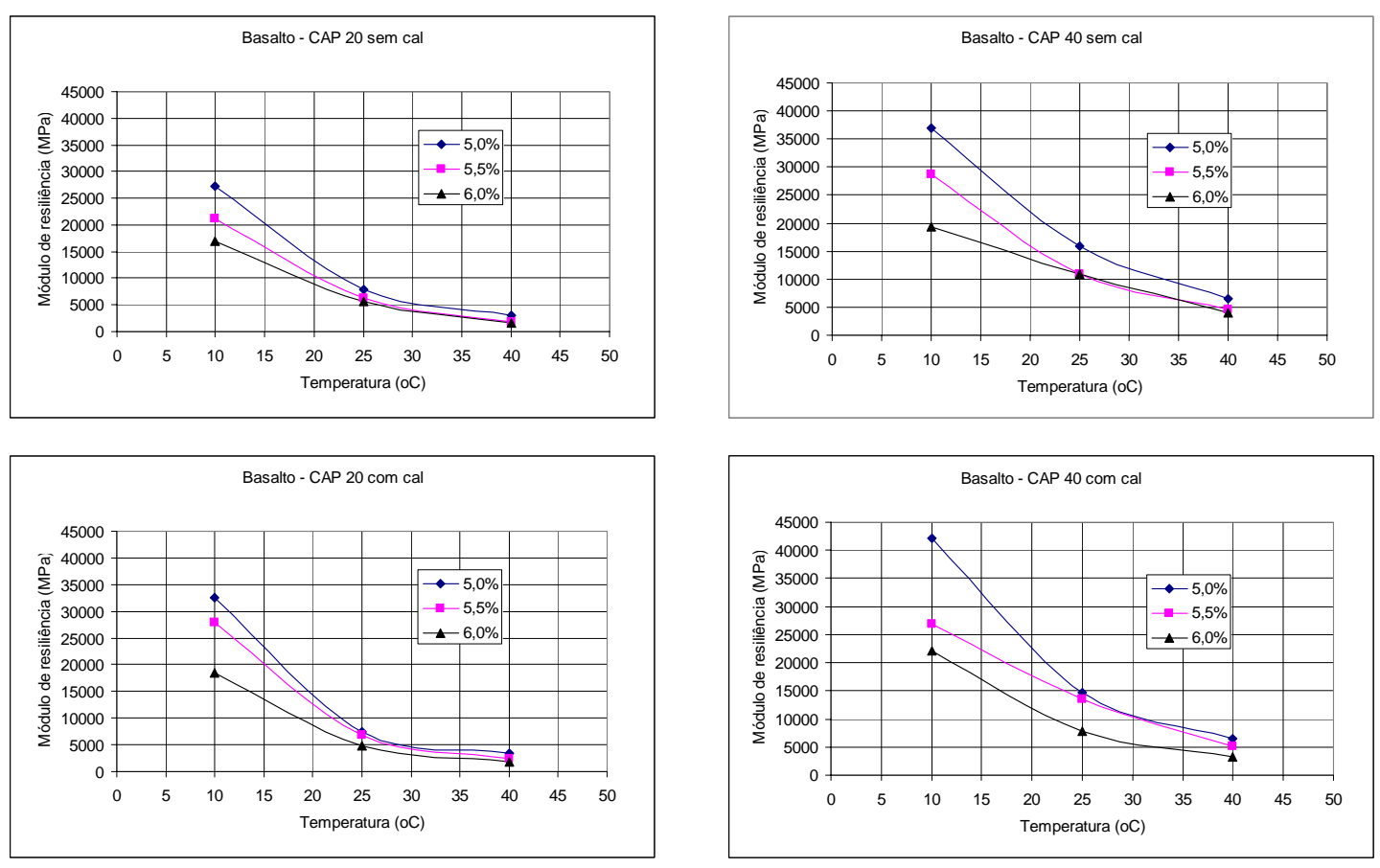

Figura 4.15: Variação do módulo de resiliência em função da temperatura de ensaio para os diferentes tipos e teores de asfalto para o agregado basalto.
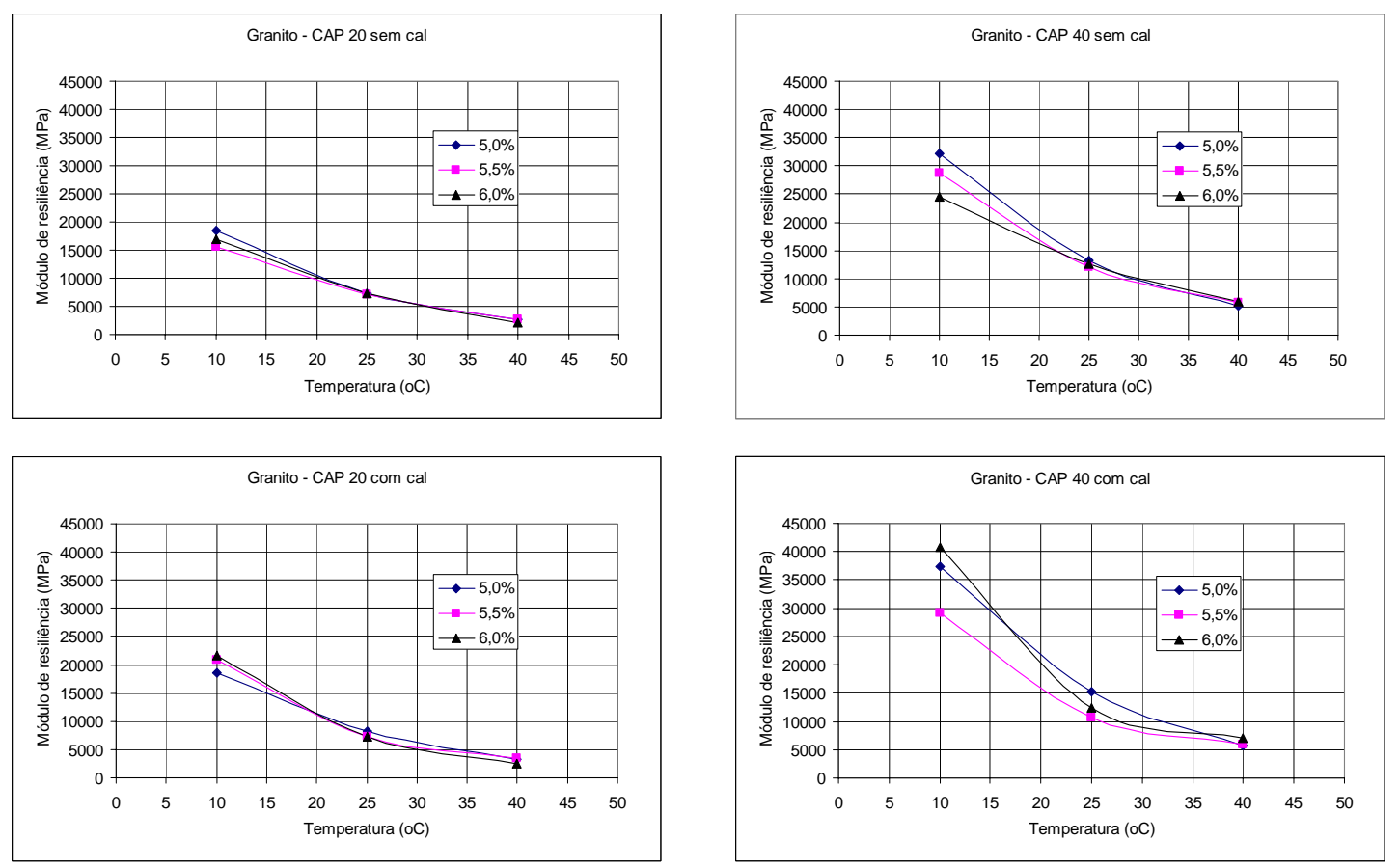

Figura 4.16: Variação do módulo de resiliência em função da temperatura de ensaio para os diferentes tipos e teores de asfalto para o agregado granito. 

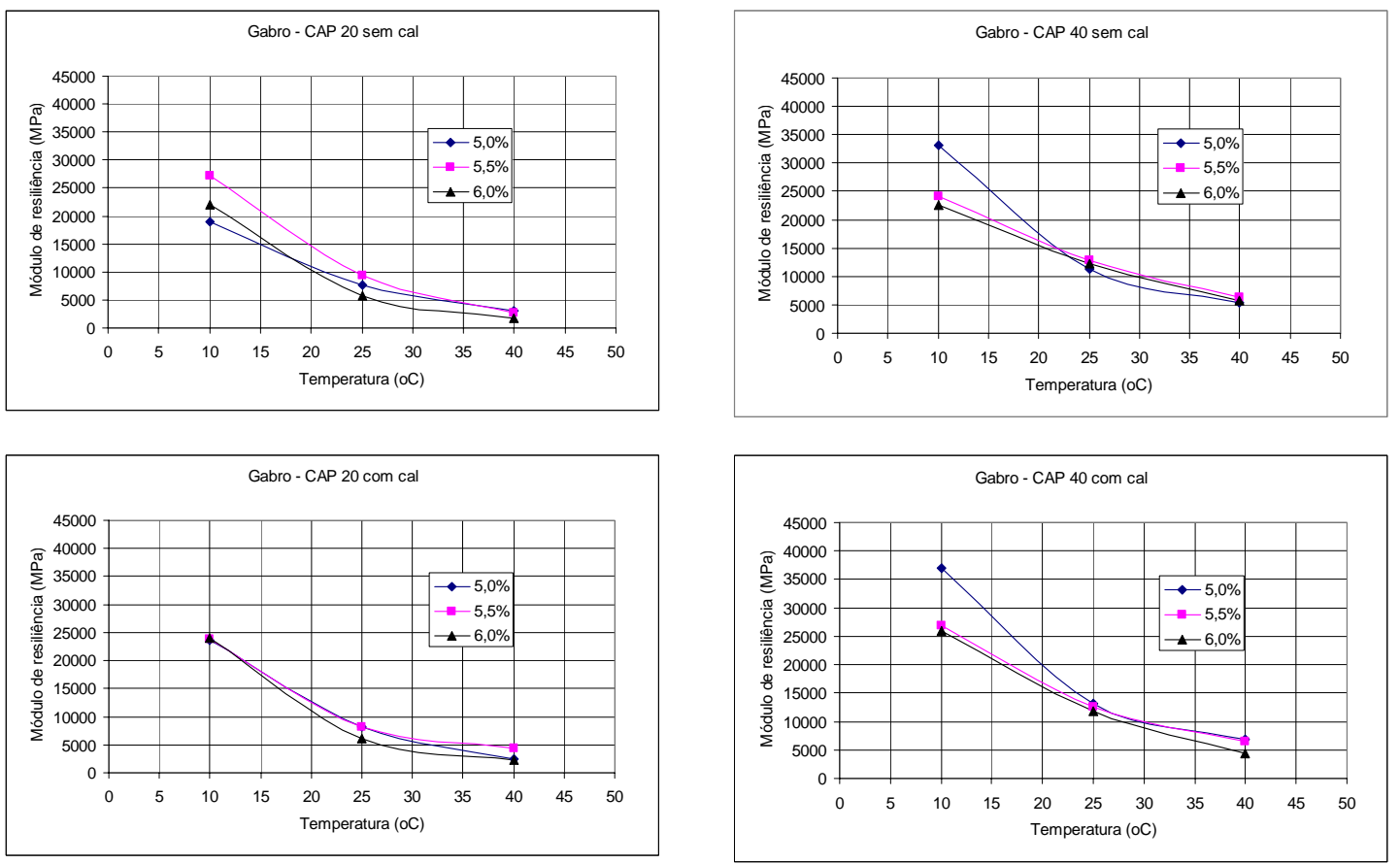

Figura 4.17: Variação do módulo de resiliência em função da temperatura de ensaio para os diferentes tipos e teores de asfalto para o agregado gabro.

\subsubsection{Relações módulo de resiliência / resistência à tração - MR / RT}

Na Tabela 4.6 são apresentados, a título de exemplo, os valores médios das relações dos módulos de resiliência totais (calculados segundo a AASHTO) pelas respectivas resistências á tração, a $25^{\circ} \mathrm{C}$, dos corpos-de-prova utilizados no Programa II, em função do agregado, da presença ou não de cal, do tipo e do teor de asfalto utilizados. No Apêndice III podem ser encontrados os valores das outras relações entre os módulos de resiliência totais e instantâneos, calculados segundo os procedimentos da AASHTO e do NCHRP, e as resistências à tração. 
Tabela 4.6: Valores médios e desvios-padrão das relações entre os módulos de resiliência totais (AASHTO) e as resistências à tração dos corpos-de-prova utilizados no Programa II.

\begin{tabular}{|c|c|c|c|c|c|c|c|c|}
\hline & & & \multicolumn{2}{|c|}{ Basalto } & \multicolumn{2}{|c|}{ Granito } & \multicolumn{2}{|c|}{ Gabro } \\
\hline & \multicolumn{2}{|c|}{ Teor de Asfalto } & sem cal & com cal & sem cal & com cal & sem cal & com cal \\
\hline \multirow{6}{*}{ CAP 20} & \multirow{2}{*}{5,0} & Média & 4132 & 4000 & 4258 & 5035 & 5034 & 4919 \\
\hline & & Desvio Padrão & 496 & 280 & 129 & 308 & 66 & 1284 \\
\hline & \multirow{2}{*}{5,5} & Média & 3848 & 4127 & 4156 & 4398 & 4921 & 3864 \\
\hline & & Desvio Padrão & 232 & 383 & 298 & 505 & 43 & 423 \\
\hline & \multirow{2}{*}{6,0} & Média & 3504 & 3215 & 4336 & 4494 & 3327 & 3447 \\
\hline & & Desvio Padrão & 612 & 250 & 312 & 478 & 228 & 588 \\
\hline \multirow{6}{*}{ CAP 40} & \multirow{2}{*}{5,0} & Média & 6472 & 5186 & 5746 & 6486 & 4893 & 6644 \\
\hline & & Desvio Padrão & 1566 & 707 & 308 & 1194 & 477 & 739 \\
\hline & \multirow{2}{*}{5,5} & Média & 3853 & 4672 & 4833 & 4513 & 5173 & 6303 \\
\hline & & Desvio Padrão & 474 & 1127 & 618 & 129 & 747 & 759 \\
\hline & \multirow{2}{*}{6,0} & Média & 4236 & 3280 & 4555 & 4801 & 4937 & 5495 \\
\hline & & Desvio Padrão & 555 & 29 & 577 & 347 & 211 & 362 \\
\hline
\end{tabular}

A seguir são apresentadas as Figuras 4.18, 4.19 e 4.20 que representam as variações dos valores das relações entre os módulos de resiliência totais (AASHTO) e as resistências à tração, para a temperatura de $25^{\circ} \mathrm{C}$, para os agregados basalto, granito e gabro, respectivamente, em função do tipo e teor de asfalto ou volume de vazios e a presença de cal. Cada figura é composta de dois gráficos dispostos lado a lado, para permitir comparações acerca da influência da representação das curvas das relações MR /RT em função do teor de asfalto ou do volume de vazios das misturas.
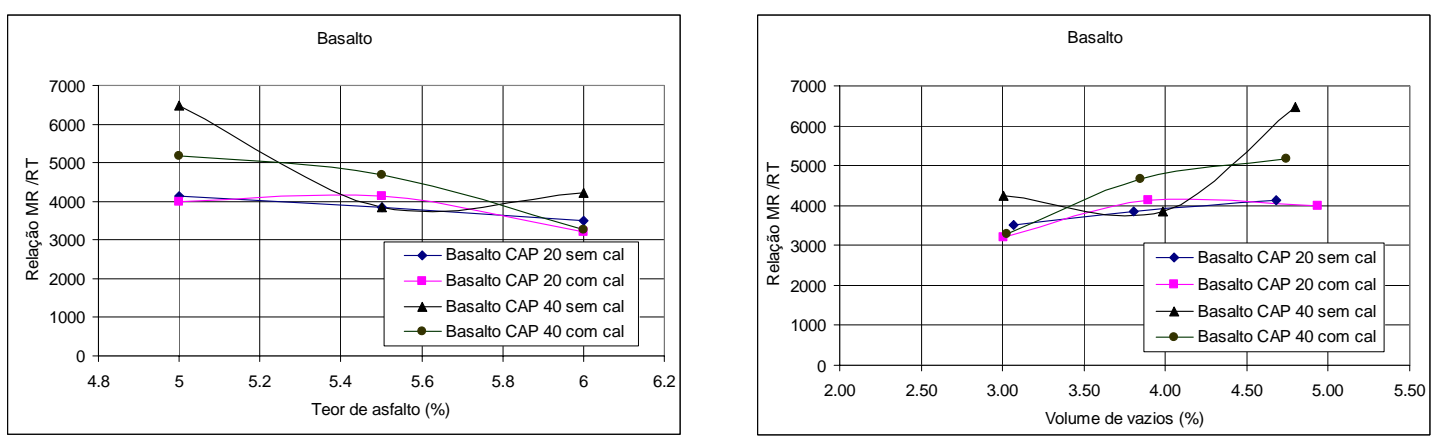

Figura 4.18: Variação das relações entre os módulos de resiliência total (AASHTO) e as resistências à tração em função do tipo e teor de asfalto ou volume de vazios para o agregado basalto. 
Observando-se a Figura 4.18 nota-se que, de uma maneira geral, as relações MR /RT são decrescentes com o teor de asfalto contido na mistura, ou crescentes com o volume de vazios. Com exceção da mistura basalto com CAP 40 e cal, todas se apresentaram da mesma maneira, com tendência de estabilização para teores de asfalto baixos ou volumes de vazios altos.

Na Figura 4.19, que apresenta as relações MR /RT para o agregado granito, percebe-se que os comportamentos das curvas, de uma maneira geral, se assemelham, são decrescentes com o teor de asfalto e crescentes com o volume de vazios, e apresentam tendências de estabilização para altos teores de asfalto ou baixos volumes de vazios, porém de forma contrária à observada na Figura 4.18, já que as curvas apresentam concavidades contrárias.
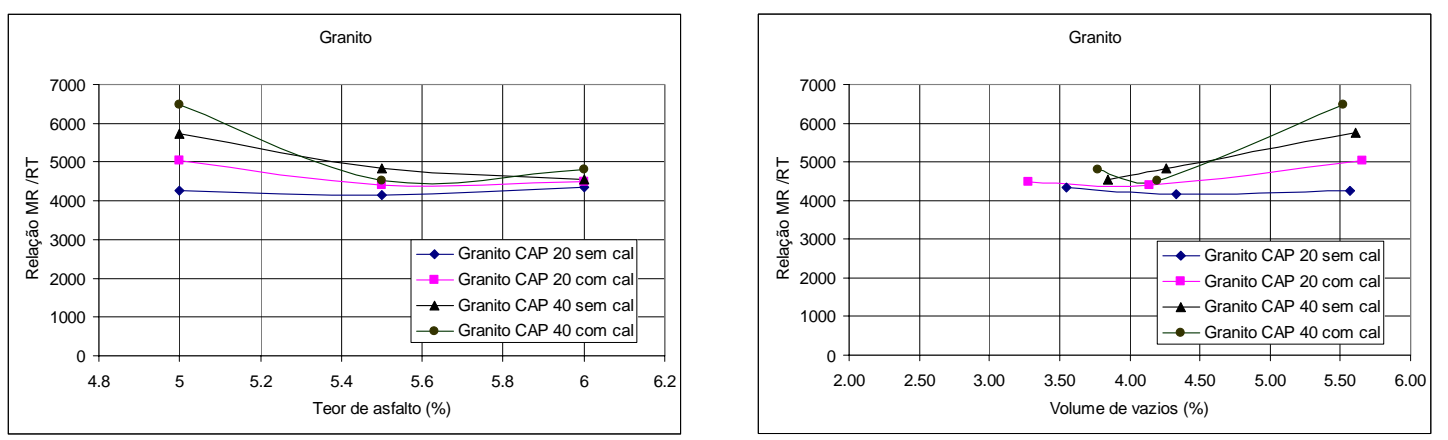

Figura 4.19: Variação das relações entre os módulos de resiliência total (AASHTO) e as resistências à tração em função do tipo e teor de asfalto ou volume de vazios para o agregado granito

A Figura 4.20 apresenta os valores das relações MR /RT para o agregado gabro. Observandose essa figura nota-se que também há tendência de estabilização dos valores das relações MR/RT que, nesse caso, se dá para baixos teores de asfalto ou altos volumes de vazios e os comportamentos das curvas são semelhantes aos da Figura 4.18 (basalto). 

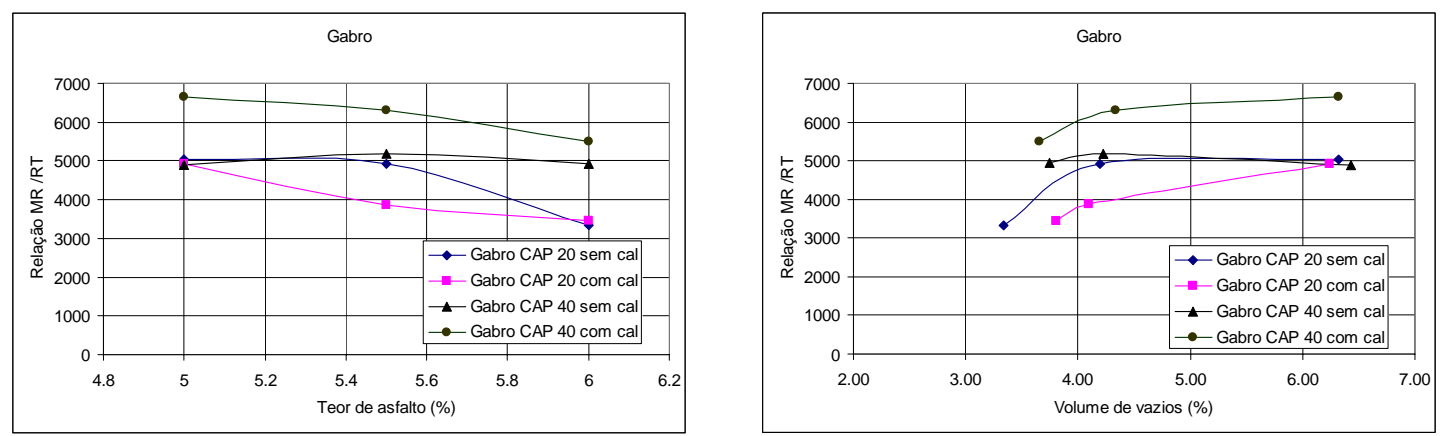

Figura 4.20: Variação das relações entre os módulos de resiliência total (AASHTO) e as resistências à tração em função do tipo e teor de asfalto ou volume de vazios para o agregado gabro.

Quanto aos valores absolutos das relações $\mathrm{MR} / \mathrm{RT}$, o que chama a atenção é a pequena incidência de valores dessa relação próximos a 3.000, considerado como valores de referência para misturas que apresentam boa resistência à fadiga. $\mathrm{O}$ que se pode perceber é que para o "teor de asfalto de trabalho" (5,5\%), os valores estão entre 4.000 e 5.000 para a maioria das combinações das variáveis estudadas, e que os valores decrescem para teores maiores de asfalto e crescem para teores menores, ultrapassando, em alguns casos, mais de 6.000.

\subsubsection{Relações entre módulos de resiliência totais e instantâneos}

Os módulos de resiliência foram determinados por dois procedimentos, segundo a AASHTO TP-31 e segundo a NCHRP Project 1-28, como já descrito anteriormente. Em ambos os casos foram calculados tanto os módulos totais como os instantâneos. A seguir são apresentadas as relações entre os módulos totais pelas duas normas, além de suas relações com os módulos instantâneos, uma vez que nesse trabalho restringiu-se a apresentação aos valores dos módulos totais obtidos segundo o procedimento da AASHTO. 
A Figura 4.21 apresenta as relações entre os módulos de resiliência totais (à esquerda) e instantâneos (à direita), determinados segundo os dois procedimentos já citados, obtidos para todas as condições experimentais, ou seja, nas três temperaturas, com e sem cal, para os dois asfaltos e os três agregados. Nela nota-se que há uma boa correspondência entre os módulos obtidos pelos dois procedimentos, tanto para os totais como para os instantâneos, com melhor coeficiente de correlação para os módulos totais.
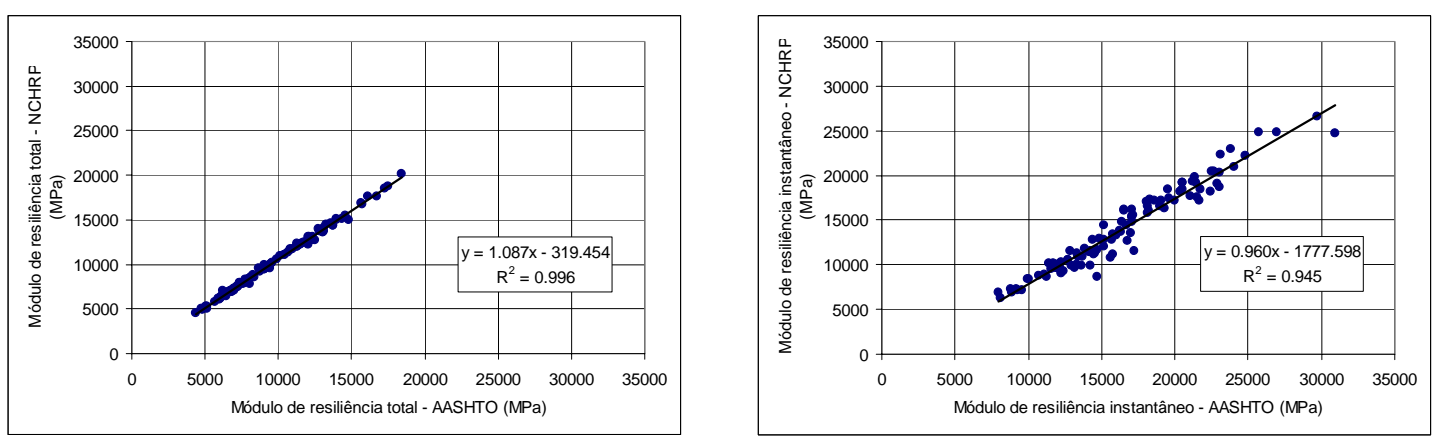

Figura 4.21: Relações entre os módulos de resiliência totais (esquerda) e instantâneos (direita) determinados segundo os procedimentos da AASHTO e do NCHRP, para todas as condições do experimento.

A Figura 4.22 apresenta as relações entre os módulos de resiliência totais e instantâneos, para o procedimento da AASHTO (à esquerda) e para o procedimento do NCHRP (à direita).
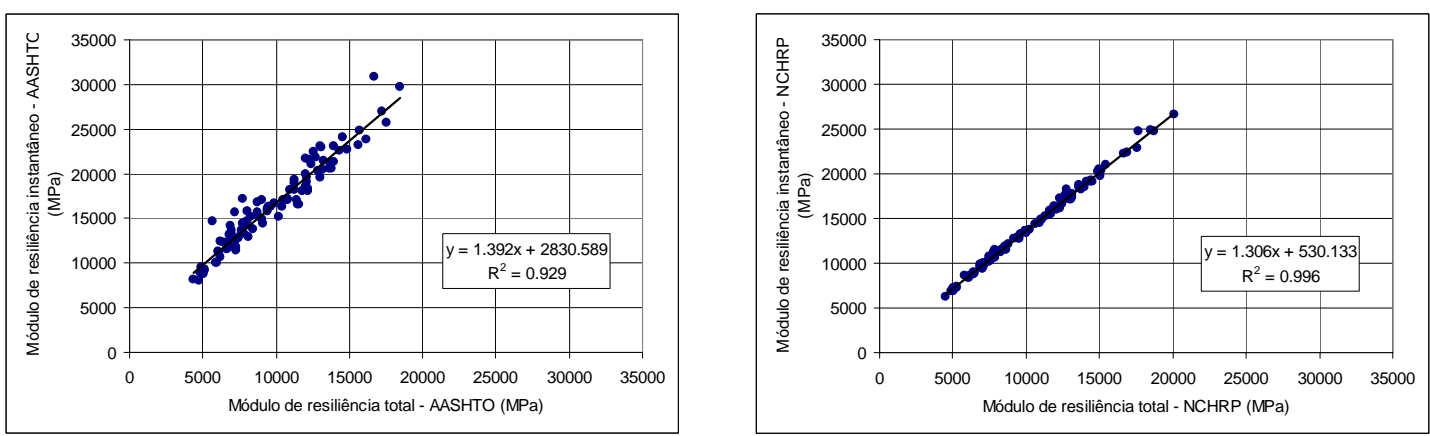

Figura 4.22: Relações entre os módulos de resiliência totais e instantâneos determinados segundo os procedimentos da AASHTO (esquerda) e do NCHRP (direita), para todas as condições do experimento. 
Observando-se a Figura 4.22 nota-se que a melhor correspondência entre os valores dos módulos totais e instantâneos foi a obtida para o procedimento da NCHRP, indicando que esse procedimento é mais consistente para o cálculo do módulo instantâneo, conforme já observado por Furlan (2006).

\subsubsection{Resultados das análises estatísticas do experimento fatorial}

\subsubsection{Considerações iniciais}

Como já explicitado anteriormente, foi executado um experimento fatorial que considerou o efeito de cinco fatores, em diversos níveis, nos valores dos módulos de resiliência e outros parâmetros deles decorrentes. Foram considerados os seguintes fatores e respectivos níveis de variação: tipo de agregado, em três níveis (basalto, granito e gabro); temperatura de ensaio, em três níveis $\left(10,25\right.$ e $\left.40^{\circ} \mathrm{C}\right)$; teor de asfalto efetivo, em três níveis $(5,0,5,5$ e $6,0 \%$ em peso); presença de aditivo, em dois níveis (sem e com cal) e tipo de asfalto, em dois níveis (CAP 20 e CAP 40), totalizando 108 condições de ensaio $(3 \times 3 \times 3 \times 2 \times 2)$, nas quais as três temperaturas foram apenas condicionamentos térmicos executados nos mesmos corpos-deprova, ou seja, houve reaproveitamento.

Assim, foram moldados 108 corpos-de-prova, que foram submetidos a ensaios de módulo de resiliência, nas três temperaturas fixadas, perfazendo 324 ensaios, que representam, portanto, três réplicas para cada uma das 108 condições experimentais. Após a execução dos ensaios de módulo de resiliência, os corpos-de-prova foram submetidos ao ensaio de resistência à tração por compressão diametral, na temperatura de $25^{\circ} \mathrm{C}$, perfazendo, portanto, 108 ensaios, com 3 réplicas para cada condição ( $3 \times 3 \times 2 \times 2$ condições). 
A análise estatística do experimento fatorial foi executada com auxílio do programa MiniTab14® e os resultados são apresentados a seguir.

\subsubsection{Resistência à tração a $25^{\circ} \mathrm{C}$}

Na Figura 4.23 são apresentados os gráficos dos efeitos principais dos fatores considerados no experimento nos valores médios das resistências à tração. Nela observa-se que todos os fatores exercem efeito nos valores médios das RTs, em maior ou menor intensidade. Observando-se essa figura nota-se que a mudança no tipo de asfalto, de CAP 20 para CAP 40 há um aumento significativo no valor médio da $\mathrm{RT}(\approx 33 \%)$. Com relação à cal nota-se que seu efeito é bastante discreto, indicando que a presença da cal reduz a RT média. Quanto ao teor de asfalto pode-se afirmar que há um ponto de máximo, correspondente ao teor de 5,5\%. Já com relação aos agregados, a análise não pode ser feita da mesma forma, pois o gráfico indica os valores médios das RTs em função do tipo de agregado, que são, em ordem crescente, gabro, granito e basalto. 


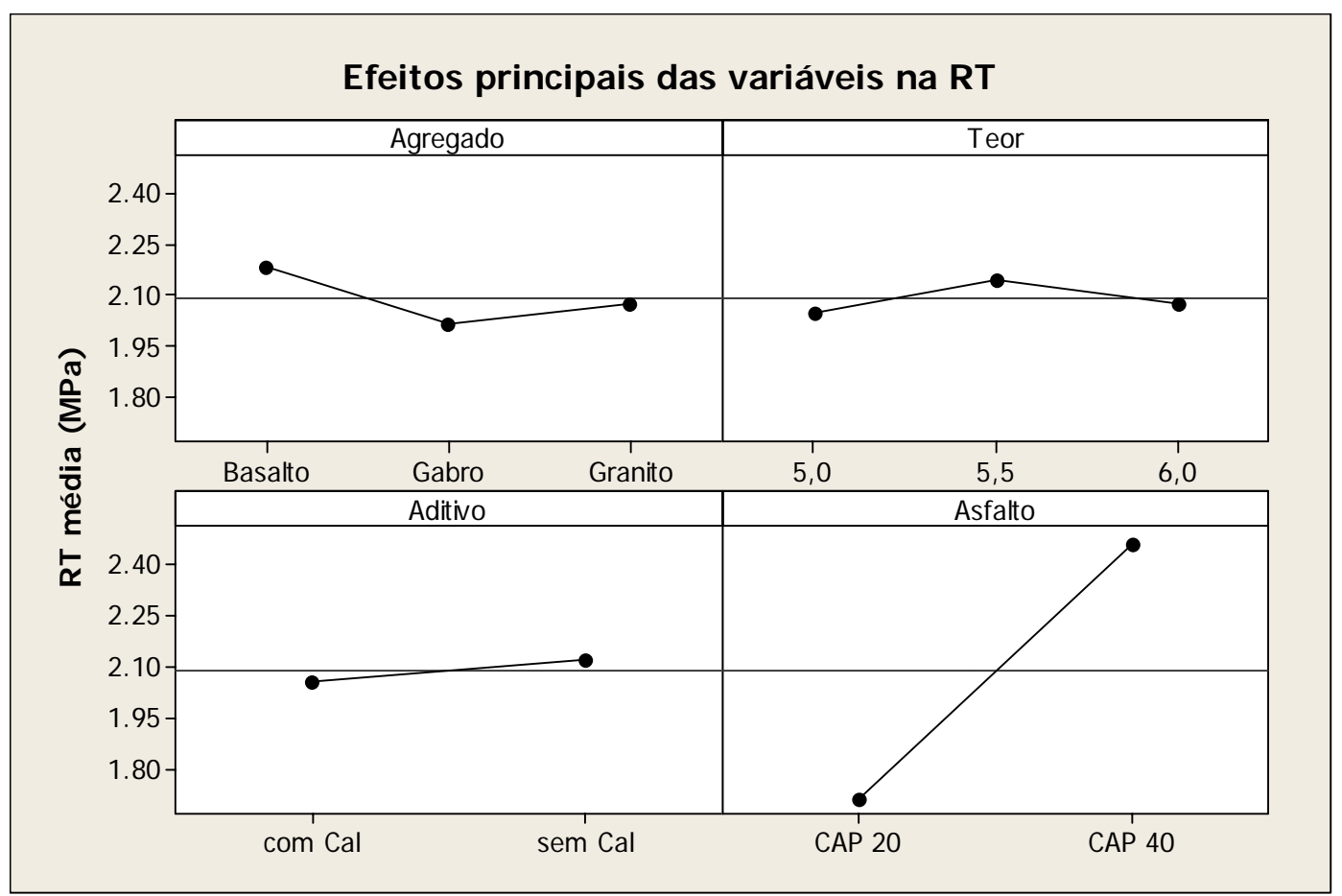

Figura 4.23: Efeitos principais dos fatores nos valores médios das resistências à tração

A Figura 4.24 apresenta o efeito das interações entre os fatores considerados nos valores médios da RT a $25^{\circ} \mathrm{C}$.

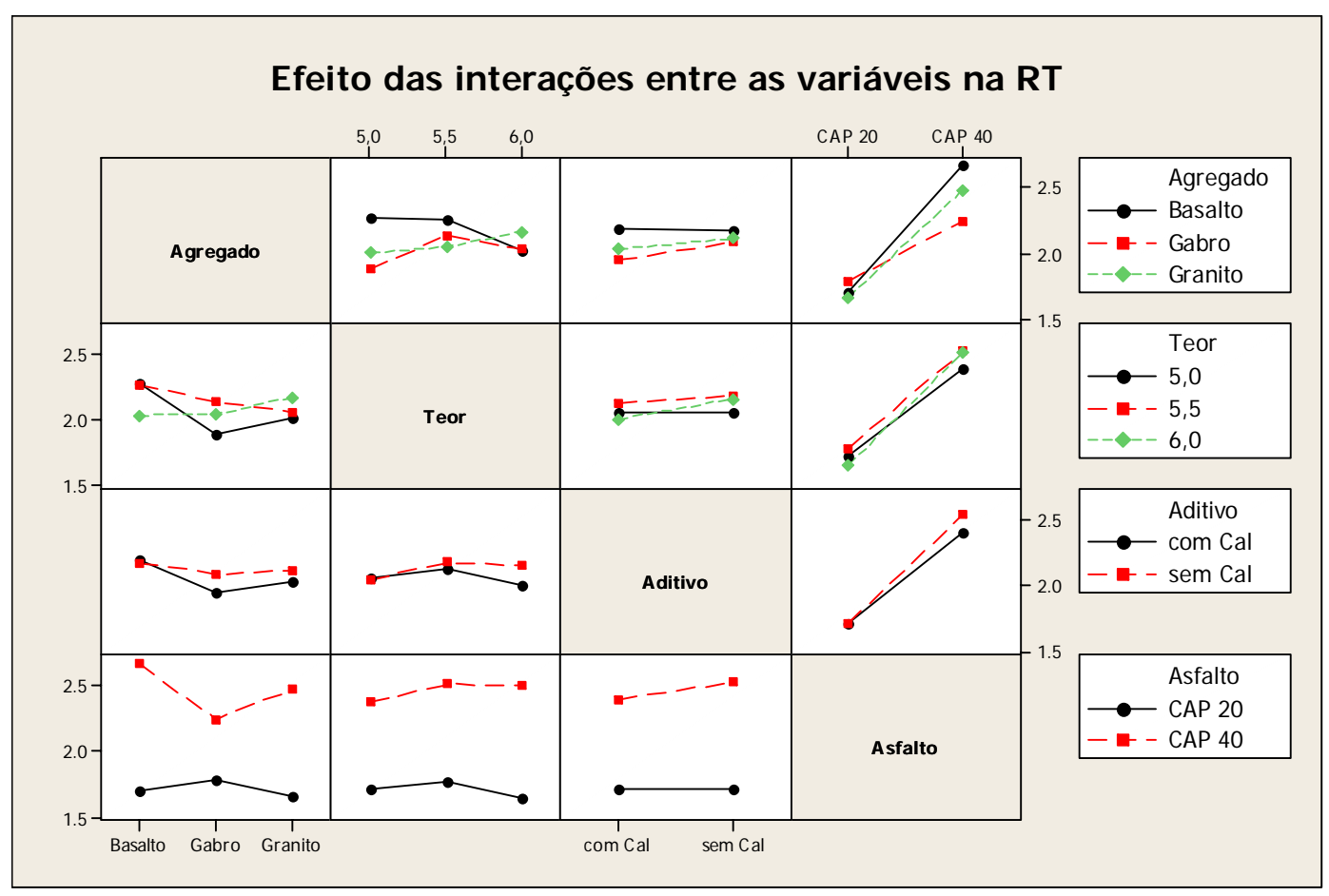

Figura 4.24: Efeitos das interações entre os fatores na resistência à tração a $25^{\circ} \mathrm{C}$. 
A titulo de exemplo, observando a Figura 4.24 pode-se verificar que a presença da cal em conjunto com os outros fatores se reflete da seguinte forma no valor da RT: com relação ao tipo de asfalto, não há influência no caso do CAP 20 e reduz para o CAP 40; quanto ao teor de asfalto, não exerce influência para 5,0\% e reduz para os outros dois teores e, com relação ao tipo de agregado, é indiferente para o basalto e reduz para os outros dois agregados.

A partir da análise estatística de experimento fatorial concluiu-se que os fatores que são significativos na variação do valor da RT são o agregado, o teor, o aditivo e o asfalto e as interações entre fatores consideradas significativas foram as entre agregado e teor, agregado e asfalto, aditivo e asfalto. A titulo de exemplo, a seguir é apresentado na expressão (4.1) um modelo para previsão do valor da RT a partir dos fatores considerados no experimento, que não leva em consideração as interações entre os fatores, por motivos de simplicidade. O coeficiente de determinação ajustado obtido para esse modelo foi de $76,5 \%$ e para o modelo completo (não apresentado) foi de $88,15 \%$. Os valores dos variáveis devem ser escolhidos, para cada caso, segundo a Tabela 4.7:

$$
\begin{aligned}
\mathbf{R T}= & 2,09046+0,09231 \times \mathrm{A}-0,07491 \times \mathrm{B}-0,04213 \times \mathrm{X}+0,05648 \mathrm{xD}-0,03287 \mathrm{xE}- \\
& -0,37509 \mathrm{xF}
\end{aligned}
$$

Tabela 4.7: Valores das variáveis do modelo para previsão da RT

\begin{tabular}{cccccccccccc} 
& \multicolumn{4}{c}{} & \multicolumn{4}{c}{ Agregado } & \multicolumn{4}{c}{ Teor de asfalto } & \multicolumn{2}{c}{ Aditivo } & \multicolumn{2}{c}{ Asfalto } \\
\cline { 2 - 12 } Variável & Basalto & Granito & Gabro & $\mathbf{5 , 0}$ & $\mathbf{5 , 5}$ & $\mathbf{6 , 0}$ & sem cal & com cal & CAP 20 & CAP 40 \\
\hline A & 1 & -1 & 0 & - & - & - & - & - & - & - \\
\hline B & 0 & -1 & 1 & - & - & - & - & - & - & - \\
\hline C & - & - & - & 1 & 0 & -1 & - & - & - & - \\
\hline D & - & - & - & 0 & 1 & -1 & - & - & - & - \\
\hline E & - & - & - & - & - & - & 1 & -1 & - & - \\
\hline F & - & - & - & - & - & - & - & - & 1 & -1 \\
\hline
\end{tabular}




\subsubsection{Módulo de resiliência total a $25^{\circ} \mathrm{C}$ (AASHTO)}

$\mathrm{Na}$ Figura 4.25 são apresentados os efeitos principais dos fatores considerados no experimento nos valores médios dos módulos de resiliência. Nela observa-se que a mudança no tipo de asfalto, de CAP 20 para CAP 40, causa um aumento de mais que 50\% no valor do módulo de resiliência. Com relação à cal, nota-se que ela não exerce efeito significativo. Quanto ao teor de asfalto, pode-se afirmar que seu aumento implica em decréscimo nos valores dos MRs. Já com relação aos agregados, o gráfico indica que as misturas com basalto apresentaram os menores módulos, seguidas das com gabro e, finalmente, pelas com granito.

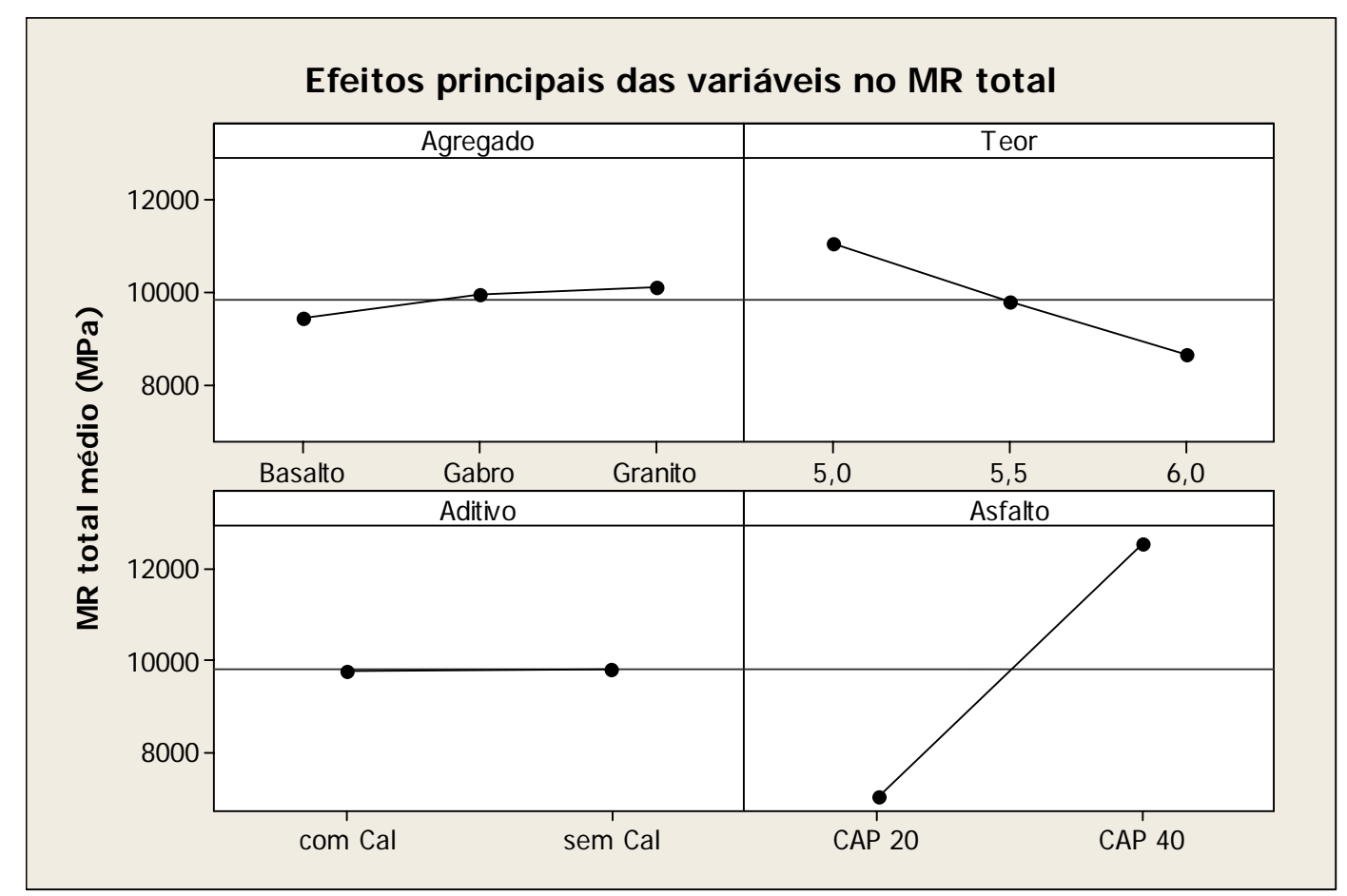

Figura 4.25: Efeitos principais dos fatores nos valores médios dos módulos de resiliência totais (AASHTO) a $25^{\circ} \mathrm{C}$.

A Figura 4.26 apresenta o efeito das interações entre os fatores considerados no experimento nos valores médios do módulo de resiliência. 


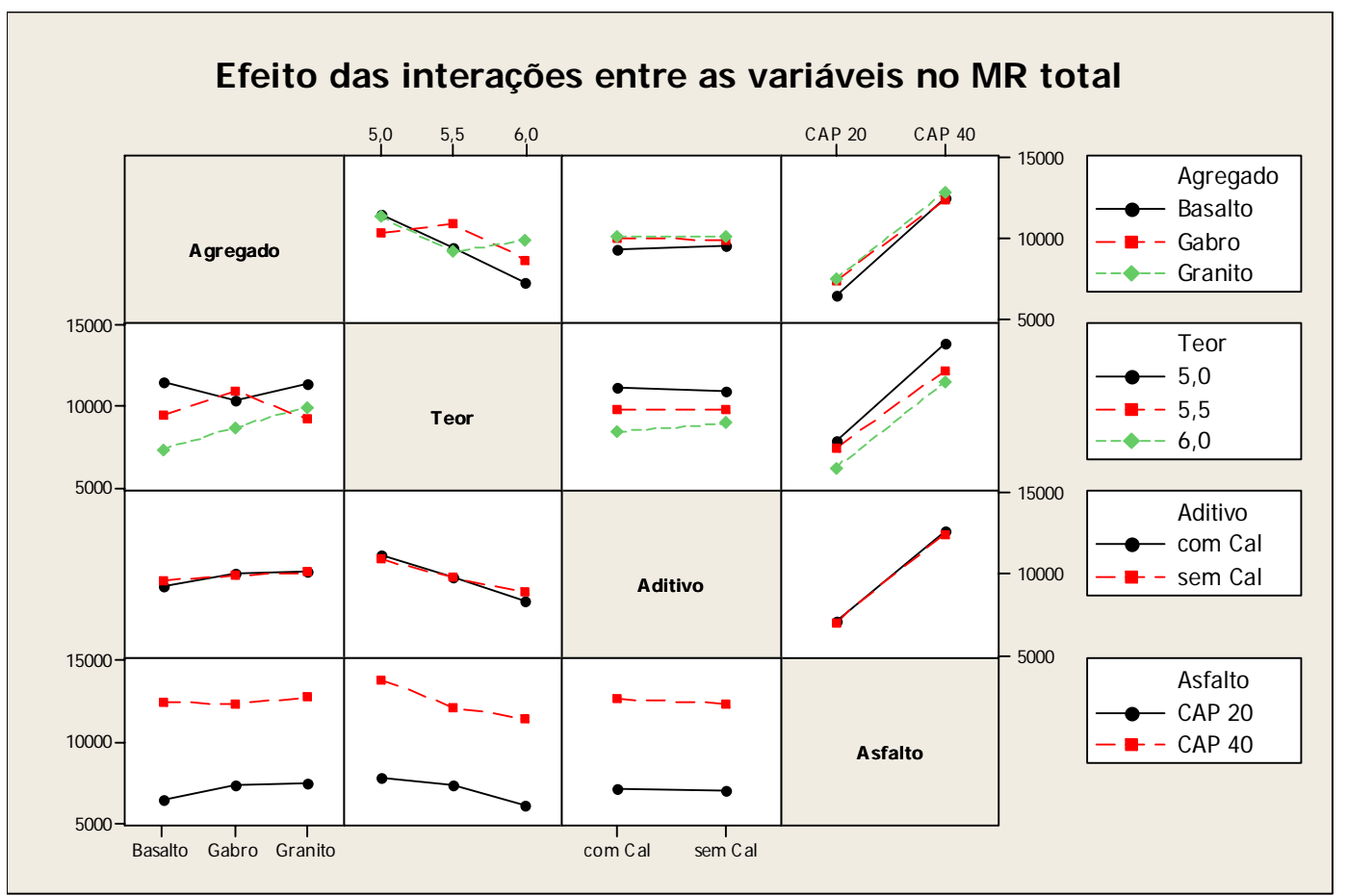

Figura 4.26: Efeitos das interações entre as variáveis no módulo de resiliência total (AASHTO) a $25^{\circ} \mathrm{C}$.

Como exemplo de interpretação dos resultados apresentados na Figura 4.26, pode-se analisar da cal (aditivo), onde se percebe que a sua presença praticamente não modifica os valores do MR, mesmo atuando em conjunto com outros fatores considerados no experimento.

Da análise estatística para produção de modelo de previsão do módulo de resiliência a $25^{\circ} \mathrm{C}$ a partir dos fatores considerados (sem consideração de interação entre fatores) obteve-se um coeficiente de determinação ajustado de $76,66 \%$, sendo considerados significativos os fatores teor e tipo de asfalto. Na expressão 4.2 é apresentado o modelo para a previsão do MR e os valores das variáveis a adotar são os da Tabela 4.7.

$$
\begin{aligned}
\mathrm{MR}= & 9842,0-353,1 \mathrm{xA}+27,5 \mathrm{xB}+1064,2 \mathrm{xC}-23,7 \mathrm{xD}+57,4 \mathrm{xE}- \\
& -2699,9 \mathrm{xF}
\end{aligned}
$$




\subsubsection{Relação MR total / RT a $25^{\circ} \mathrm{C}$}

Na Figura 4.27 são apresentados os efeitos principais dos fatores nos valores médios das relações MR total / RT a $25^{\circ} \mathrm{C}$. Nela observa-se que a mudança no tipo de asfalto, de CAP 20 para CAP 40, causa um aumento da ordem de 30\% nessa relação. Com relação à cal, nota-se que ela não exerce um efeito discreto, aumentando a relação MR/RT com a sua presença. Quanto ao teor de asfalto, pode-se afirmar que seu aumento implica em decréscimo nos valores das MR/RTs. Já para os agregados, o gráfico indica que as misturas com basalto apresentaram as menores relações, seguidas das com granito e, finalmente, pelas com gabro.

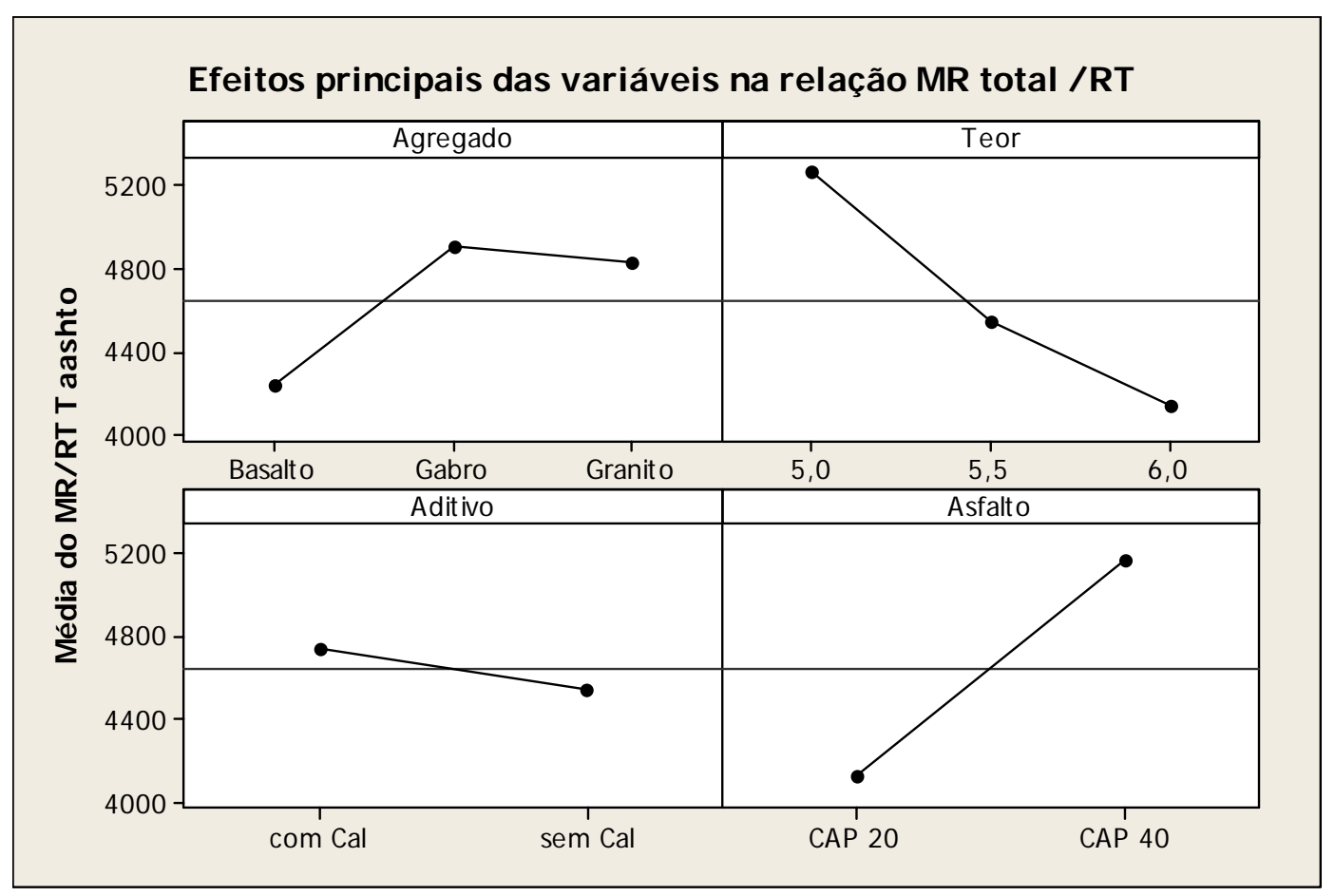

Figura 4.27: Efeitos principais das variáveis nos valores médios das relações MR total / RT a $25^{\circ} \mathrm{C}$.

A Figura 4.28 apresenta o efeito das interações entre os fatores considerados no experimento nos valores médios do módulo de resiliência. 
Como exemplo de análise dos resultados apresentados na Figura 4.28, pode-se verificar que o tipo de asfalto tem uma influência significativa nos valores da MR/RT.

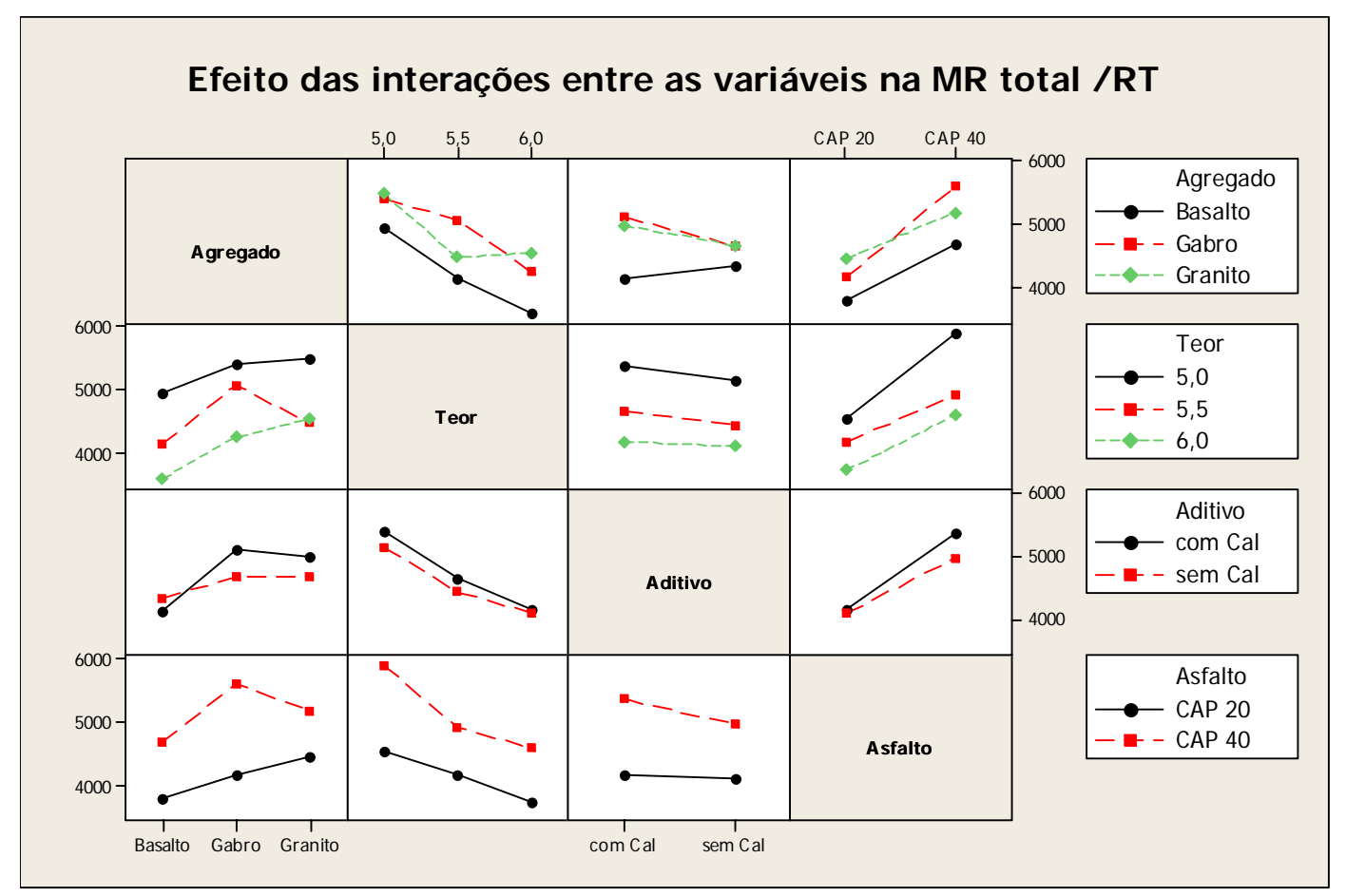

Figura 4.28: Efeitos das interações entre as variáveis nas relações MR total / RT a $25^{\circ} \mathrm{C}$.

Quanto à análise estatística, o modelo de previsão dos valores das relações MR/RT a $25^{\circ} \mathrm{C}$ obtido é de baixa qualidade (sem consideração de interação entre fatores), com um coeficiente de determinação ajustado de 49,06\%, sendo considerados significativos os fatores agregado, teor e tipo de asfalto. $\mathrm{Na}$ expressão 4.3 é apresentado o modelo para a previsão da relação MR/RT. Para seu uso deve-se utilizar os valores das variáveis apresentados na Tabela 4.7.

$$
\mathrm{MR} / \mathrm{RT}=4654,6-414,9 \mathrm{xA}+229,6 \mathrm{xB}+591,4 \mathrm{xC}-97,6 \mathrm{xD}+95,7 \mathrm{xE}-492,9 \mathrm{xF}
$$




\subsubsection{Módulo de resiliência total (AASHTO)}

Na Figura 4.29 são apresentados os efeitos principais de todos os fatores considerados no experimento (incluindo a temperatura) nos valores médios dos módulos de resiliência. Nela pode-se observar que, à semelhança do já apresentado anteriormente, a mudança de CAP 20 para CAP 40, causa um aumento de mais que 50\% no valor do módulo de resiliência. A cal praticamente não exerce efeito significativo. Quanto ao teor de asfalto, pode-se dizer que o aumento de 5,0\% para 6,0\% causa um decréscimo nos valores dos MRs de aproximadamente 33\%. Com relação aos agregados, o gráfico indica que há pouca influência nos módulos. Já com relação à temperatura, a influência parece ser a maior, já que uma elevação na temperatura de 10 para $25^{\circ} \mathrm{C}$ causa uma redução no $\mathrm{MR}$ da ordem de $60 \%$ e, novamente, uma elevação de 25 para $40^{\circ} \mathrm{C}$ causa outra redução de, aproximadamente, $50 \%$.

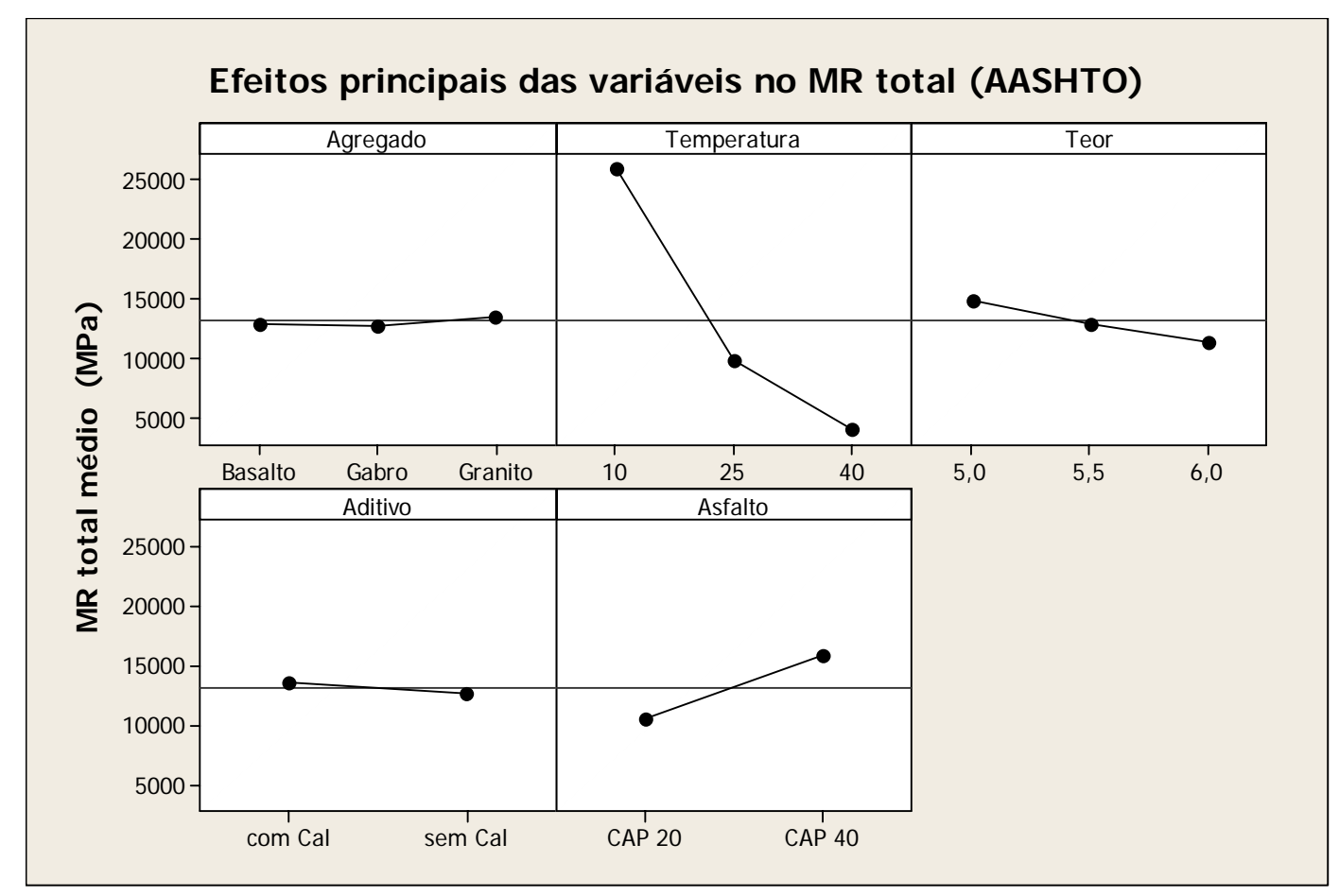

Figura 4.29: Efeitos principais dos fatores nos valores médios dos módulos de resiliência totais (AASHTO). 
A Figura 4.30 apresenta o efeito das interações entre todos os fatores considerados no experimento nos valores médios do módulo de resiliência.

Novamente, como exemplo de interpretação dos resultados apresentados na Figura 4.30, pode-se analisar o efeito do tipo de asfalto que, para todas as interações com os outros componentes do experimento, eleva o valor do módulo significativamente quando da mudança do CAP 20 para o CAP 40.

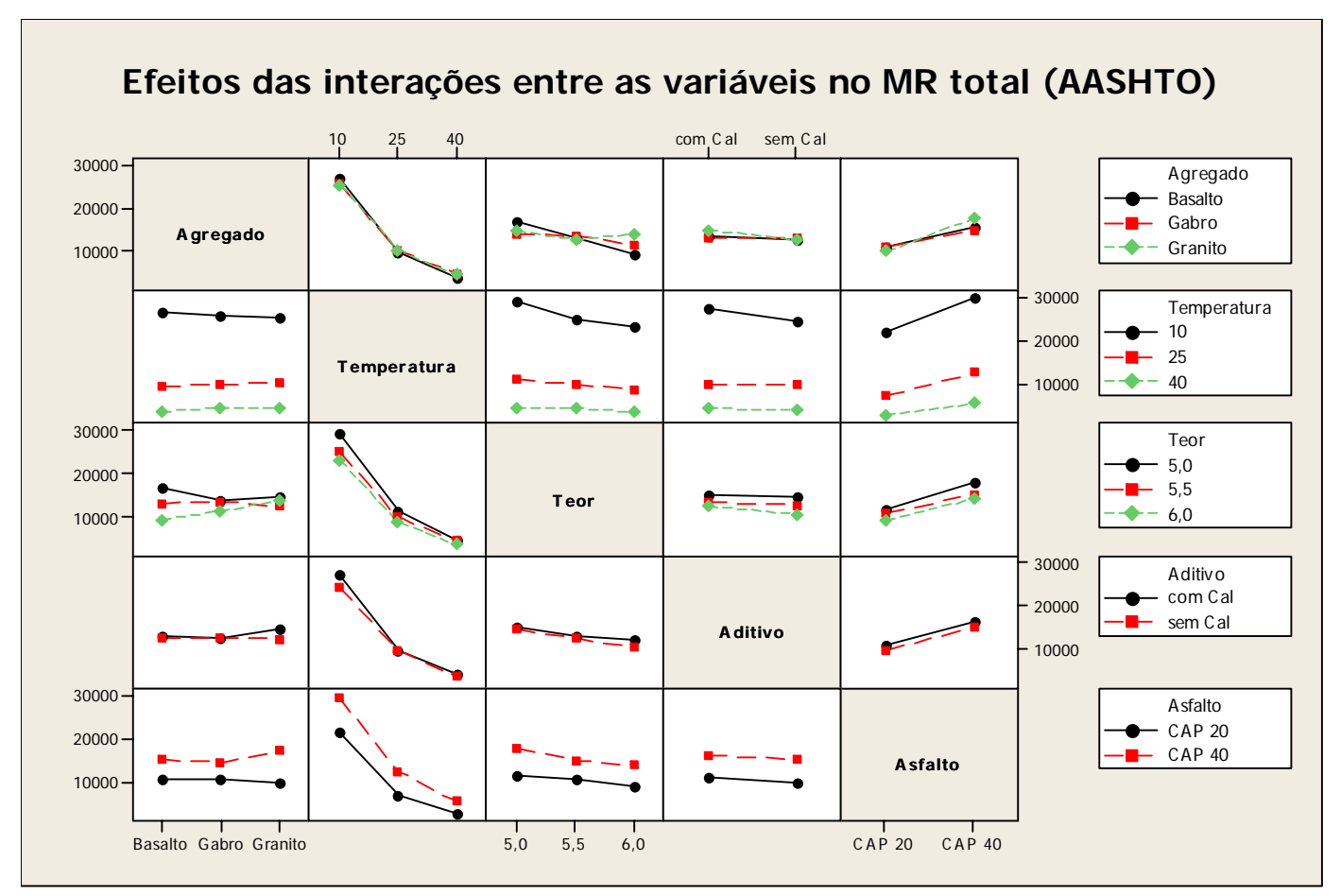

Figura 4.30: Efeitos das interações entre as variáveis no módulo de resiliência total (AASHTO).

O modelo de previsão do módulo de resiliência (sem consideração de interação entre fatores), obtido a partir da análise estatística, é apresentado na expressão 4.4, com um coeficiente de determinação ajustado de $86,58 \%$ e foram considerados significativos a temperatura, teor, aditivo e asfalto, ou seja, o agregado não tem influência significativa nos valores médios dos 
módulos de resiliência. Os valores das variáveis a utilizar no modelo da expressão 4.4 são os apresentados na Tabela 4.8 .

$$
\begin{aligned}
\mathbf{M R}= & 13267,3+48,0 \times \mathrm{xA}-76,3 \mathrm{xB}+1674,1 \mathrm{xC}-279,4 \mathrm{xD}+624,0 \mathrm{xE}-2714,6 \mathrm{xF}+ \\
& +12649,0 \mathrm{xG}-3441,4 \mathrm{xH}
\end{aligned}
$$

\begin{tabular}{|c|c|c|c|c|c|c|c|c|c|c|c|c|c|}
\hline \multirow[b]{2}{*}{ Variável } & \multicolumn{3}{|c|}{ Agregado } & \multicolumn{3}{|c|}{$\begin{array}{c}\begin{array}{c}\text { Teor de asfalto } \\
(\%)\end{array} \\
\end{array}$} & \multicolumn{2}{|c|}{ Aditivo } & \multicolumn{2}{|c|}{ Asfalto } & \multicolumn{3}{|c|}{$\begin{array}{c}\text { Temperatura } \\
\left({ }^{\circ} \mathrm{C}\right)\end{array}$} \\
\hline & Basalto & Granito & Gabro & 5,0 & 5,5 & 6,0 & $\begin{array}{c}\text { sem } \\
\text { cal }\end{array}$ & $\begin{array}{c}\text { com } \\
\text { cal }\end{array}$ & $\begin{array}{c}\text { CAP } \\
20 \\
\end{array}$ & $\begin{array}{c}\text { CAP } \\
40\end{array}$ & 10 & 25 & 40 \\
\hline A & 1 & -1 & 0 & - & - & - & - & - & - & - & & & \\
\hline $\mathrm{B}$ & 0 & -1 & 1 & - & - & - & - & - & - & - & & & \\
\hline $\mathrm{C}$ & - & - & - & 1 & 0 & -1 & - & - & - & - & & & \\
\hline $\mathrm{D}$ & - & - & - & 0 & 1 & -1 & - & - & - & - & & & \\
\hline $\mathrm{E}$ & - & - & - & - & - & - & 1 & -1 & - & - & & & \\
\hline $\mathrm{F}$ & - & - & - & - & - & - & - & - & 1 & -1 & & & \\
\hline $\mathrm{G}$ & & & & & & & & & & & 1 & 0 & -1 \\
\hline $\mathrm{H}$ & & & & & & & & & & & 0 & 1 & -1 \\
\hline
\end{tabular}

Tabela 4.8: Valores das variáveis para previsão da MR total em todas as temperaturas

\subsubsection{Recuperação Retardada}

Com o intuito de aproveitar, ao máximo, os resultados obtidos do programa experimental, optou-se por incluir os resultados da Recuperação Retardada, já que o programa de processamento dos ensaios de módulo de resiliência dão também, como saída, os valores desse parâmetro. Segundo FURLAN (2006), a Recuperação Retardada (RR) "representa a recuperação no período de repouso e é indiretamente relacionada com a visco-elasticidade do material. Com RR podem-se verificar alterações de comportamento das misturas asfálticas quanto à forma da resposta resiliente e, inclusive, por exemplo, pode-se observar se um aumento do valor do módulo de resiliência implicou em misturas asfálticas mais elásticas ou mais viscosas". 
O parâmetro RR é obtido a partir das expressões 4.5 e 4.6.

$$
\begin{gathered}
R R=\frac{\left(M R_{I}-M R_{T}\right)}{M R_{I}} \times 100 \\
R R=\frac{\frac{\sigma}{\varepsilon_{I}}-\frac{\sigma}{\varepsilon_{T}}}{\frac{\sigma}{\varepsilon_{I}}}=\frac{\frac{\varepsilon_{T}-\varepsilon_{i}}{\varepsilon_{I} \varepsilon_{T}}}{\varepsilon_{I}}=\frac{\varepsilon_{T}-\varepsilon_{I}}{\varepsilon_{T}} \times 100
\end{gathered}
$$

Em que:

RR é a recuperação retardada, em \%;

$\mathrm{MR}_{\mathrm{I}}$ é o módulo instantâneo, em MPa;

$\mathrm{MR}_{\mathrm{T}}$ é o módulo total, em MPa;

$\sigma$ é a tensão aplicada;

$\varepsilon_{\mathrm{T}}$ é a deformação total;

$\varepsilon_{\text {I }}$ é a deformação elástica instantânea.

Na Figura 4.31 são apresentados os efeitos principais de todos os fatores (incluindo a temperatura) nos valores médios da Recuperação Retardada. Nela pode-se observar que só exercem efeitos claramente visíveis na Recuperação Retardada a temperatura e o teor de asfalto. À medida que a temperatura ou o teor de asfalto aumentam, aumenta a Recuperação Retardada e a mistura perde resposta elástica na recuperação, ou seja, na composição da deformação total há uma diminuição na parcela cuja recuperação é instantânea e um aumento na parcela cuja recuperação é visco-elástica, ou que se processa ao longo do tempo. Outras observações interessantes dizem respeito aos efeitos do tipo de asfalto e da cal (aditivo); a 
mudança de CAP 20 para CAP 40 gera uma resposta ligeiramente mais elástica nas misturas e o acréscimo de cal produz efeito contrário a esse, ou seja, torna a mistura um pouco mais viscosa.

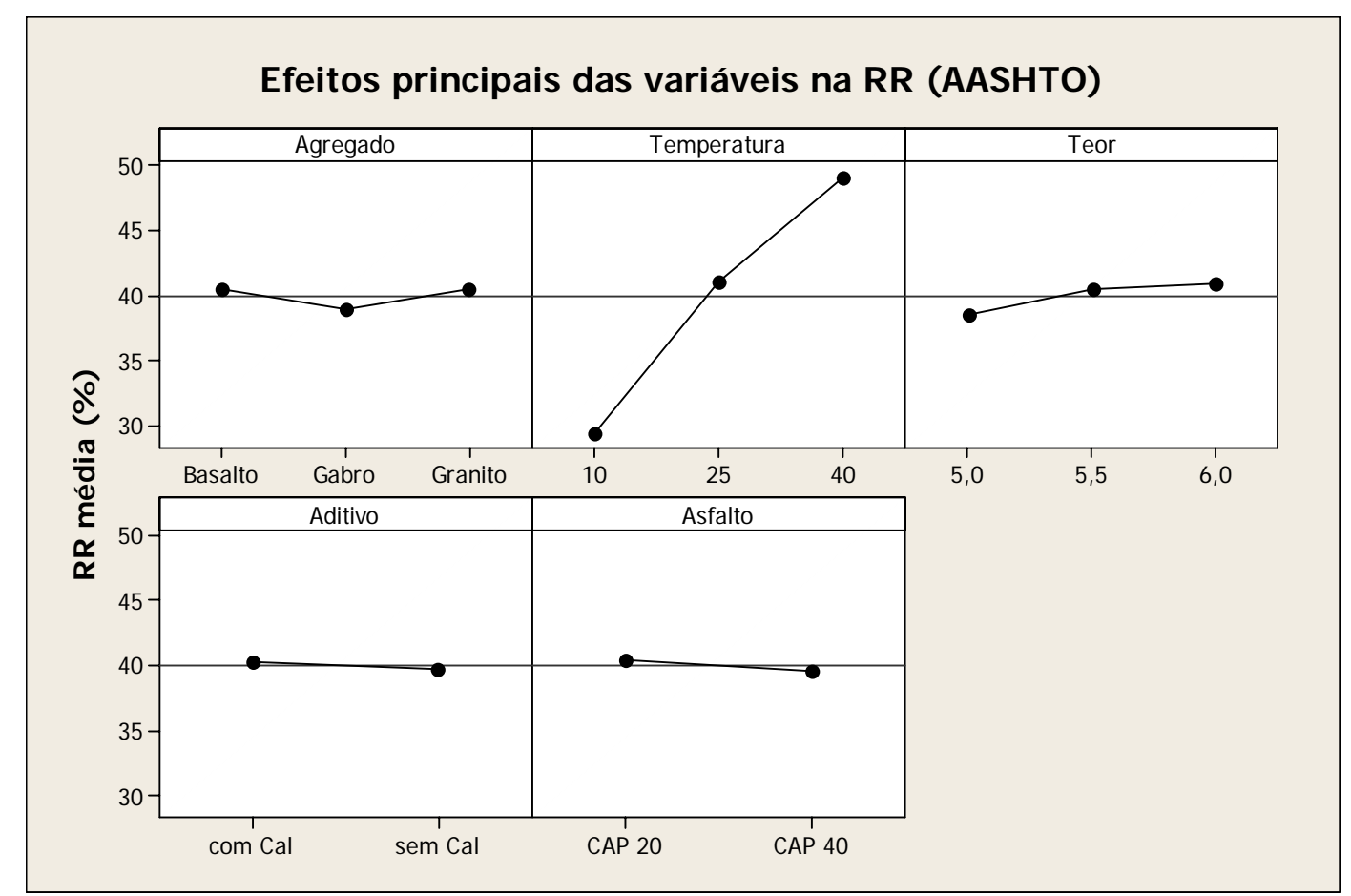

Figura 4.31: Efeitos principais dos fatores nos valores médios da Recuperação Retardada.

Na Figura 4.32 são apresentados os efeitos das interações entre todos os fatores considerados no experimento sobre os valores médios da Recuperação Retardada.

Como exemplo de interpretação dos resultados apresentados na Figura 4.32, pode-se observar o efeito da cal que praticamente não influencia os valores da RR, ou do tipo de asfalto que, ora produz efeito num sentido (crescente, por exemplo), ora em outro sentido. Já, por exemplo, a temperatura ou o teor de asfalto produzem efeitos sempre num mesmo sentido, com seus aumentos há aumento na RR. 


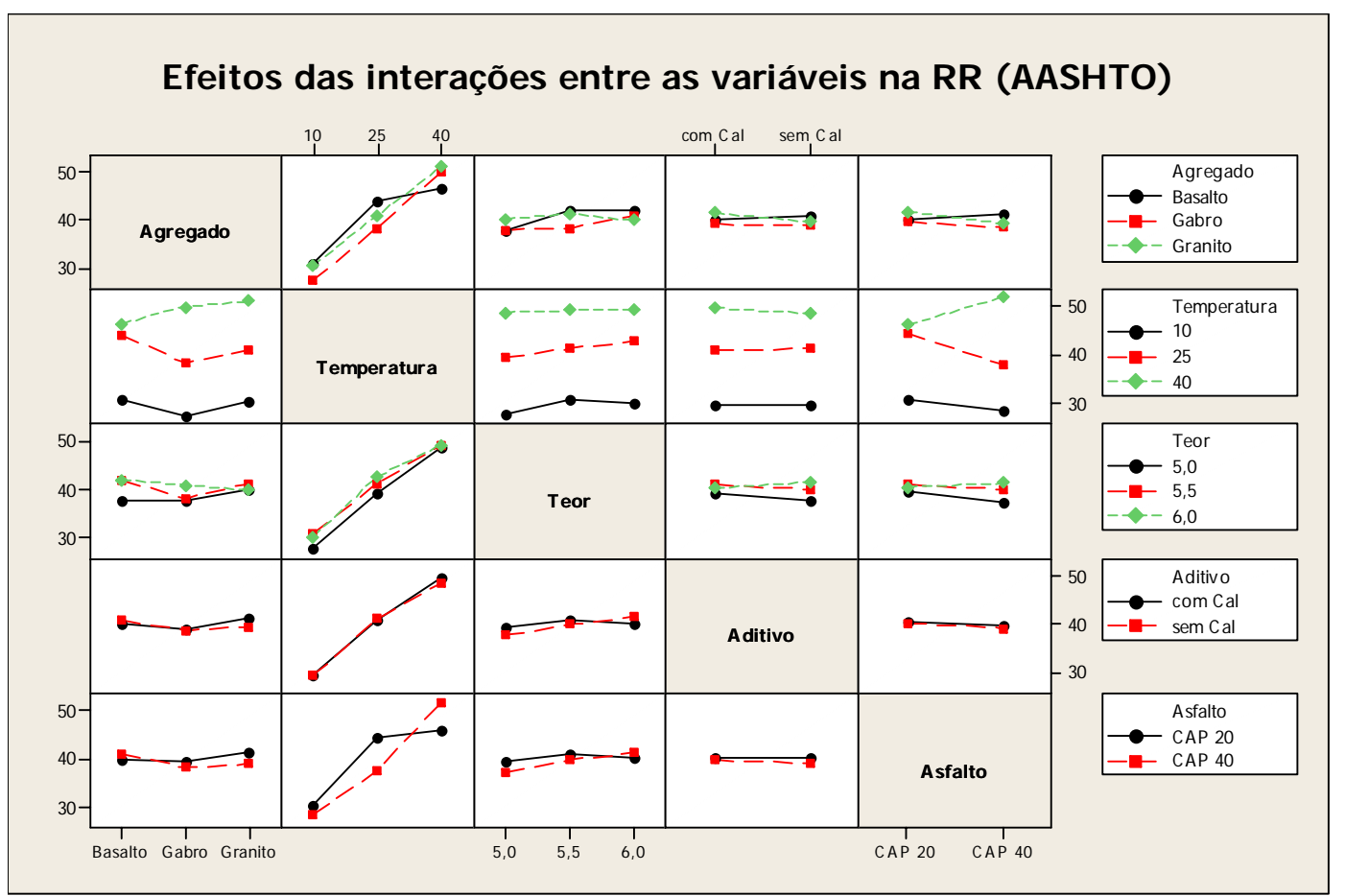

Figura 4.32: Efeitos das interações entre as variáveis na Recuperação Retardada.

O modelo de previsão da Recuperação Retardada - RR (sem consideração de interação entre fatores), obtido da análise estatística, é apresentado na expressão 4.5, com um coeficiente de determinação ajustado de $70,44 \%$. Os fatores considerados significativos foram o agregado, a temperatura e o teor de asfalto, ou seja, o tipo de asfalto não tem efeito significativo nos valores médios da RR. Os valores das variáveis a utilizar no modelo da expressão 4.5 são os apresentados na Tabela 4.8.

$$
\begin{aligned}
\mathbf{R R}= & 39,874+0,478 \times \mathrm{A}-1,325 \mathrm{xB}-1,335 \mathrm{xC}+0,538 \mathrm{xD}+0,199 \mathrm{xE}+0,453 \times \mathrm{F}- \\
& -10,428 \mathrm{xG}+1,212 \times \mathrm{H}
\end{aligned}
$$

\subsubsection{Atraso}

De forma similar à adotada em relação à Recuperação Retardada, resolveu-se incluir também o parâmetro Atraso. Segundo Furlan (2006), “outro parâmetro determinado a partir dos 
ensaios de módulo de resiliência é chamado de atraso e é expresso em segundos. O atraso é uma medida da defasagem entre os pulsos de carga e os de deslocamento. Foi calculado com base na diferença de tempo entre o ponto de máximo valor de deslocamento e o tempo no ponto de carga máxima. Como na RR, esse parâmetro tem relação com a viscoelasticidade do material, mas nesse caso a resposta é avaliada no período de carregamento, para a obtenção do atraso foi necessária uma rotina especial de cálculo que foi incorporado ao programa de determinação do módulo de resiliência. Tanto o programa de cálculo de MR quanto a rotina adicional para cálculo do atraso foram criadas pelo Prof. Dr. Glauco Tulio Pessa Fabbri em linguagem Labview $7.1^{\circledR}$,

Na Figura 4.33 são apresentados os efeitos principais de todos os fatores nos valores médios do Atraso. Nela pode-se observar que só exercem efeitos claramente visíveis no Atraso a temperatura e o tipo de asfalto. À medida que a temperatura ou a consistência do asfalto aumentam, aumenta o Atraso, ou seja, a mistura torna-se mais viscosa. Os outros fatores praticamente não exercem efeitos visíveis nesse parâmetro. 


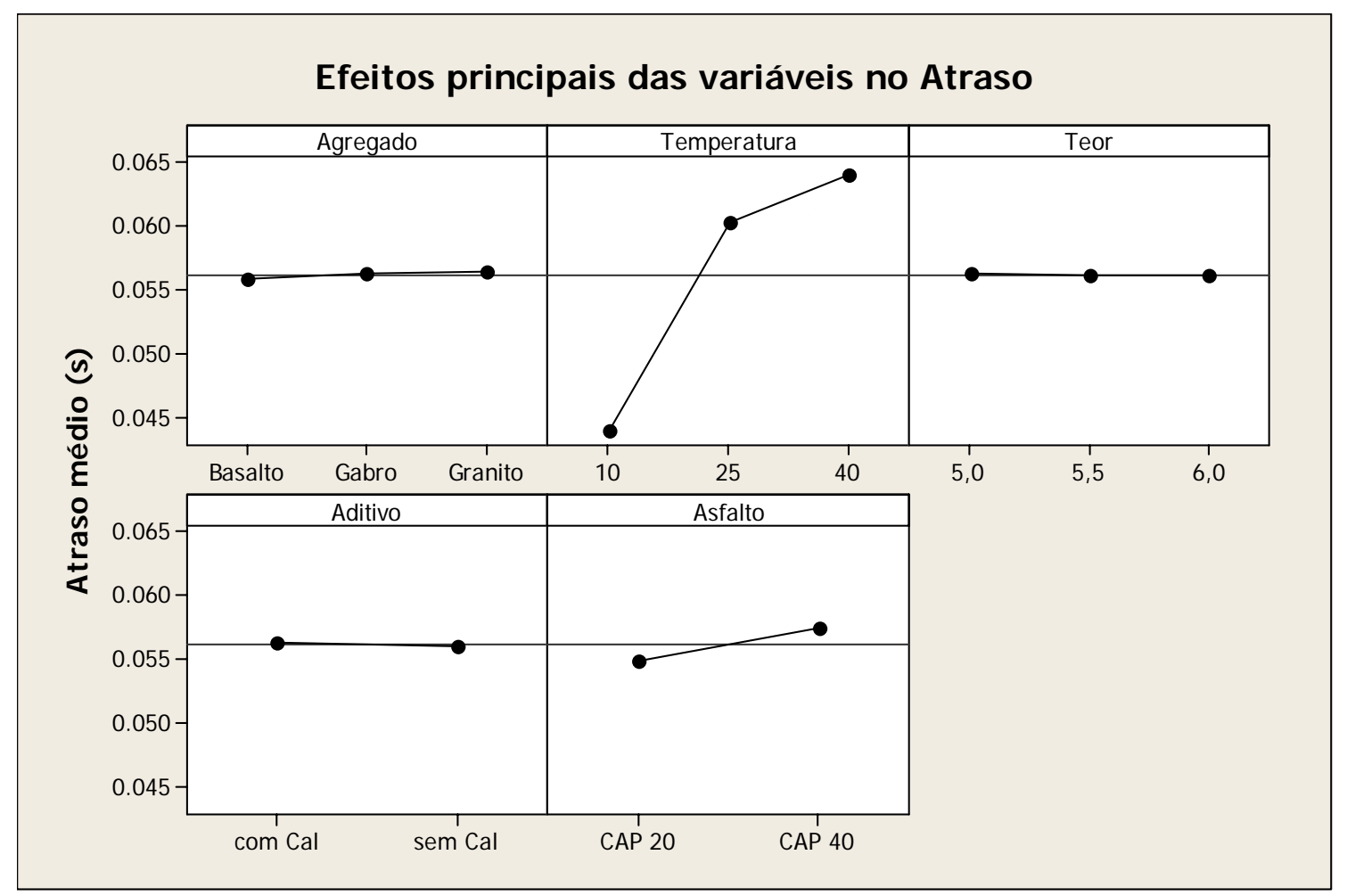

Figura 4.33: Efeitos principais dos fatores nos valores médios do Atraso.

Na Figura 4.34 são apresentados os efeitos das interações entre todos os fatores considerados no experimento sobre os valores médios do Atraso. Como exemplo de interpretação dos resultados apresentados nessa figura, pode-se observar o efeito da temperatura nos valores do Atraso, onde nota-se que seu aumento reflete-se diretamente em aumentos no Atraso, ou seja, as misturas tornam-se mais viscosa. 


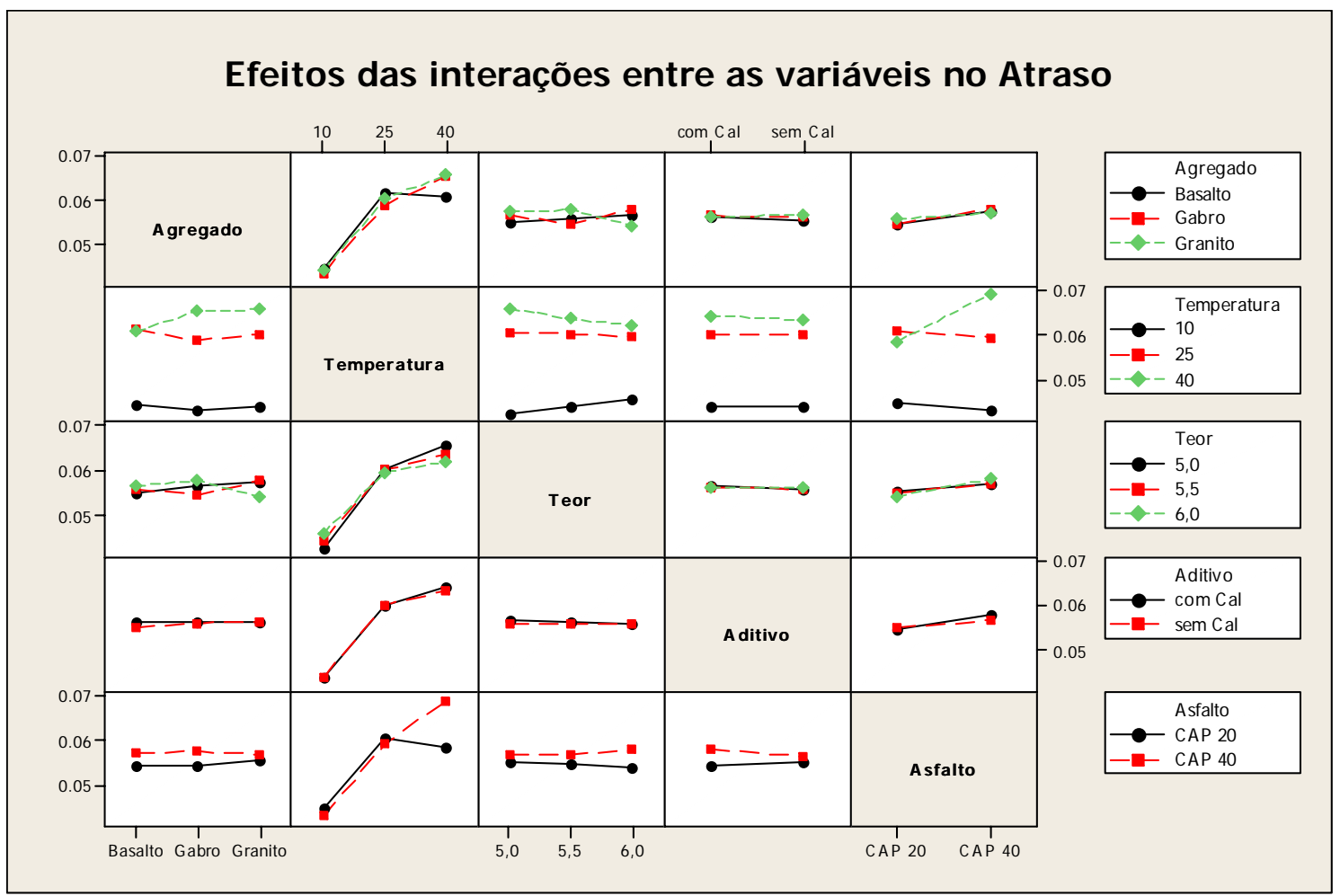

Figura 4.34: Efeitos das interações entre as variáveis no Atraso.

O modelo de previsão do atraso (“At”, sem consideração de interação entre fatores), obtido da análise estatística, é apresentado na expressão 4.6, e teve um coeficiente de determinação ajustado igual a $68,15 \%$. Os fatores considerados significativos foram somente a temperatura e o tipo de asfalto. Os valores das variáveis a utilizar no modelo da expressão 4.6 são os apresentados na Tabela 4.8.

$$
\begin{aligned}
\mathbf{A t}= & 0,056046-0,000422 \times \mathrm{A}-0,000264 \mathrm{xB}+0,000229 \mathrm{xC}-0,000046 \mathrm{xD}+0,000196 \mathrm{xE} \\
& -0,001205 \mathrm{xF}-0,012030 \mathrm{xG}+0,004148 \times \mathrm{H}
\end{aligned}
$$

\subsection{CONSIDERAÇÕES FINAIS}

Nesse capítulo foram apresentados alguns dos resultados obtidos a partir dos experimentos laboratoriais executados durante a pesquisa, principalmente em relação aos obtidos do Programa II. Além dos resultados ora apresentados, há também dados acerca dos módulos de 
resiliência instantâneo obtido segundo a AASHTO, módulos de resiliência total e instantâneo obtidos segundo o NCHRP, valores respectivos das relações MR/RT, RRs, etc. Esses resultados podem ser encontrados no Apêndice III. 


\section{CAPÍTULO 5 CONCLUSÕES}

\subsection{CONSIDERAÇÕES INICIAIS}

Durante o desenvolvimento dessa pesquisa foram executados dois programas de pesquisa que objetivavam avaliar a influência das condições ambientais no enrijecimento de misturas asfálticas densas (Programa I) e o efeito de alguns fatores na susceptibilidade térmica de misturas asfálticas densas, tais como teor e tipo de asfalto, tipo de agregado, presença de cal e temperatura de ensaio (Programa II). Nos dois programas, a propriedade monitorada foi o módulo de resiliência total das misturas asfálticas produzidas. Adicionalmente, no Programa II, foram avaliadas outras propriedades de interesse à engenharia, tais como resistência à tração por compressão diametral, volume de vazios e outros valores de módulos de resiliência determinados para outras condições e/ ou métodos. A seguir são apresentados as principais conclusões obtidas de cada um dos programas experimentais implementados.

\subsection{CONCLUSÕES ACERCA DO PROGRAMA I: AVALIAÇÃO DOS EFEITOS DAS CONDIÇÕES AMBIENTAIS NO ENRIJECIMENTO DE MISTURAS ASFÁLTICAS DENSAS}

Esse programa teve a finalidade de avaliar os efeitos que certas condições ambientais exercem no valor do módulo de resiliência de misturas asfálticas densas ao longo de um período de 
estocagem. Foram consideradas cinco condições ambientais, a saber: ao ar e à luz (AAAL), ao ar e sem luz (AASL), sob baixa pressão atmosférica e à luz (AVAL), sob baixa pressão atmosférica e sem luz (AVSL) e ao clima e às intempéries (CLIMA). Todas as conclusões baseiam-se na observação dos resultados apresentados no capítulo anterior, que sintetizam as médias dos valores dos módulos de resiliência de quatro corpos-de-prova produzidos para cada uma das condições ambientais testadas. A seguir são apresentadas as principais conclusões obtidas desse Programa:

- não há efeito significativo causado pela exposição ou não dos corpos-de-prova à luz artificial (condições AL e SL);

- não há efeito significativo nos valores dos módulos de resiliência causado pela exposição ou não dos corpos-de-prova ao ar (condições AA e AV);

- o tempo de exposição, para quaisquer das condições climáticas consideradas, exerce efeito significativo nos valores dos módulos de resiliência;

- o valores dos módulos de resiliência crescem com o tempo, de maneira acelerada no início do período (primeiros sete dias) e depois tendem a se estabilizarem em níveis que representam acréscimos de até 50\% em relação aos valores iniciais;

- quando se considera no efeito da exposição à luz também a condição CLIMA, ou seja, quando se consideram as três condições AL, SL e CLIMA, essa exposição passa a exercer efeito significativo nos valores dos módulos de resiliência;

- comparando-se os valores médios dos módulos de resiliência dos cinco grupos testados ao longo de todo o período de observação pode-se afirmar que as condições climáticas artificiais produzem efeitos similares, elevando os valores médios dos 
módulos a patamares similares e próximos de $12.000 \mathrm{MPa}$ e que a condição clima foi a que produziu valor médio menor, da ordem de $11.000 \mathrm{MPa}$.

\subsection{CONCLUSÕES ACERCA DO PROGRAMA II: AVALIAÇÃO DO EFEITO DE} ALGUNS FATORES NA SUSCEPTIBILIDADE TÉRMICA DE MISTURAS ASFÁLTICAS DENSAS

Este programa de pesquisa teve a finalidade de avaliar a influência de alguns fatores na susceptibilidade térmica de misturas asfálticas. Os fatores considerados foram: tipo de agregado (basalto, gabro e granito), tipo de asfalto (CAP 20 e CAP 40), teor de asfalto $(5,0$, 5,5 e 6,0\%), presença de aditivo (com e sem cal) e temperaturas de ensaio $\left(10,25\right.$ e $\left.40^{\circ} \mathrm{C}\right)$. A seguir são apresentadas as principais conclusões extraídas desse Programa:

Quanto ao volume de vazios:

- de uma maneira geral, o uso do CAP 40 produziu valores médios de volumes de vazios maiores que os produzidos pelo CAP 20;

- também de uma maneira geral, o uso de cal produziu valores médios de volumes de vazios menores que os produzidos sem adição de cal;

- quanto ao efeito do tipo de agregado, os menores valores médios dos volumes de vazios foram obtidos para as misturas com basalto, independente do tipo de asfalto utilizado ou da presença ou não de cal; já as misturas de granito sem cal produziram volumes de vazios maiores que as de gabro sem cal e as de granito com cal, valores menores que as de gabro com cal. 
Quanto à resistência à tração $(\mathrm{RT}) \mathrm{a} 25^{\circ} \mathrm{C}$ :

- os teores de asfalto intermediários (5,5\%) produziram, em média, as maiores resistências à tração;

- o uso do CAP 40 sempre produziu valores médios de resistência à tração maiores que os produzidos pelo CAP 20;

- de uma maneira geral, o uso de cal produziu valores médios de resistência à tração menores que os produzidos sem adição de cal;

- quanto ao efeito do tipo de agregado, de uma maneira geral, as misturas com gabro foram as que exibiram menores resistências à tração, seguidas pelas de granito e pelas de basalto.

Quanto ao módulo de resiliência (MR):

- de uma maneira geral, o módulo de resiliência diminui com o aumento do teor de asfalto;

- o uso de CAP 40 sempre produz módulos de resiliência maiores que os produzidos pela utilização de CAP 20;

- o módulo de resiliência sempre diminui com o aumento da temperatura de ensaio, sendo a queda mais acentuada dos $10^{\circ} \mathrm{C}$ para os $25^{\circ} \mathrm{C}$ do que dos $25^{\circ} \mathrm{C}$ para os $40^{\circ} \mathrm{C}$;

- aparentemente o tipo de agregado não produziu efeito significativo nos valores dos módulos de resiliência;

- a adição de cal produziu um aumento muito discreto nos valores dos módulos de resiliência. 
Quanto à relação módulo de resiliência / resistência à tração $(\mathrm{MR} / \mathrm{RT})$ a $25^{\circ} \mathrm{C}$ :

- de uma maneira geral, a relação MR / RT diminui com o aumento do teor de asfalto;

- também de uma maneira geral, a relação MR / RT é maior para as misturas com cal, ou seja, a adição de cal pode aumentar os valores das relações MR / RT;

- as misturas com basalto foram as que apresentaram valores da relação MR / RT menores, seguidas das com granito e, posteriormente, das com gabro;

- de uma maneira geral, a utilização de CAP 40 produz relações MR / RT maiores que as com CAP 20.

Além dessas conclusões, foi observada, ainda, a existência de relações bem definidas, do ponto de vista estatístico, entre os valores do módulo de resiliência total obtido pelo procedimento da AASHTO e o módulo de resiliência instantâneo obtido pelo mesmo método, assim como com os outros obtidos pelo método do NCHRP. Foram também desenvolvidos modelos estatísticos que permitem estimar os valores da resistência à tração a $25^{\circ} \mathrm{C}$, do módulo de resiliência a $25^{\circ} \mathrm{C}$ ou em uma das três temperaturas de ensaio utilizadas $(10,25$ e $40^{\circ} \mathrm{C}$ ), da relação MR/RT a $25^{\circ} \mathrm{C}$, da Recuperação Retardada e do Atraso. 


\section{REFERÊNCIAS BIBLIOGRÁFICAS}

AASHTO PP 2 - Standard Practice for Mixture Conditioning of Hot Mix Asphalt (HMA). American Association of State Highway and Transportation officials, 2001.

ABNT (1993). NBR 12891. Dosagem de Misturas Betuminosas pelo Método Marshall. Associação brasileira de Normas Técnicas. 12p. Rio de Janeiro, 1993.

ABNT EB 78. Materiais Betuminosos - Determinação da Penetração.

ABNT MB 827. Materiais Betuminosos - Determinação da Viscosidade Absoluta.

ABNT NBR - 6576/98. Materiais Betuminosos - Determinação da Penetração

ASTM (1982). D 4123-82. Standard Method of Indirect Tension Test for Resilient Modulus of Bituminous Mixtures. American Society for Testing and Materials. 5p. Philadelphia, 1982.

ASTM (1993). C 128-93. Standard Method for Specific Gravity, and Absorption of fine Aggregate. American Society for Testing and Materials. 5p. Philadelphia, 1993.

ASTM (2001). C 127-01. Standard Method for Density, Relative Density (Specific Gravity), and Absorption of Coarse Aggregate. American Society for Testing and Materials. 6p. Philadelphia, 2001.

BAYOMI, F.M. (1992). Development of Analysis of Cement-coated Aggregate for Asphalt Mixtures. Effects of Aggregates and Mineral Fillers on Asphalt Mixture Performance. Special Technical Publication STP 1147, American Society for Testing Materials (ASTM), p.19-34 Meininger, R.C., editor. Philadelphia.

BARKSDALE, R.D.; ALBA, J. (1997) Laboratory Determination of Resilient Modulus for Flexible Pavement Design. Prepared for: National Cooperative Highway Research Program (NCHRP). Georgia. 
BELL, C.A. (1989). Summary Report on: Aging of Asphalt-Aggregates Systems. Publicação SR-OSU-A-003A-89-2 do Strategic Highway Research Program. National Research Council. p.121. Washington, D.C.

BUTTON, J.W. (1996). Permeability of Asphalt Surface Seals and their Effect on Aging of Underlying Asphalt Concrete. Transportation Research Record. n 1535, p. 124-130. Washington, D.C.

DER -SP (1970). Método de Ensaio M 34 - 70 - Determinação do Índice de Lamelaridade de Agregados. Departamento de Estradas de Rodagem do Estado de São Paulo. 4p. São Paulo, 1970

DER SP (1991) Manual de Normas, Pavimentação. Seção 3.13, Camada de Rolamento de Concreto Asfáltico e Camada Intermediária ("binder") Asfáltica Usinada a Quente. DER-SP 1991.

DNER (1994a). Método de Ensaio ME 133/94. Misturas Betuminosas - Determinação do Módulo de Resiliência. Departamento Nacional de Estradas de Rodagem. 5p. Rio de Janeiro, 1994.

DNER (1994b). Método de Ensaio ME 78/94. Agregado Graúdo - Adesividade a Ligante Betuminoso. Departamento Nacional de Estradas de Rodagem. 3p. Rio de Janeiro, 1994.

DNER (1994c). Método de Ensaio ME 79/94. Agregado - Adesividade a Ligante Betuminoso. Departamento Nacional de Estradas de Rodagem. 4p. Rio de Janeiro, 1994.

DNER (1995). Método de Ensaio ME 43/95. Misturas Betuminosas à Quente - Ensaio Marshall. Departamento Nacional de Estradas de Rodagem. 11p. Rio de Janeiro, 1995.

DNER (1997). Especificação de Serviço ES 313/97. Pavimentação - Concreto Betuminoso. Departamento Nacional de Estradas de Rodagem. 16p. Rio de Janeiro, 1997.

DNER (1998a). Departamento Nacional de Estradas de Rodagem. Pesquisa de asfaltos modificados por polímeros - Relatório final. Tomo I e II. 
DNER (1998b). Método de Ensaio ME 035/98. Agregado - Determinação da Abrasão Los Angeles . Departamento Nacional de Estradas de Rodagem. 6p. Rio de Janeiro, 1998.

FURLAN, A.P.; GIGANTE, A.C.; FABBRI, G.T.P. (2006). Estudo Comparativo do Módulo de Resiliência de Misturas Asfáltica Densas Determinado a Partir dos Procedimentos de Cálculo da AASHTO e da NCHRP. XX ANPET 2006. Brasília.

FURLAN, A.P.(2006). Considerações Acerca da Adesão e da Suscetibilidade à Umidade de Misturas Asfálticas Densas à Luz de Algumas Propriedades Mecânicas. Tese (Doutorado) - Escola de Engenharia de São Carlos, Universidade de São Paulo.127p. São Carlos, 2006

GARRICK, N.W. (1995). Nonlinear Differential Equation For Modeling Asphalt Aging. Journal of Materials in Civil Engineering. Volume 7, n.4. p.265-268.

GIGANTE, A.C.; FURLAN, A.P.; IWANAGA, F.I.; FABBRI, G.T.P. (2005). Sobre o efeito da Condição Ambiental no Enrijecimento de Mistura Asfáltica Densa. 36a ${ }^{\mathrm{a}}$. RAPv, Reunião Anual de Pavimentação, Curitiba.

GIGANTE, A.C.; FURLAN, A.P.; FABBRI, G.T.P. (2006) Avaliação da suscetibilidade Térmica de Misturas Asfálticas Densas à Luz de seus Comportamentos Resilientes. (2006). XX ANPET, Brasília.

GOLVEIA, L.T.; FURLAN, A.P.; PARREIRA, A.B.; FERNANDES Jr., J.L.; FABBRI, G.T.P. (2004) Considerações Acerca da Absorção de Asfalto pelos Agregados e sua Influência na Suscetibilidade à Umidade. XVI ANPET, Congresso nacional de Pesquisa e Ensino em Transportes, Florianópolis.

GUIMARÃES, J.E.P. (1985) As aplicações da cal nas Construções Civis. Associação Brasileira dos Produtores de Cal, 1985. 
JANOO, V.C.; KORHONEN. (1999). Performance Testing of Hot Mix Asphalt Aggregate. Special report 9-20. U.S. Army Corps of Engineers Cold Regions Research \& Engineering Laboratory, 1999.

KEMP, G.R.; SHERMAN, G.B. (1984).Significant Studies on Asphalt Durability: California Experience. Transportation Research Record. n 999, p.36-41. Washington, D.C.

KIM, Y.R.; KHOSLA, N.P. KIM, N. (1992) Effects of Aggregate Type and Gradation on Fatigue and Permanent Deformation of Asphalt Concrete. Effects of Aggregate and Mineral Fillers on Asphalt Mixture Performance. Special Technical Publication STP 1147, American Society for Testing Materials (ASTM), p 310-328. Meininger, R.C., editor, Philadelphia, 1992.

LEITE, L.F.M. (1990). Estudos Reológicos de Cimentos Asfálticos. Dissertação (Mestrado) - Universidade Federal do Rio de Janeiro. 122p. Rio de Janeiro, 1990.

LiTTLE, D.N.; EPPS, J.A. (2001). The Benefits of Hydrated Lime in Hot Mix Asphalt. National Lime Association. 54 p. 2001.

LIVNEH, M.; GREENSTEIN, J. (1972). Influence of Aggregate Shape on Engineering Properties os Asphalt Paving Mixtures. Highway Researcg Record 404, p. 45-56. Washington, D.C.

MAJIDZADEH, K.;BROVOLD, F.N. (1968). Stat of the Art: Effect of Water on BitumenAggregate Mixtures, Highway Research Board, Special Report No. 98, 77 p.

MONTEIRO, A.E.C. (1983). Uma Introdução à Visco-elasticidade. Dissertação (Mestrado) - Escola de Engenharia de São Carlos, Universidade de São Paulo. 87p. São Carlos, 1983.

MOURA, E. (2001). Estudo do Efeito de Aditivos Químicos e da Cal como Melhoradores de Adesividade em Misturas Asfálticas Densas. Dissertação (Mestrado) - Escola Politécnica, Universidade de São Paulo. p.94, figura 5.4. São Paulo, 2001. 
MOURÃO, F.A.L. (2003). Misturas Asfálticas de Alto Desempenho Tipo SMA. Dissertação (Mestrado). Universidade Federal do Rio de Janeiro. 151p. Rio de Janeiro, 2003.

PETERSEN, J.C. (1990). Effects of physicoquimical factors on asphalt aging Serviceability and Durabiliy of Construction Materials. Volume I. p.244-253.

PHROMSORN, C.J.;KENNEDY, T.W. (1996) Evaluation of Laboratory Methods Simulating Aging Effects of Asphalt Binder. Transport Research Board. Volume 1488.

POPP, J.H., (1984) Geologia Geral. Livros Técnicos e Científicos Editora S.A. $3^{\text {a }}$ Edição, 283p. 1984

SAID, L.; SAFWAT, F. (2005) Aging Effect on Mechanical Characteristics of Bituminous Mixtures. Transport Research Board. Annual Meeting CD-Rom. 2005.

SANDERS, C.A.; DUKATZ, E.L. (1992) Evaluation of Percent Fracture of Hot Mix asphalt Gravels in Indiana. Effects of Aggregates and Mineral Fillers on Asphalt Mixture Performance. Special Technical Publication STP 1147, American Society for Testing Materials (ASTM), p. 90-103, Meininger, R.C., editor Philadelphia.

SANTANNA-GRECO, J.A. (2004). Avaliação da Influencia de Alguns Fatores nas Propriedades Mecânicas de Misturas Asfálticas Densas, à Luz da Técnica de Planejamento e Analise de Experimentos Fatoriais Fracionários Assimétricos. Tese (Doutorado) - Escola de Engenharia de São Carlos, Universidade de São Paulo. 340p. São Carlos, 2004.

SEBALY, P.E.; McCANN. M. HITTI,E.; EPPS, J. (2001) Performance of Lime in Hot Mix asphalt Pavements. Pavements/Material Program -Departament of Civil Engineering University of Nevada, Technical Report Documentation Page, 101p. Distribuition Statement: Unrestricted. Nevada, 2001.

SOSNOVSKE, D.A.; ABWAHAB, Y.; BELL, C.A. (1993). Role of Asphalt and Aggregate in the Aging of Bituminous Mixtures. Transportation Research Record. n.1386, p.10-21. Washington, D.C., 1993. 
TAIRA, C. (2001). Avaliação do Desempenho em Laboratório de Misturas Asfálticas Densas Utilizando Asfalto Convencional (CAP-20) e Asfalto Modificado com Polímero SBS (Betuflex B 65/60). Dissertação (Mestrado) - Escola de Engenharia de São Carlos, Universidade de São Paulo. 153p. São Carlos, 2001.

TAIRA, C.; FURLAN, A.P.; FABBRI, G.T.P. (2003). Avaliação do Efeito do Asfalto Modificado com Polímero nas Propriedades Mecânicas de Misturas Asfálticas Densas. XVII Congresso de Pesquisa e Ensino em Transportes ANPET, 2003 Rio de Janeiro, RJ.

VERHASSELT, A.F.; CROQUET, F.S. (1993).Comparing Field and Laboratory Aging of Bitumens on a Kinetic Bases. Transportation Research Record. n 1391. p. 30-38

YOON, H.H.; TARRER, A.R. (1988). Effect of Aggregate Properties on Atripping. Transportation Research Record 1171, p. 37-43. Washington, D.C. 
APÊNDICE I: DOSAGENS MARSHALL DOS AGREGADOS BASALTO, GABRO E GRANITO COM CAP 20 


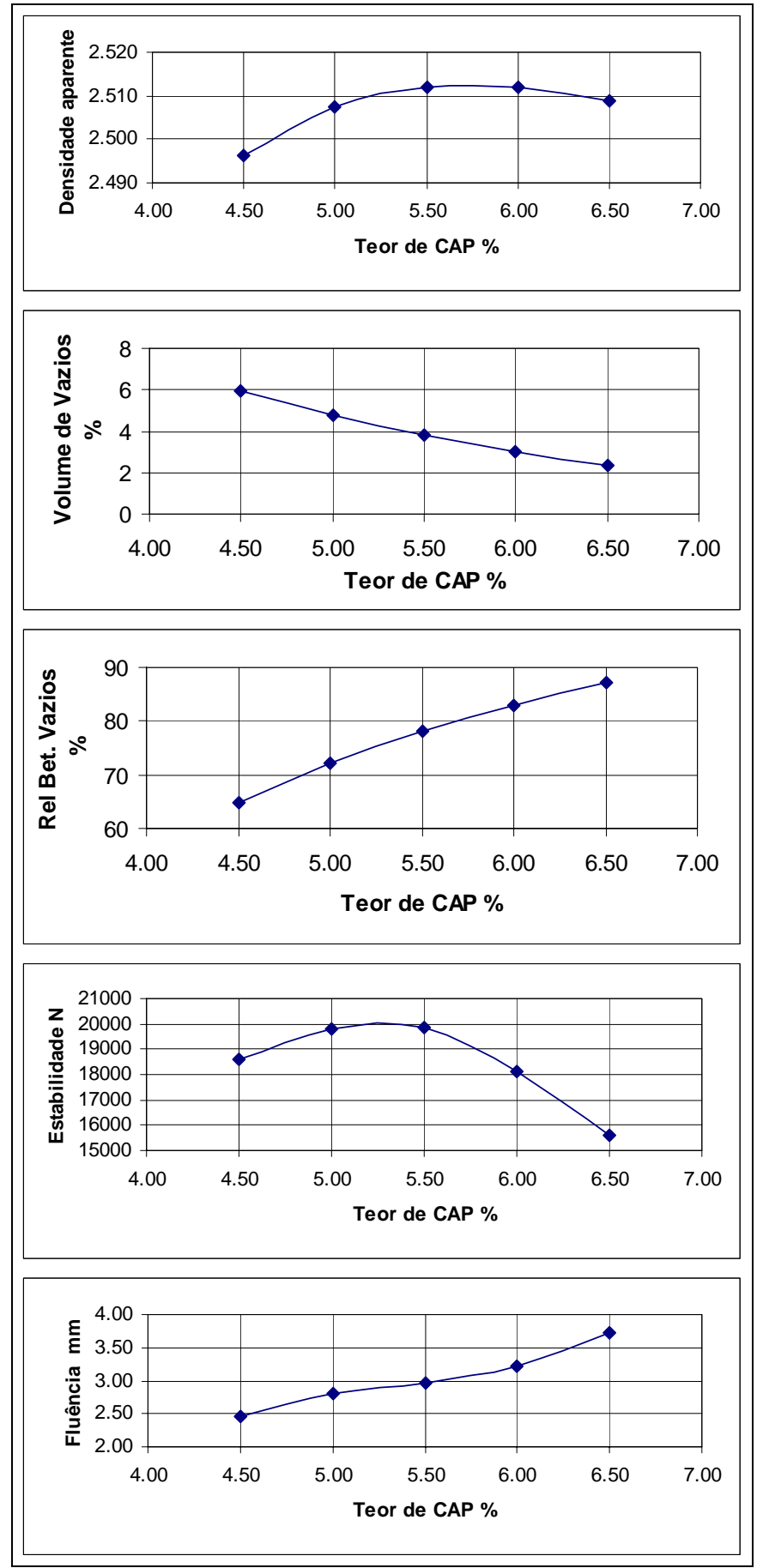

Figura I.1: Curvas da dosagem Marshall do Basalto.

Tabela I.1: Dados da dosagem do Basalto e CAP 20.

\begin{tabular}{cccccc}
\hline Teor CAP & Densidade aparente & Estabilidade.(N) & Fluência (mm) & Vv (\%) & RBV (\%) \\
\hline 4,50 & 2,496 & 18574 & 2,5 & 5,98 & 64,81 \\
5,00 & 2,507 & 19785 & 2,8 & 4,77 & 72,08 \\
5,50 & 2,512 & 19850 & 3,0 & 3,80 & 78,11 \\
6,00 & 2,512 & 18115 & 3,2 & 3,01 & 83,06 \\
6,50 & 2,509 & 15597 & 3,7 & 2,34 & 87,24 \\
\hline
\end{tabular}



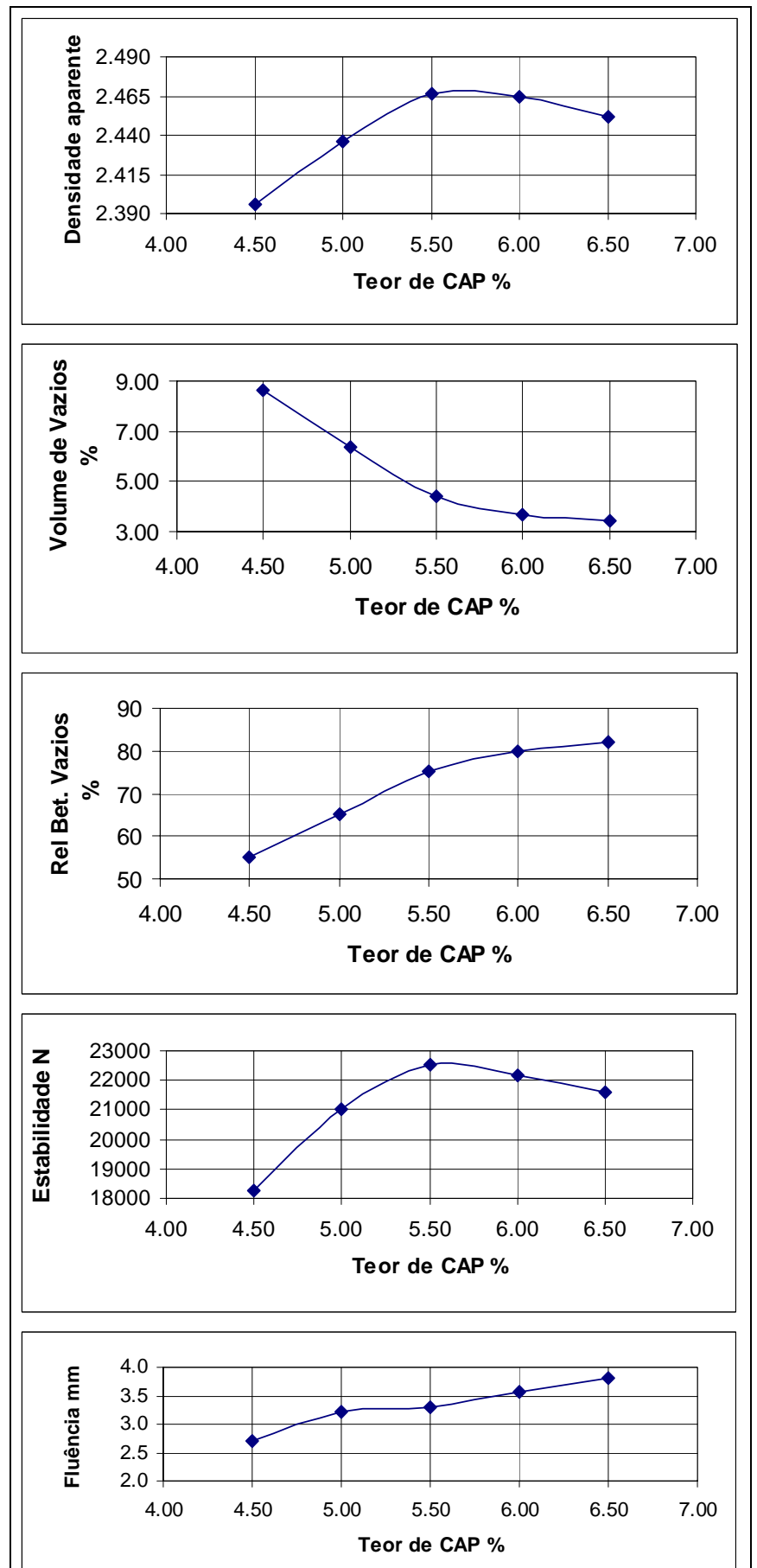

Figura I.2: Curvas da dosagem Marshall do Gabro.

Tabela I.2: Dados da dosagem do Gabro e CAP 20.

\begin{tabular}{cccccc}
\hline Teor CAP & Densidade aparente & Estabilidade.(N) & Fluência (mm) & Vv (\%) & RBV (\%) \\
\hline 4,50 & 2,395 & 18241 & 2,7 & 8,65 & 54,98 \\
5,00 & 2,436 & 21044 & 3,2 & 6,35 & 65,27 \\
5,50 & 2,467 & 22530 & 3,3 & 4,38 & 75,25 \\
6,00 & 2,465 & 22161 & 3,6 & 3,68 & 79,75 \\
6,50 & 2,452 & 21585 & 3,8 & 3,41 & 82,11 \\
\hline
\end{tabular}




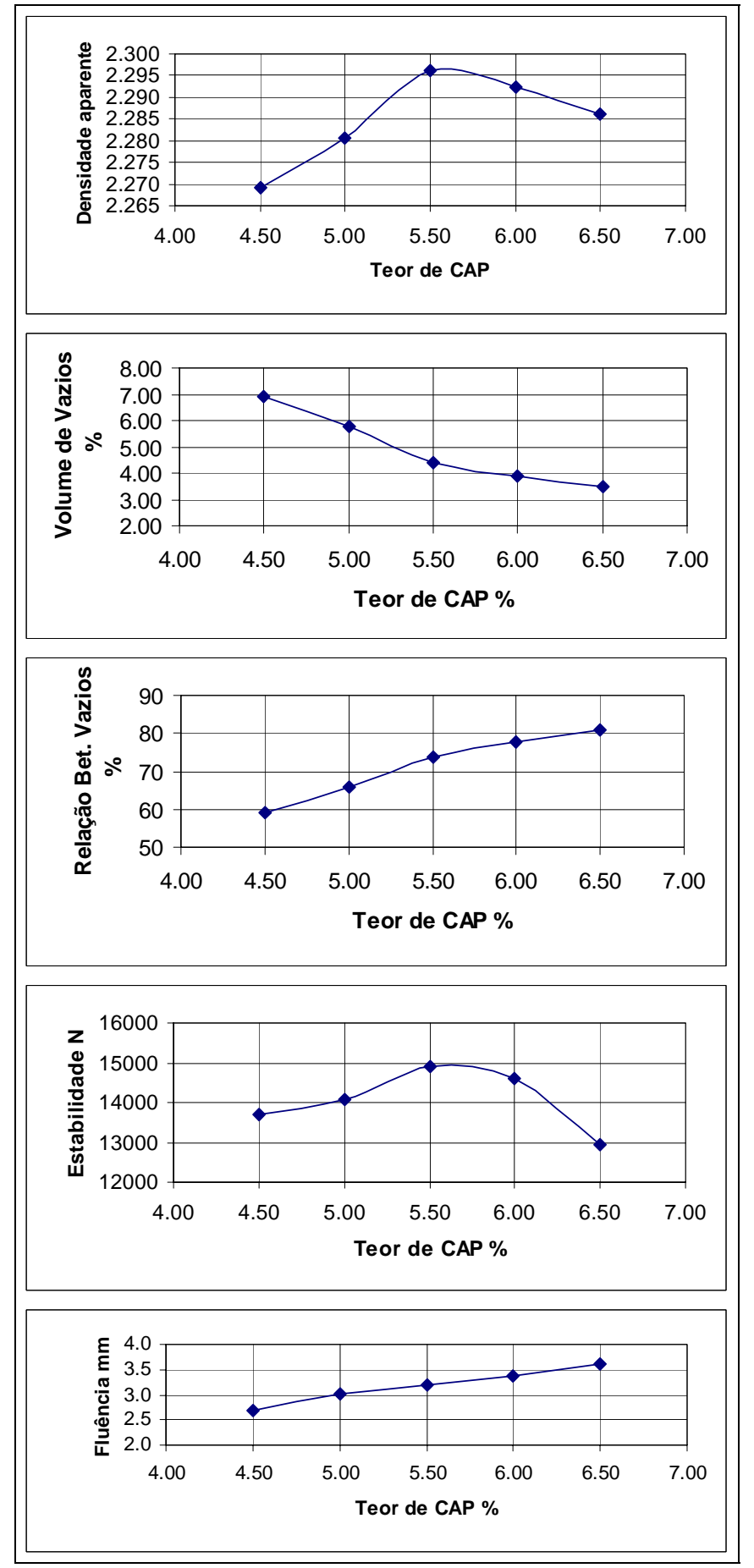

Figura I.3: Curvas da dosagem Marshall do Granito.

Tabela I.3: Dados da dosagem do Granito e CAP 20.

\begin{tabular}{cccccc}
\hline Teor CAP & Densidade aparente & Estabilidade.(N) & Fluência (mm) & Vv (\%) & RBV (\%) \\
\hline 4,50 & 2,269 & 13712 & 2,7 & 6,90 & 59,21 \\
5,00 & 2,281 & 14083 & 3,0 & 5,75 & 66,04 \\
5,50 & 2,296 & 14916 & 3,2 & 4,42 & 73,73 \\
6,00 & 2,292 & 14612 & 3,4 & 3,89 & 77,62 \\
6,50 & 2,286 & 12956 & 3,6 & 3,47 & 80,77 \\
\hline
\end{tabular}


APÊNDICE II: RESULTADOS DOS ENSAIOS DE MÓDULO DE RESILIÊNCIA NAS TEMPERATURAS DE $10,25 \mathrm{E} 40^{\circ} \mathrm{C}$ 


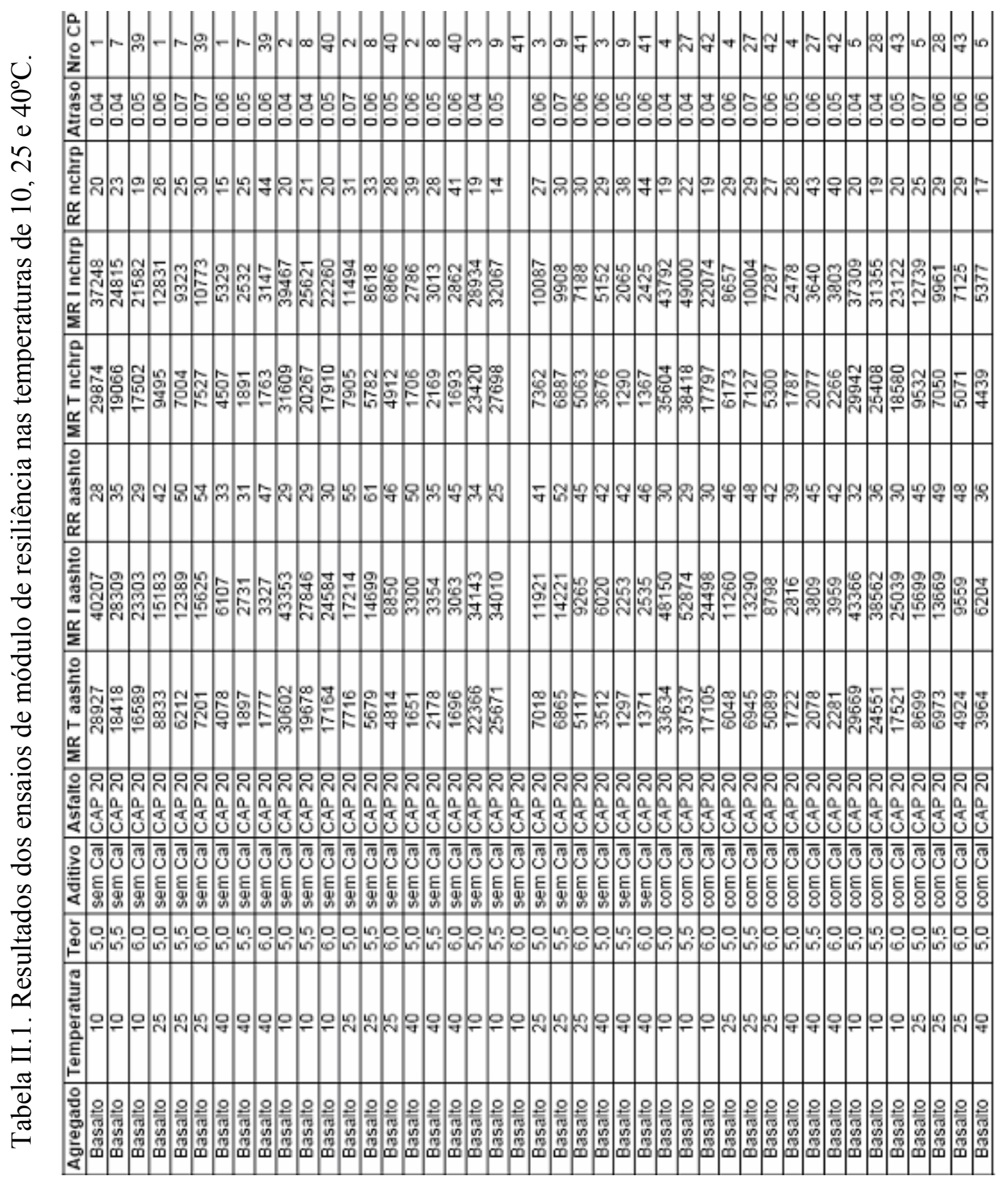




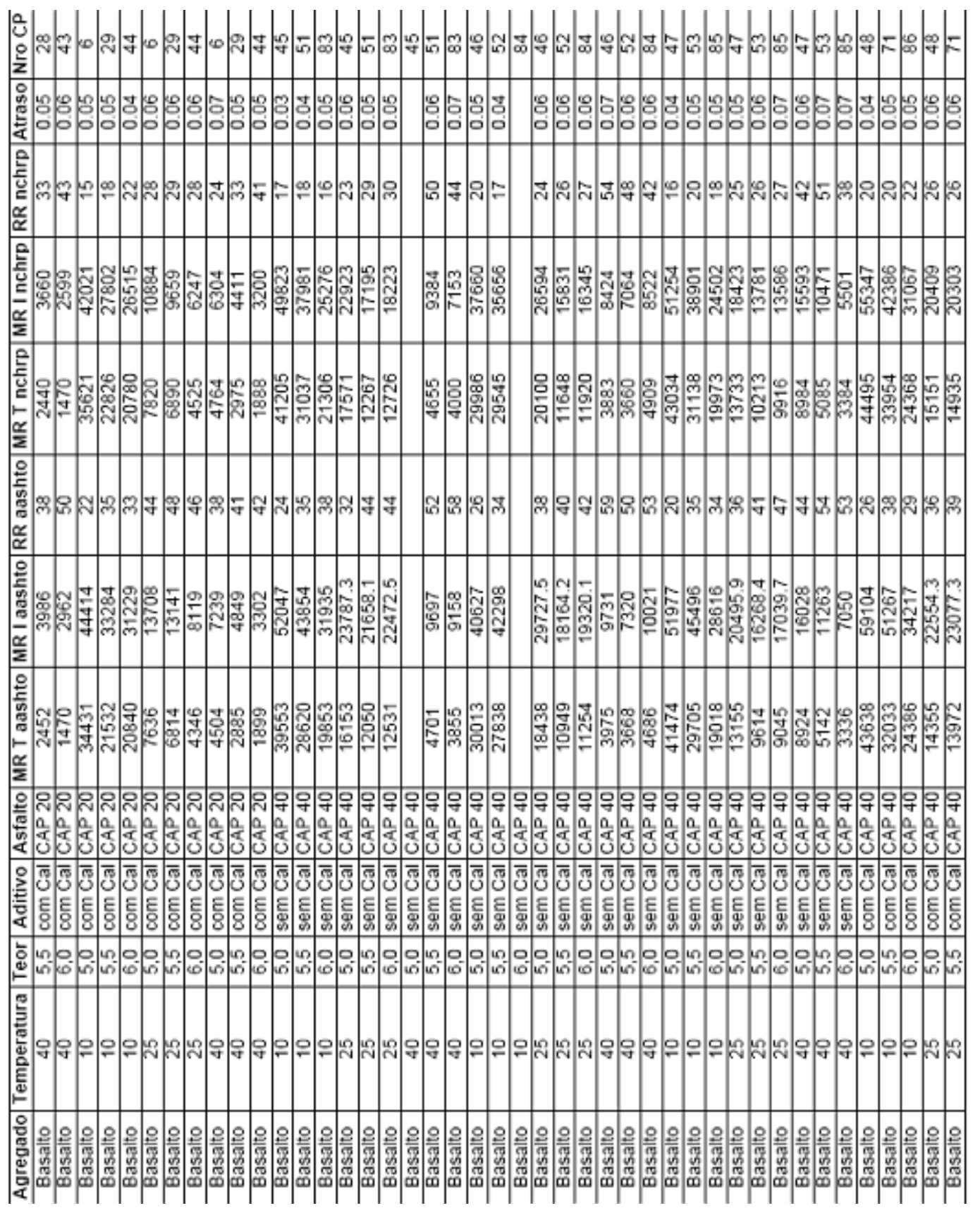




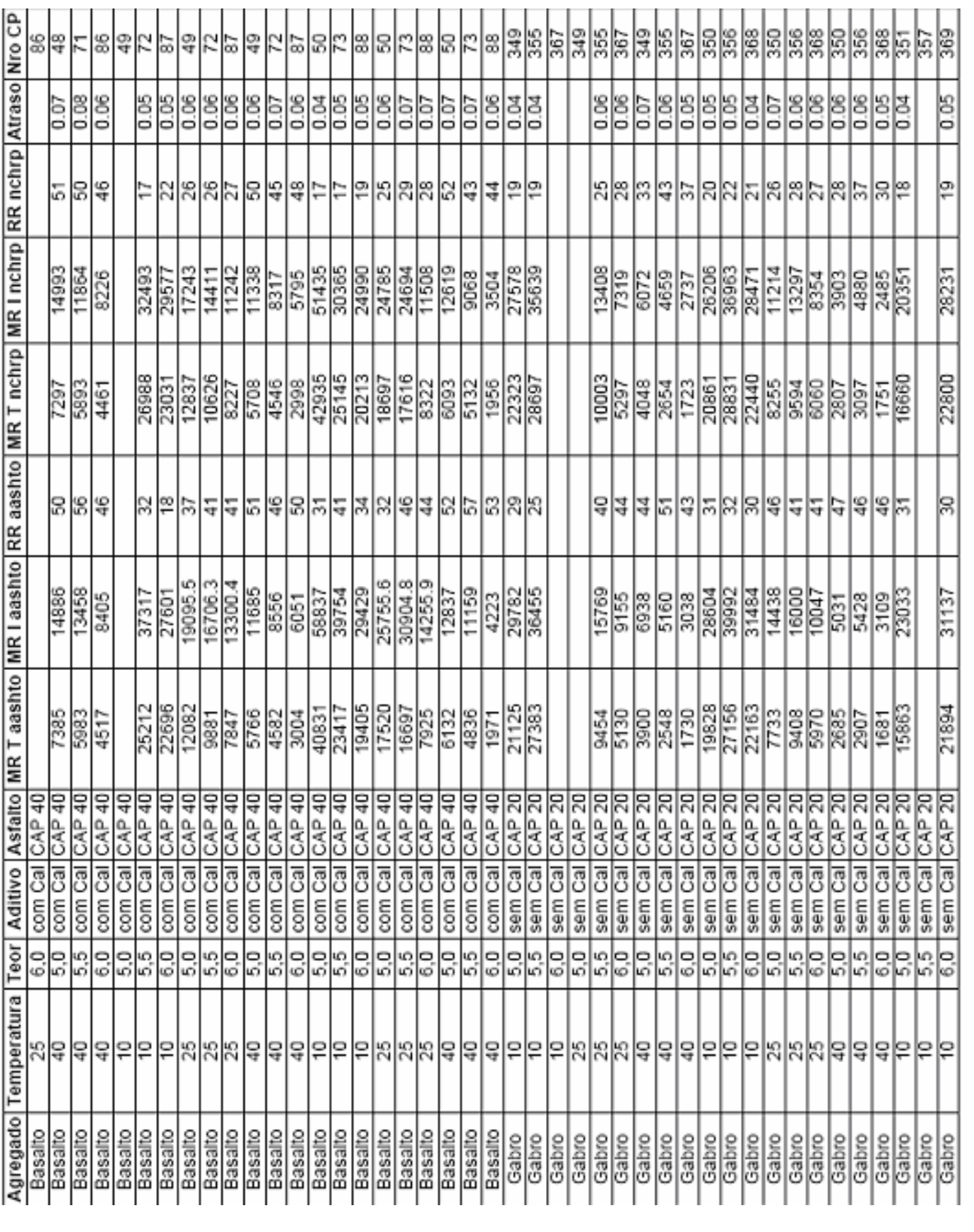




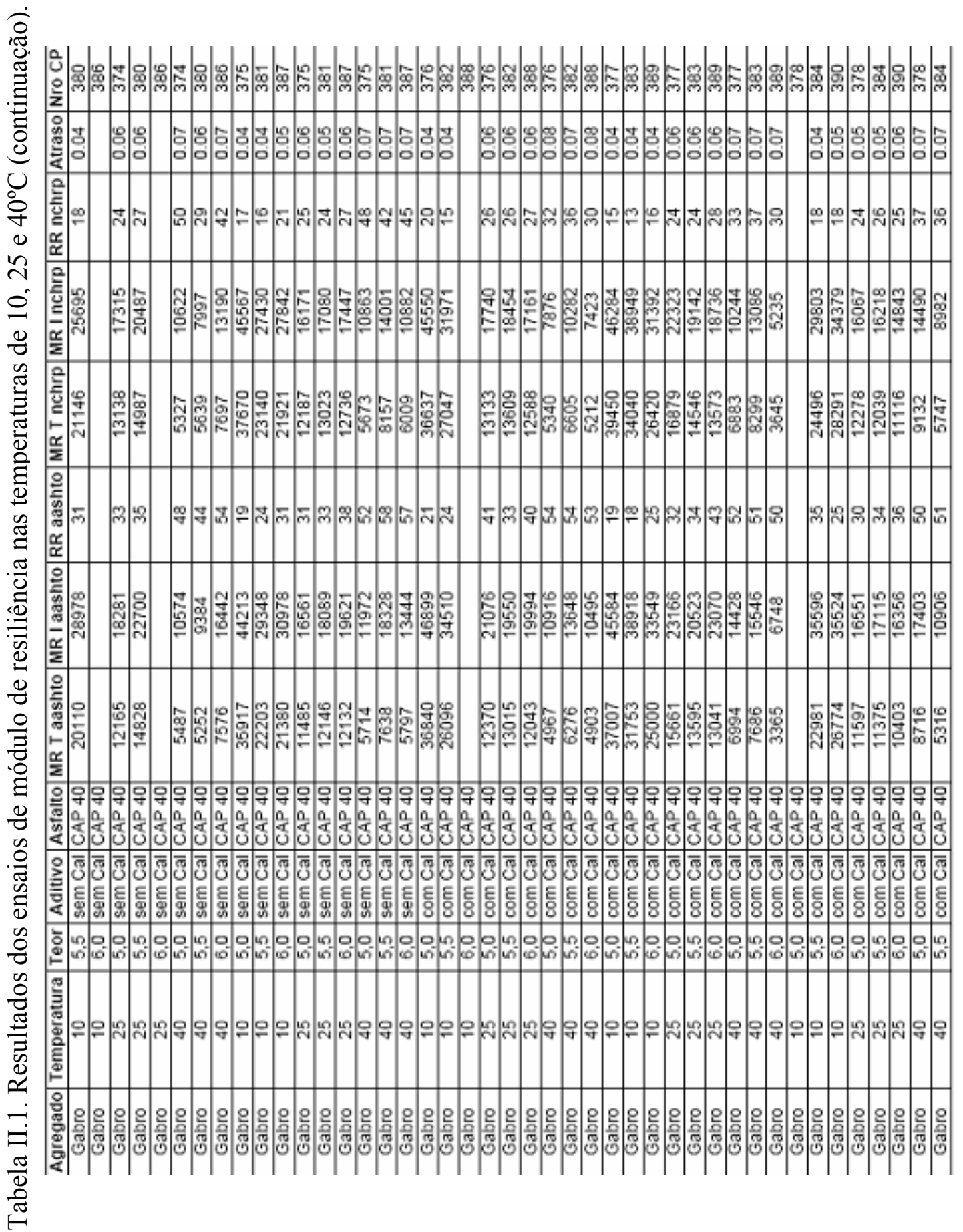




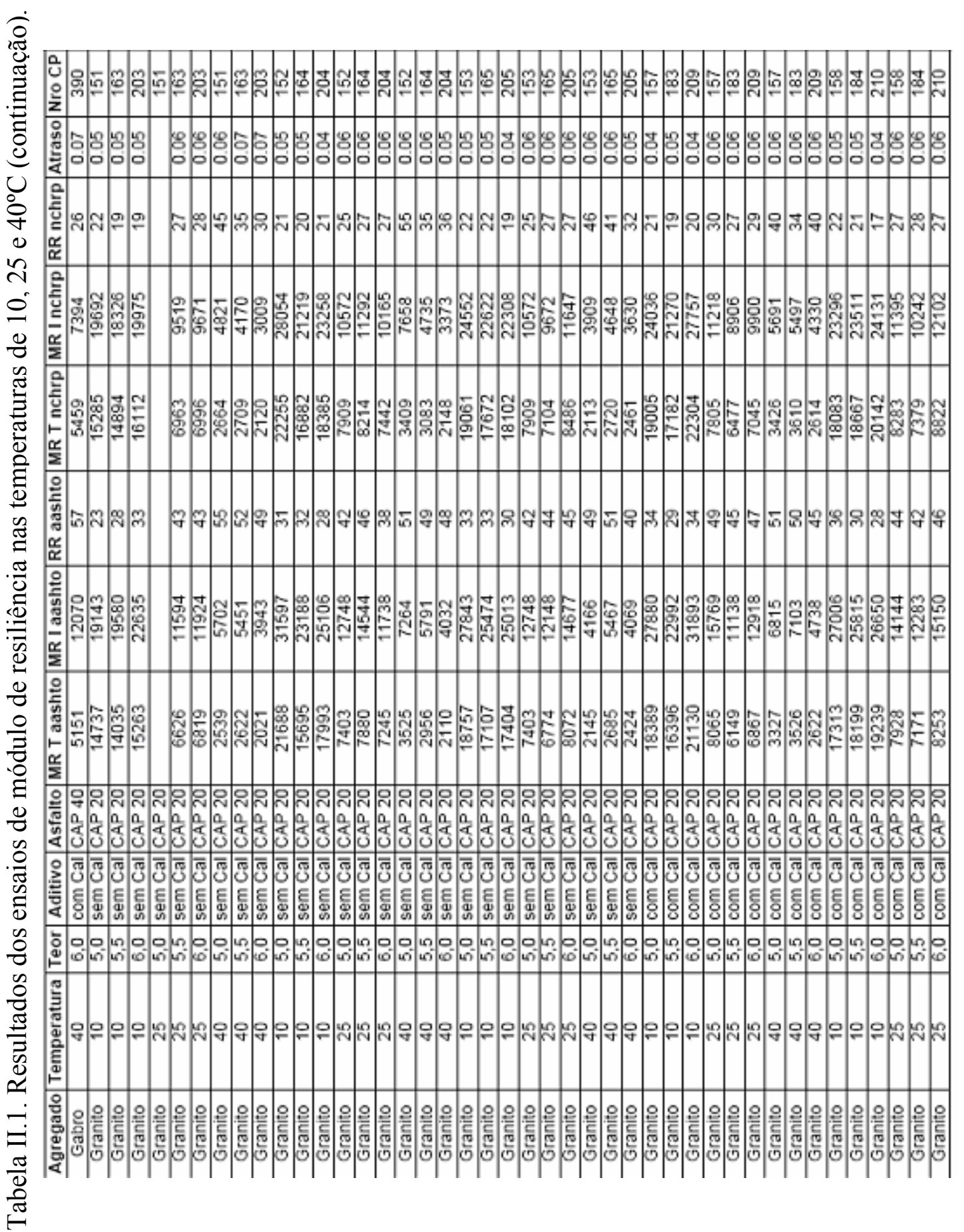




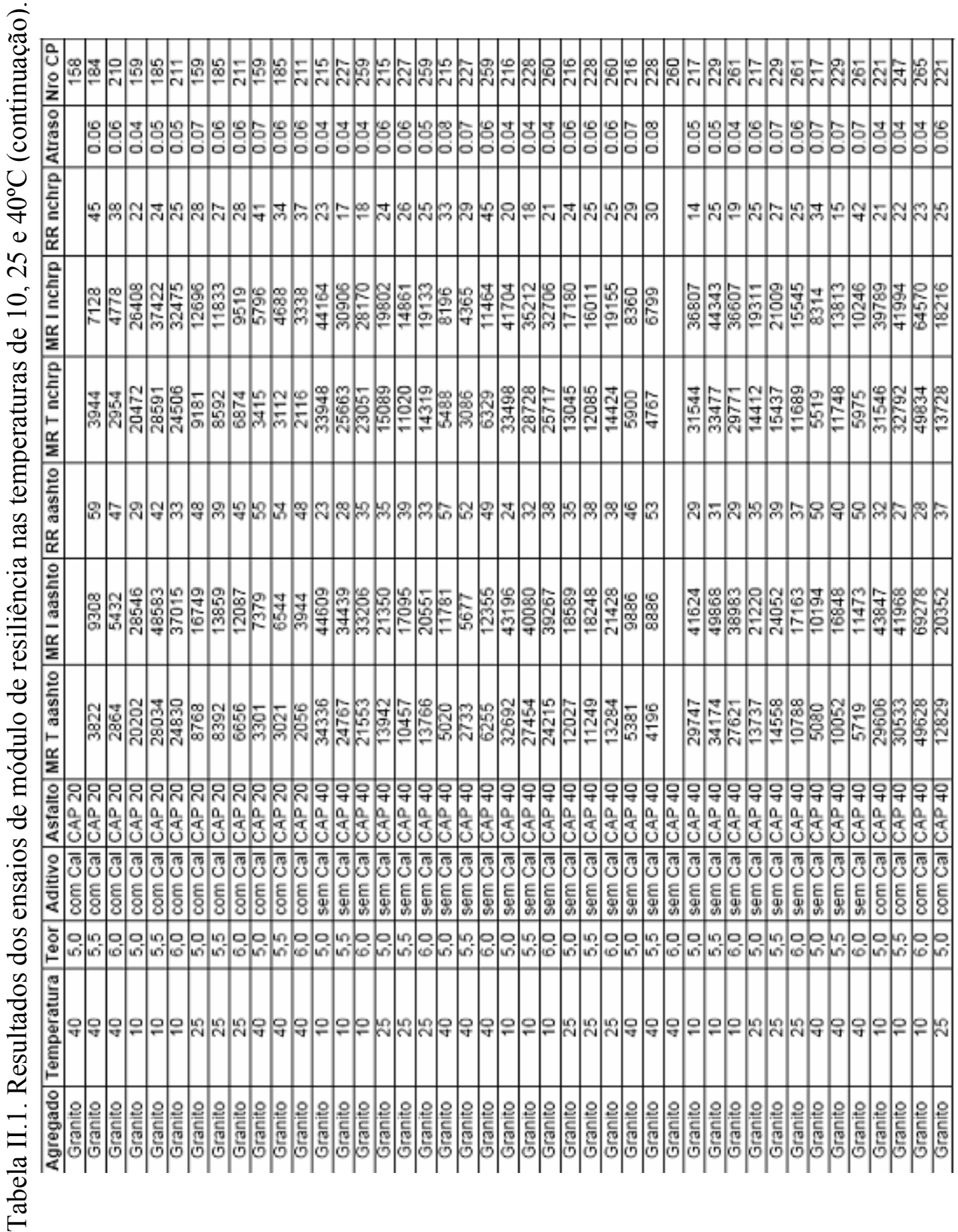




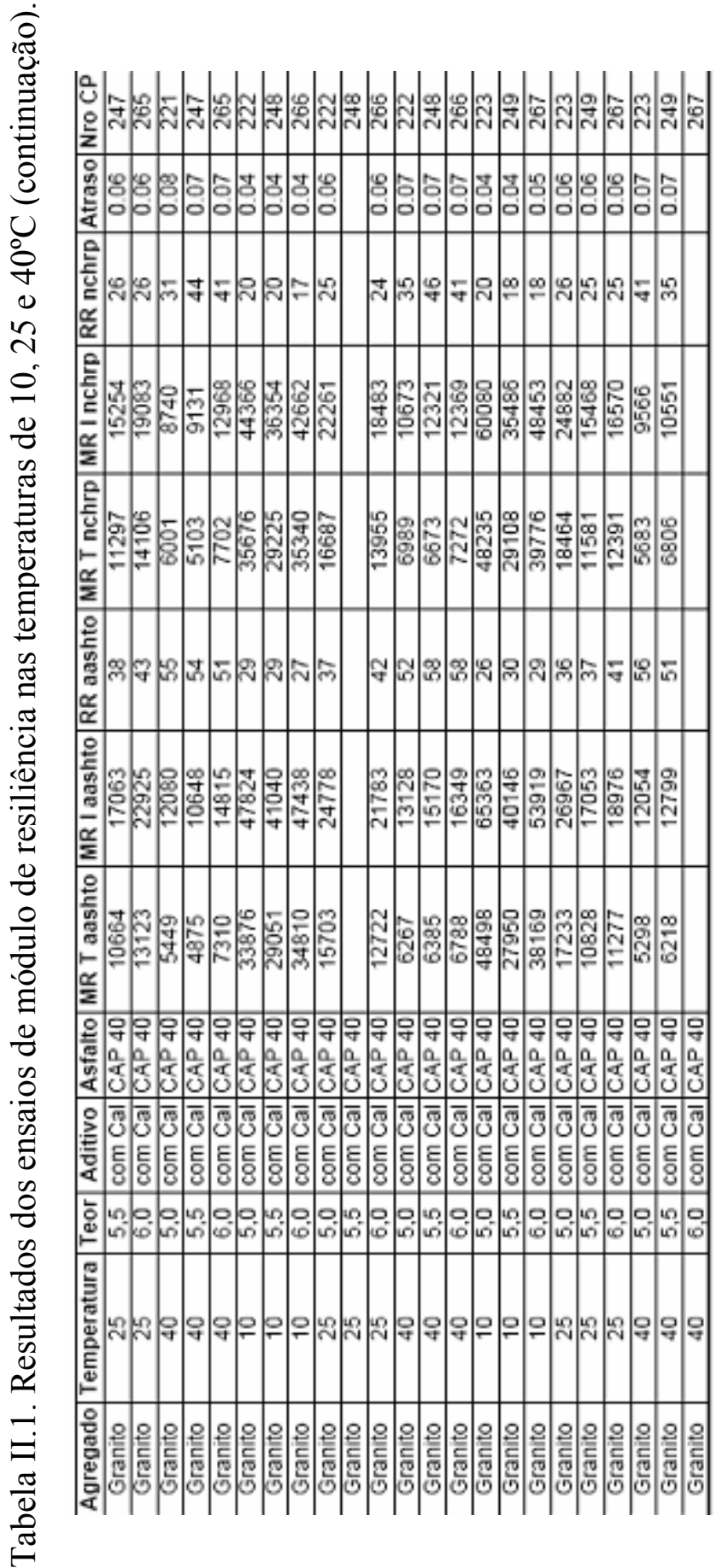


APÊNDICE III: RESULTADOS DOS ENSAIOS DE MÓDULO DE RESILIÊNCIA E RESISTÊNCIA À TRAÇÃO À $25^{\circ} \mathrm{C}$ 


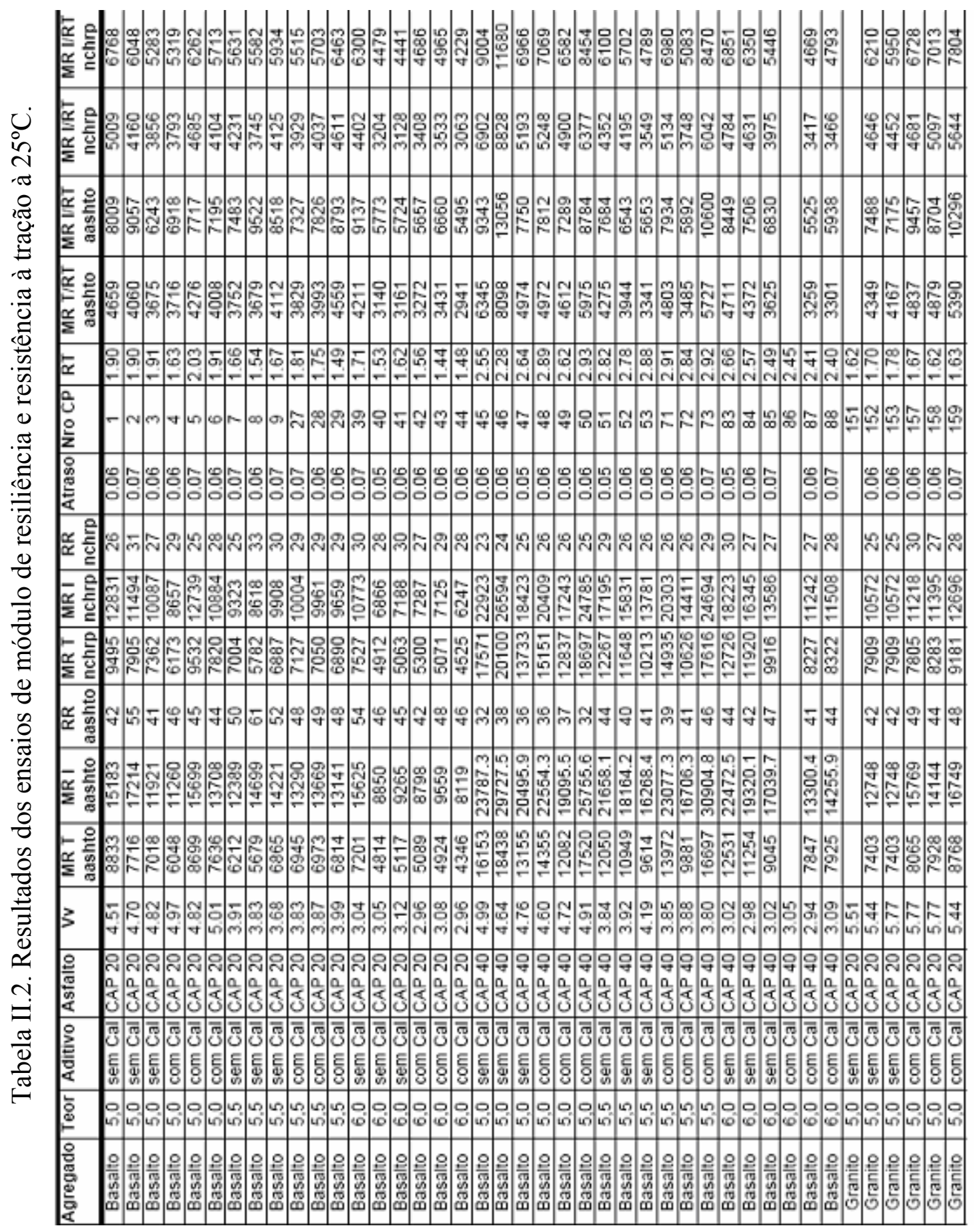




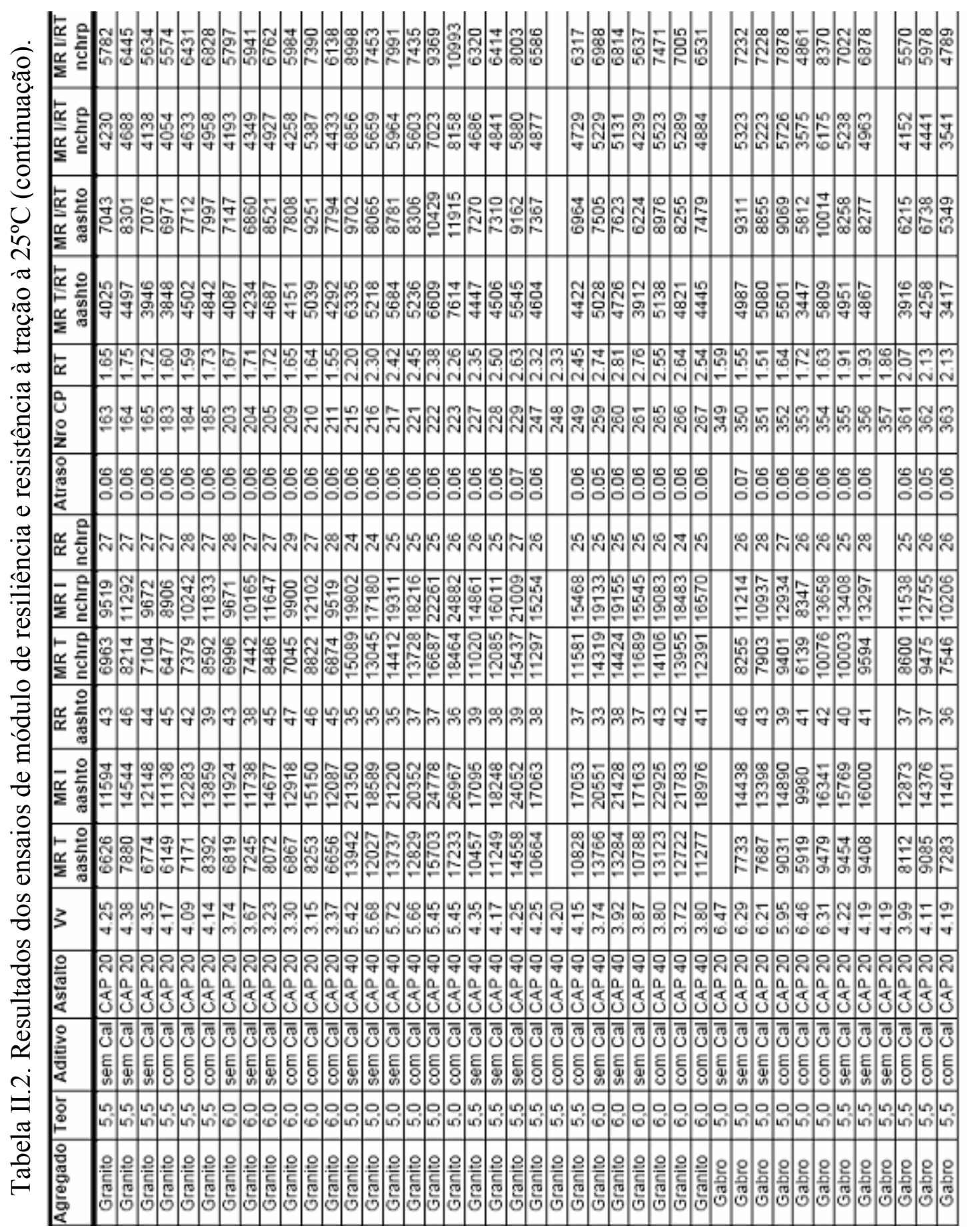




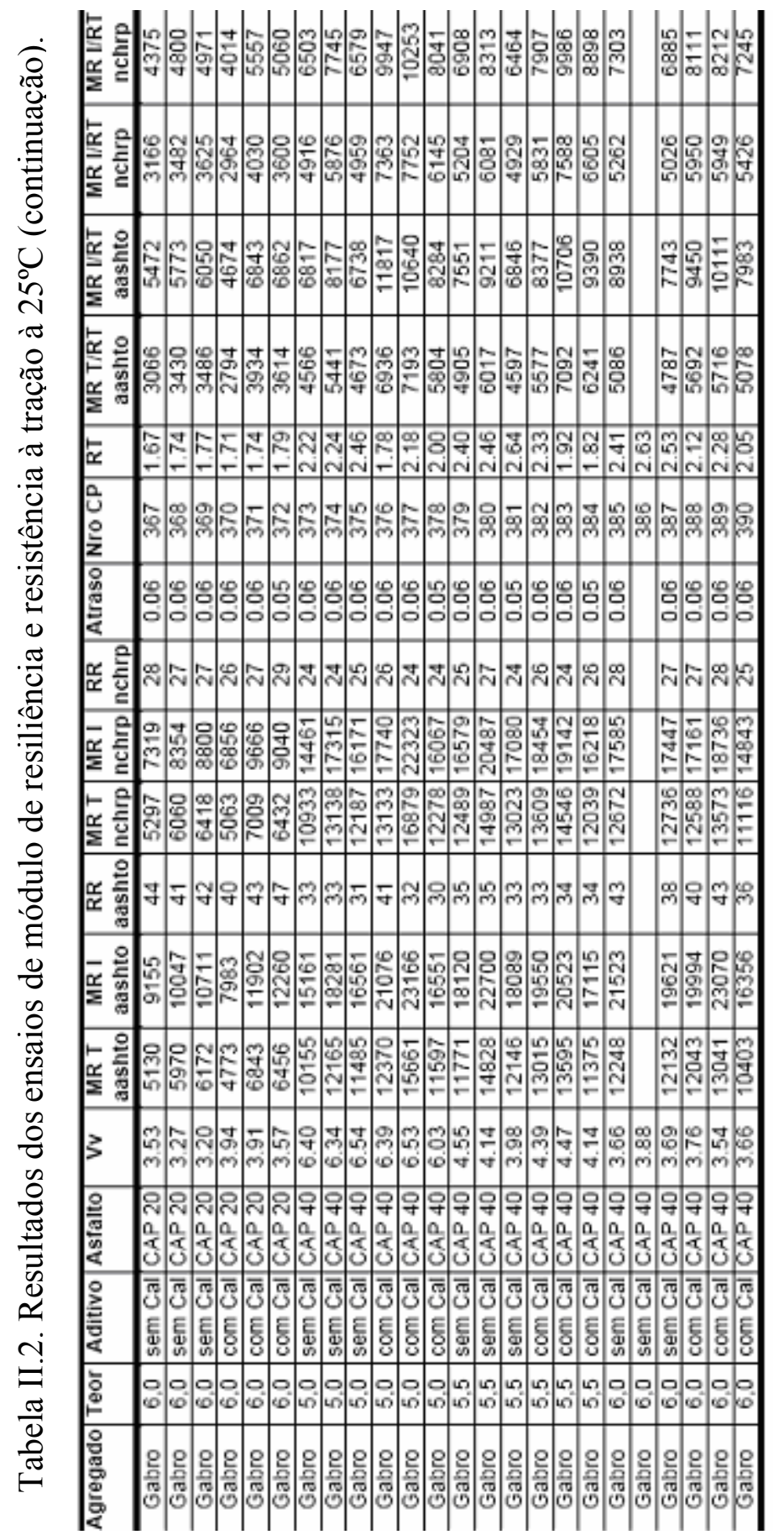


ANEXO A: ALGORITMO DAS REGRESSÕES PARA O CÁLCULO DO DESLOCAMENTO RESILIENTE INSTANTÂNEO 
1. Esquema do algoritmo para determinação do deslocamento resiliente instantâneo segundo a pesquisa NCHRP 1-28/1-28A

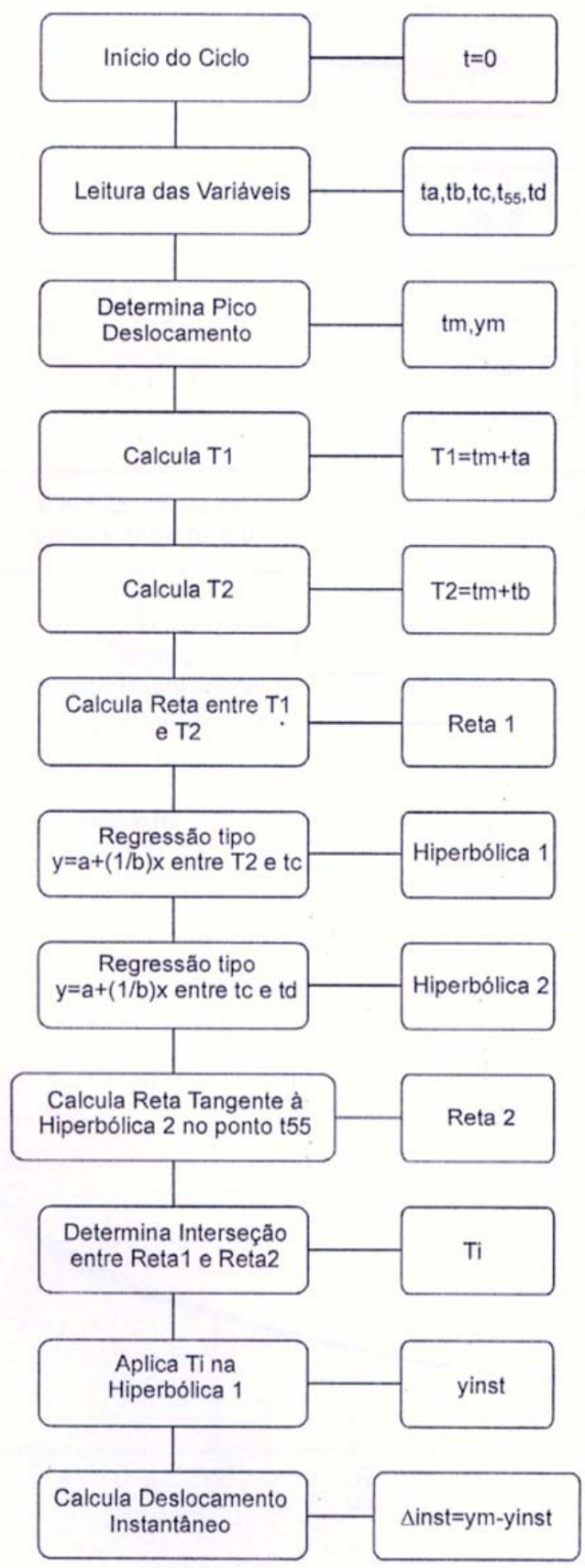


2. Esquema do algoritmo para determinação do deslocamento resiliente total segundo a pesquisa NCHRP 1-28/1-28A

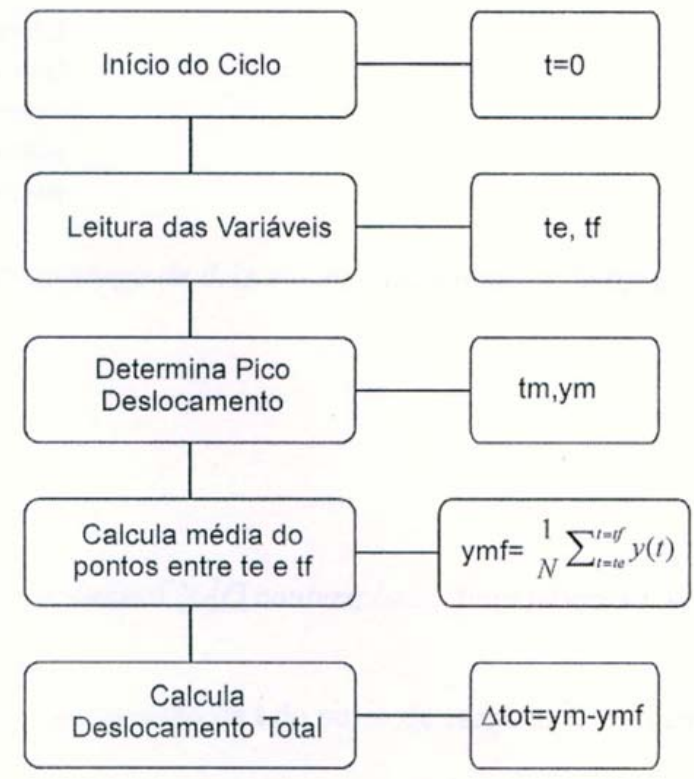

\section{Referências no pulso de deslocamento}

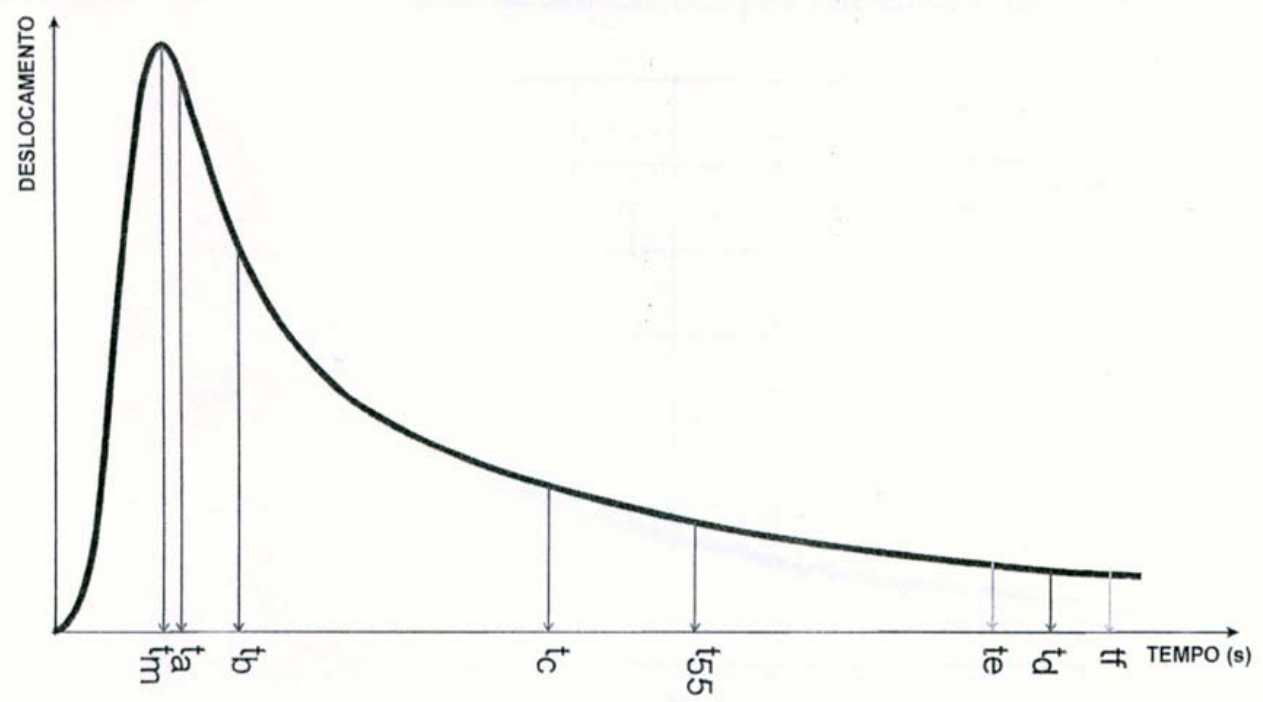


4. Recomendações dos tempos para determinação dos deslocamentos resilientes segundo a pesquisa NCHRP 1-28/1-28A

- $\mathrm{t}_{\mathrm{c}}=40 \%$ rest period

- $t_{d}=90 \%$ rest period

- $\mathrm{t}_{55}=55 \%$ rest period

- $\mathrm{t}_{\mathrm{e}}=85 \%$ rest period

- $\mathrm{t}_{\mathrm{f}}=95 \%$ rest period

$\rightarrow$ Considerando pulso de carga de 0,1s e tempo de descanso de 0,9s, vem:

- $\mathrm{t}_{\mathrm{c}}=0,46$

- $\mathrm{t}_{\mathrm{d}}=0,91 \mathrm{~s}$

- $\mathrm{t}_{55}=0,595 \mathrm{~s}$

- $\mathrm{t}_{\mathrm{e}}=0,865 \mathrm{~s}$

- $\mathrm{t}_{\mathrm{f}}=0,955 \mathrm{~s}$

$\rightarrow$ Recomendação para os tempos $\underline{\text { NAO }}$ contemplados pela pesquisa NCHRP 1-28/1-28A

- $\mathrm{t}_{\mathrm{a}}=0,005+\mathrm{t}_{\mathrm{m}}$

- $\mathrm{t}_{\mathrm{b}}=\mathrm{t}_{\mathrm{m}}+1 / 2 \mathrm{t}_{\text {pulso de carga }}$ (no caso de $\mathrm{t}$ do pulso de carga de $0,1 \mathrm{~s}$, vem: $\mathrm{t}_{\mathrm{b}}=\mathrm{t}_{\mathrm{m}}+0,05$ )

\section{Exemplo de cálculo}

i. Separação das porções do pulso de deslocamento para determinação das regressões.

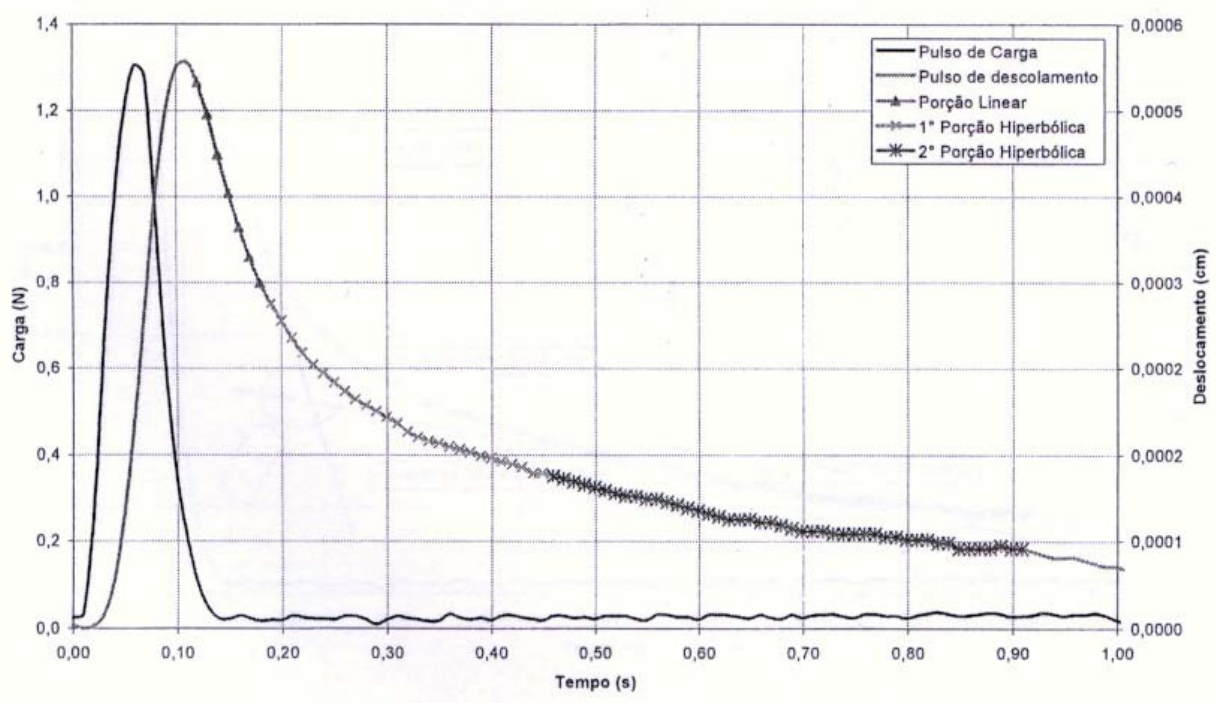


ii. Determinação das retas de regressões (1 regressão linear e 2 regressões hiperbólicas).

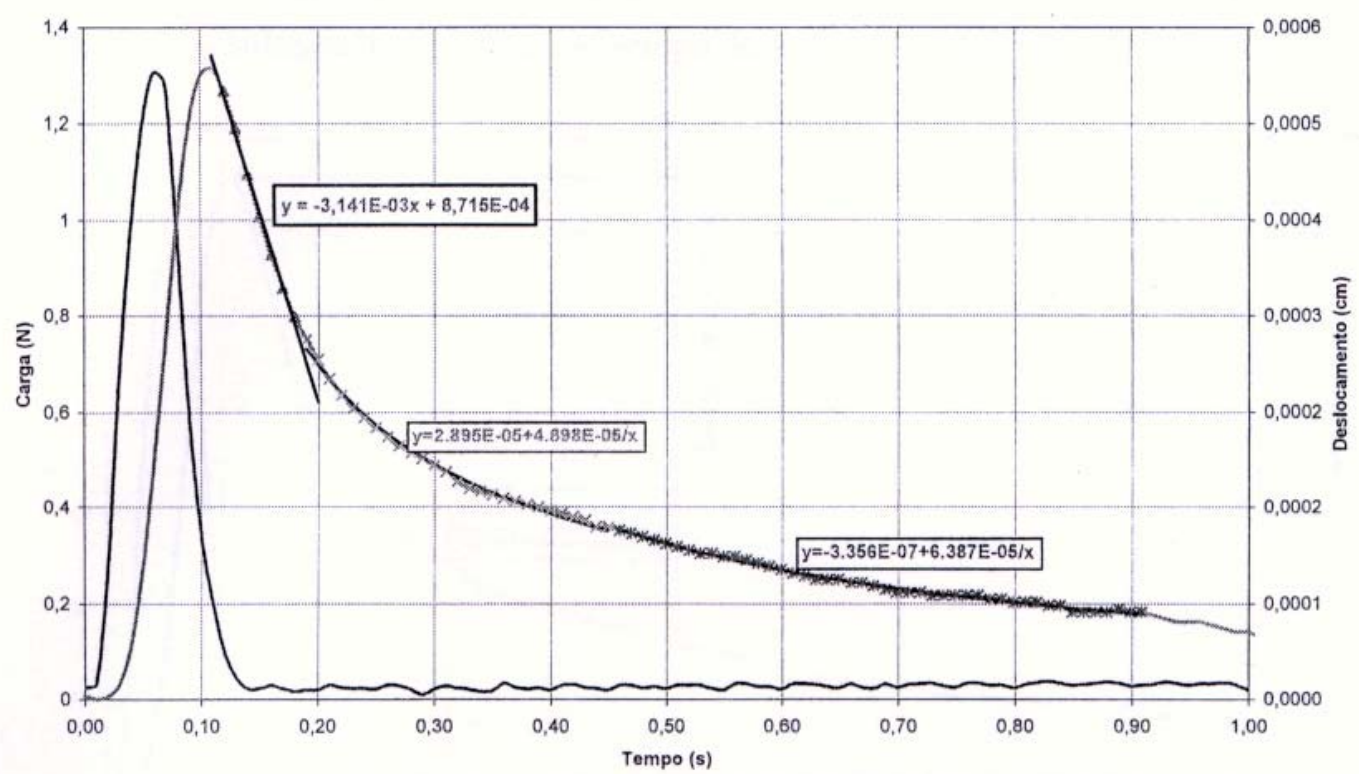

iii. Determinação da reta tangente à regressão hiperbólica 2 no ponto correspondente a $55^{\circ}$, período de descanso, e determinação do tempo correspondente à interseção desta com a re regressão linear (interseção*).

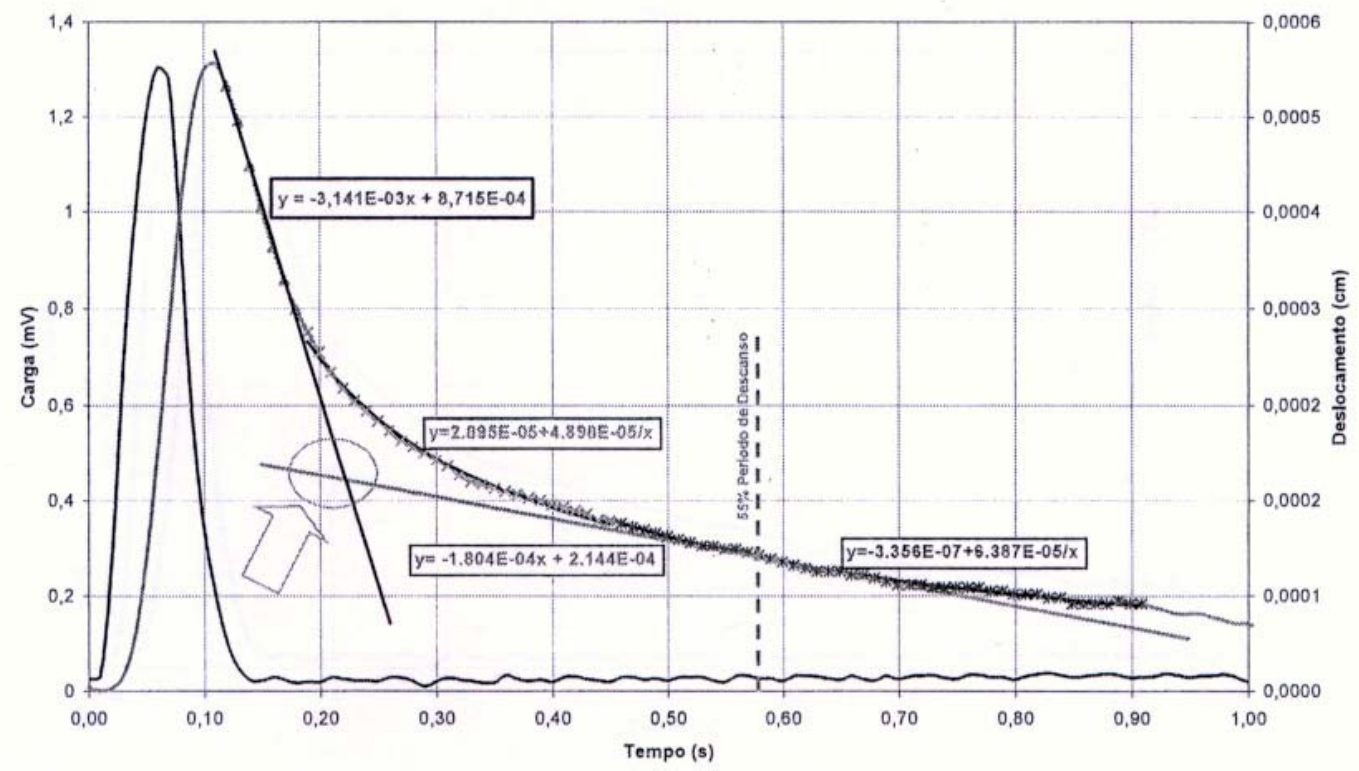


iv. Determinação do deslocamento instantâneo - diferença entre o ponto de máximo deslocamento pela ordenada resultante da aplicação do tempo de interseção* na regressão hiperbólica 1.

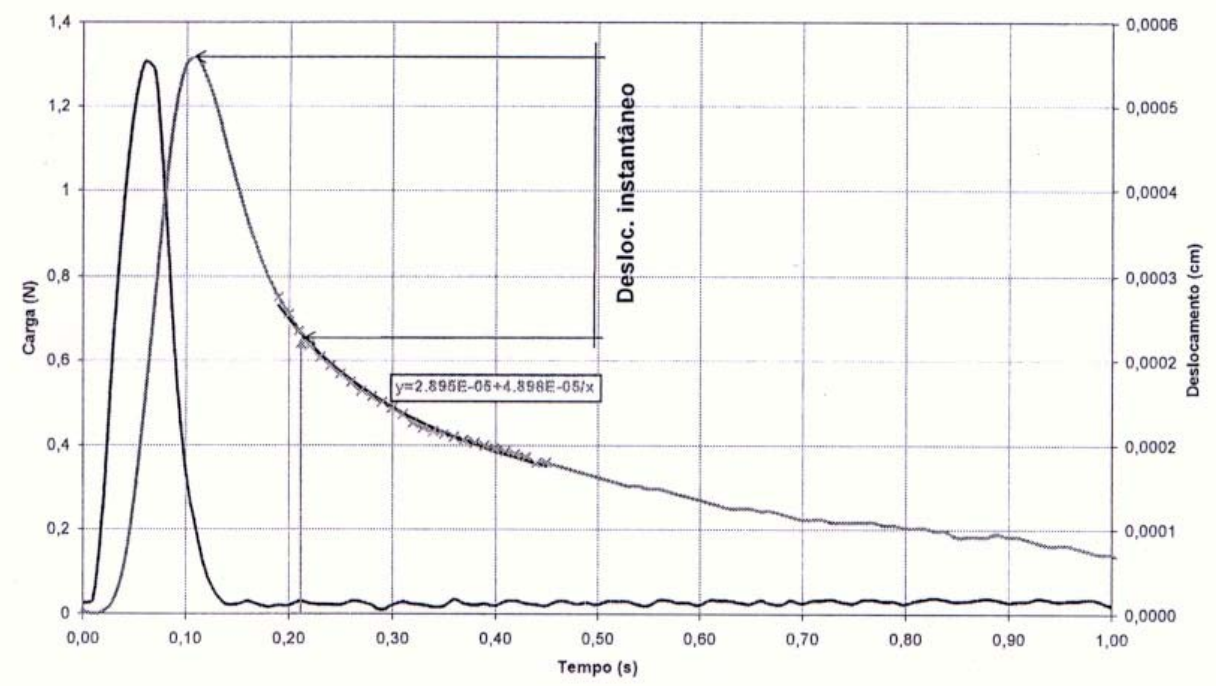

v. Determinação do deslocamento total através da diferença entre o ponto de máximo deslocamento e a ordenada média resultante da porção relativa à $85 \%$ - 95\% do período de descanso.

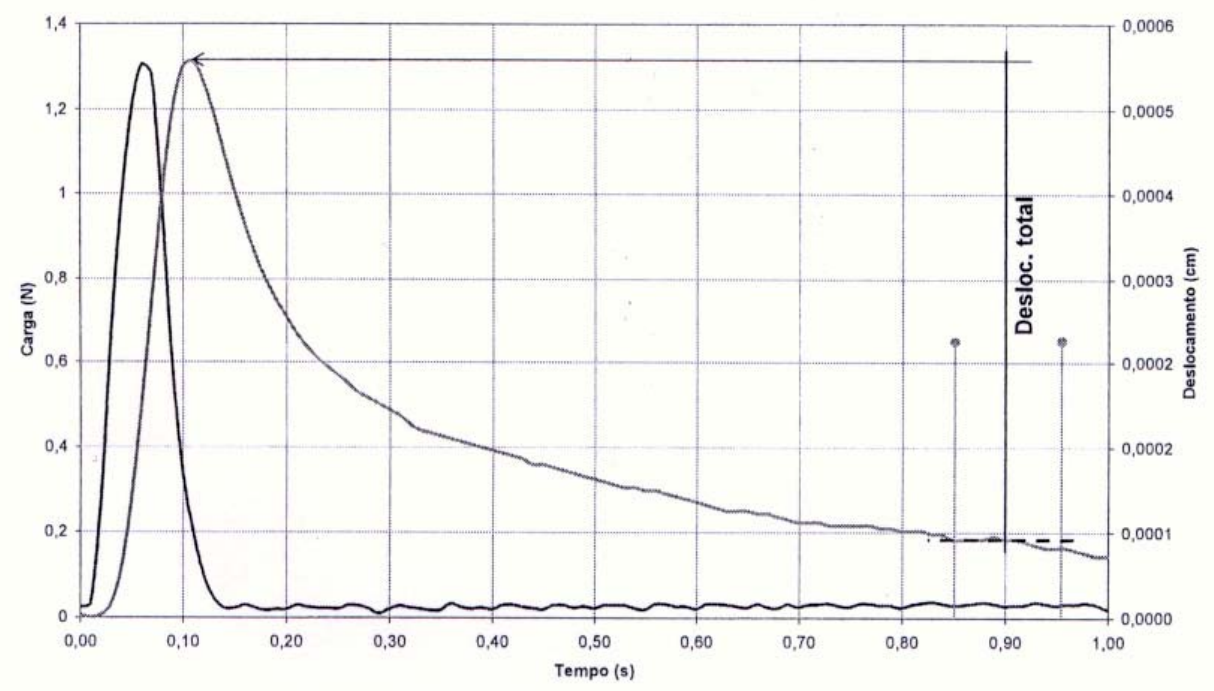

